\author{
Monograph \\ urn:1sid:zoobank.org:pub:623BBCE3-12A5-45A9-802A-2ED2E15164A3
}

\title{
Porifera from Ponta do Ouro (Mozambique)
}

\author{
Barbara CALCINAI ${ }^{1, *}$, Giuseppe BELFIORE ${ }^{2}$, Daniela PICA ${ }^{3}$, Fabrizio TORSANI ${ }^{4}$, \\ Marco PALMA ${ }^{5} \&$ Carlo CERRANO ${ }^{6}$

\begin{abstract}
The diversity of Porifera from Ponta do Ouro (Mozambique) has been evaluated; this paper presents the first taxonomic effort devoted to sponges in the area, while studies of closeby areas are quite dated. Overall, 55 specimens were examined, leading to 26 described species; among these, four are new (Hyattella sulfurea Calcinai \& Belfiore sp. nov., H. pedunculata Calcinai \& Belfiore sp. nov., Amphimedon palmata Calcinai \& Belfiore sp. nov. and Phoriospongia mozambiquensis Calcinai \& Belfiore sp. nov.) and four (Chondrosia corticata Thiele, 1900, Callyspongia (Cladochalina) aerizusa Desqueyroux-Faundez, 1984, Clathria (Thalysias) hirsuta Hooper \& Levi, 1993 and Ciocalypta heterostyla Hentschel, 1912) are new records for the Indian Ocean. For Callyspongia (Euplacella) abnormis Pulitzer-Finali, 1993, Callyspongia (Callyspongia) pulitzeri Van Soest \& Hooper, 2020 and Amphimedon brevispiculifera (Dendy, 1905) this represents the first record after their initial discovery. The majority of the species have a wide distribution in the Indo-Pacific Ocean, but species from South and East Africa have also been recorded. These data highlight the characteristic of Ponta do Ouro as a transitional zone, located between a tropical and temperate biogeographic province, as well as the importance of increasing biodiversity knowledge of this biogeographic border to monitor possible shifts in the area as a consequence of climate crisis.
\end{abstract}

Keywords. Marine biodiversity, new species, new records, Indian Ocean.

Calcinai B., Belfiore G., Pica D., Torsani F., Palma M. \& Cerrano C. 2020. Porifera from Ponta do Ouro (Mozambique). European Journal of Taxonomy 698: 1-56. https://doi.org/10.5852/ejt.2020.698 


\section{Introduction}

The south of Mozambique, where Ponta do Ouro is located, is a unique ecosystem characterized by a high biodiversity. This richness depends on different factors such as the physical water parameters, the high mass of nutrients, the complexity of the environment and, especially, the presence of coral reefs (Pereira et al. 2014). Strong southeast trade winds have an impact on the climatic conditions, with cyclones in the south and monsoon in the north of the area (Pereira et al. 2014). The area is characterized by a water temperature with an annual average of $25^{\circ} \mathrm{C}$, thanks to the Agulhas Current (Pereira et al. 2014); this fact allows the development of coral reef ecosystems that are among the highest latitude coral reefs in the world. Moreover, the Ponta do Ouro coast belongs to the tropical Delagoa ecoregion in the Western Indian Ocean Province (Spalding et al. 2007), which is characterized by a high endemism and diversity. Due to its natural richness and beauty, the south of Mozambique is under review by UNESCO as a potential World Heritage Site. Moreover, it has been classified as an important biodiversity site within the Eastern African Marine Ecoregion (Guerreiro et al. 2011).

The area of Ponta do Ouro town (Fig. 1) is quickly developing, and this could be associated with consequent threats, such as overfishing, coastal modification, natural resources exploitation, or unregulated and damaging tourism practices (Olson 2010). In order to preserve the biodiversity of the area, the government declared a partial protected marine area (PPMRPO) of $678 \mathrm{~km}^{2}$ on 14 July 2009, stretching from Ponta do Ouro in the south to the Maputo River Mouth in Maputo Bay, in the north (Fig. 1).

The Ponta do Ouro reef system is classified as a patch reef and occupies an area of about $5 \mathrm{~km}^{2}$ among the estimated $1900 \mathrm{~km}^{2}$ of the reef area in Mozambique (PPMR 2009). From the Bazaruto archipelago $\left(21^{\circ} 74^{\prime} \mathrm{S}, 35^{\circ} 42^{\prime} \mathrm{E}\right)$ to Ponta do Ouro $\left(26^{\circ} 84^{\prime} \mathrm{S}, 32^{\circ} 89^{\prime} \mathrm{E}\right)$, the coral reef grows on sandstone, which originates from submerged fossil coastal sand dunes; fully formed reefs originating from biogenic accretion do not occur here (Pereira et al. 2014; Palma et al. 2019).

In terms of abundance, the main colonizing organisms are soft corals followed by hard corals (Daly et al. 2013). The coverage of live coral in Ponta do Ouro is between $33.3 \%$ and $35.5 \%$; rock and algae are the other dominant benthic categories (respectively $40.8 \%$ and $54.3 \%$ ) (Pereira et al. 2014). Reef species associated with the area include more than 900 species of fish (Pereira 2000), around 300 species of hard corals (Obura 2012) and more than 50 species of soft corals (Benayahu \& Shlagman 2003). Alcyonacean corals of the genera Sinularia May, 1898 and Lobophytum Marenzeller, 1886 dominate the soft coral community, while the hard-coral community is represented by Scleractinian of genera Acropora Oken, 1815 and Montipora Blainville, 1830 (PPMR 2009). Other taxa such as invertebrates, ascidians (Daly et al. 2013) and sponges are poorly studied.

This is the first taxonomic work about the sponges of Mozambique's coast, while studies of closeby areas are quite dated: Madagascar (Lévi 1956); Mambone, Paradise Island and Inhaca Island (Lévi 1964; Thomas 1979), Europe Island and the Grand Recif de Tolaria (Vacelet \& Vasseur 1965, 1971; Vacelet et al. 1976) and East Africa (Pulitzer-Finali 1993). More recently, a sponge assemblage in the Quirimba Archipelago has been studied for the north of Mozambique and another one from Inhaca Island for the south of Mozambique (Barnes \& Bell 2002) and, quite close to the sampling area, in Sodwana Bay, the eastern part of South Africa (Samaai et al. 2019).

The aim of this work is the study of the diversity of the Phylum Porifera in the Area of Ponta do Ouro (Mozambique). This study is part of a wider research, the European project "Green Bubbles", whose scope is to discover new local peculiarities that may support the development of new cultural interests for recreational divers and trigger sustainable paths for diving tourism. 


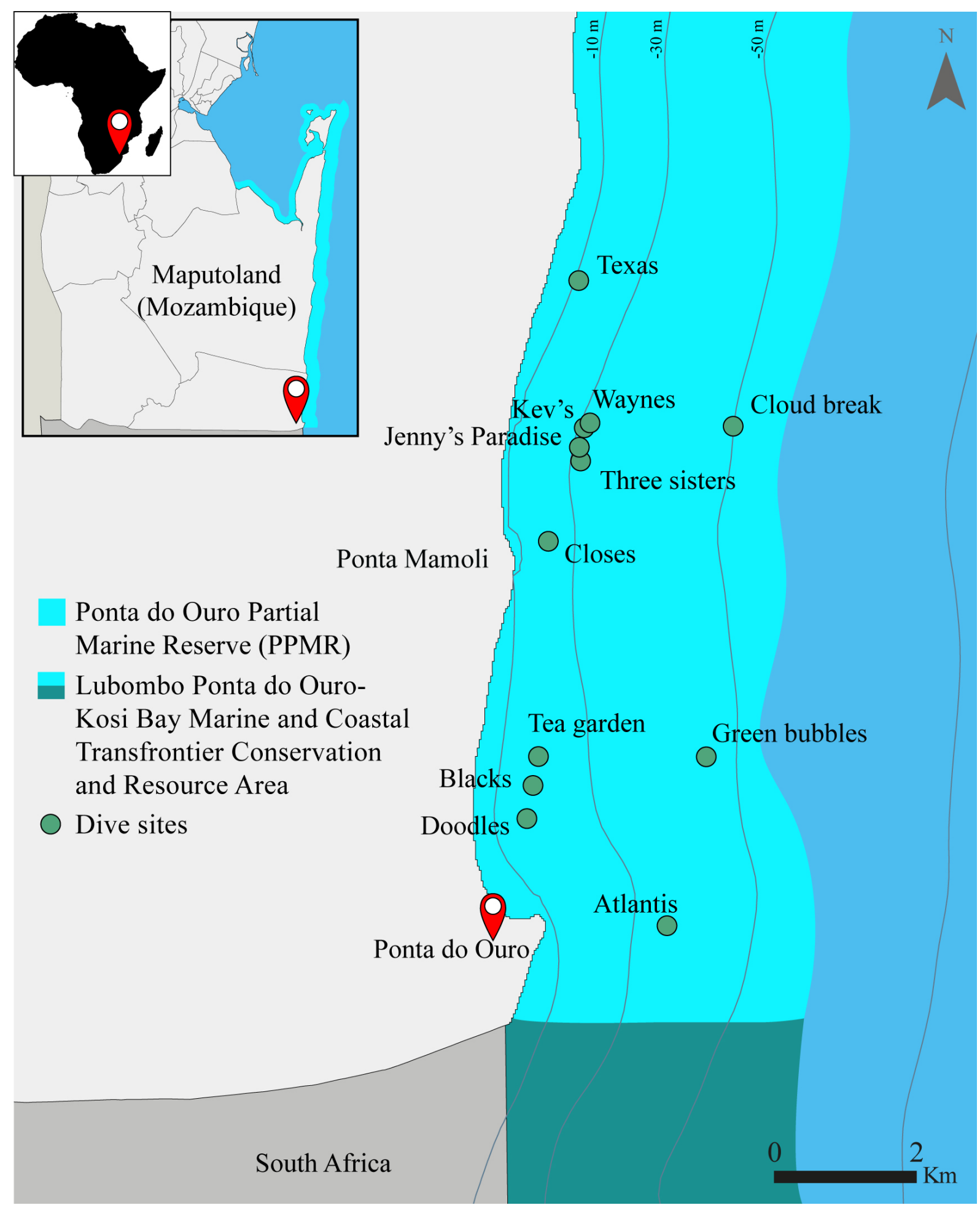

Fig. 1. Map of the coast of Mozambique where Ponta do Ouro, the partial Marine Reserve and dive sites for sampling are located. 


\section{Material and methods}

The studied material was sampled during three expeditions conducted within the "Green Bubbles" project in May and November 2015 and in February 2017. Specimens were collected at shallow depths by scuba divers in several sites in Ponta do Ouro (Fig. 1) (Permit $n^{\circ}$ 09/2018 ANAC); the live sponges were photographed and the samples conserved dried or in $70^{\circ}$ alcohol.

The specific data are reported in Appendix 1, such as the kind of conservation, sites and depths of the sampling.

In order to analyze the spicules according to Rützler (1978), small portions of the samples were treated with nitric acid at $65 \%$ and washed twice with $70^{\circ}$ alcohol before being fixed on slides with the mounting medium Eukitt. Thick sections were made for studying the skeleton organization, according to Hooper (2000). The sections were then treated with Bioclear and mounted with Eukitt on microscopic slides. For sponges without siliceous spicules and with spongin fibers, sodium hypochlorite in a water solution was utilized to clear the fibers from tissue, the digestion was blocked with $70^{\circ}$ alcohol, the skeletons subsequently mounted on slides and analyzed with an optical microscope. For scanning electron microscope (SEM) analysis (Philips XL20), the samples were first cut, then melted with nitric acid at $65 \%$ and washed twice with $70^{\circ}$ alcohol, after which a portion of this solution with the suspended spicules was dropped on the stub, which was, finally, coated with gold.

The dimensions of the spicules were taken with 15 measurements under an optical microscope with a magnification of 20 and $40 \times$ and are reported as minimum size, average size and standard deviation in brackets, and maximum size (e.g., min. length-(average length, standard deviation) - max. length $\times$ min. width-(average width, standard deviation)-max. width).

The type specimens are deposited in the Museo di Storia Naturale di Genova, Italy, labelled with the acronym MSNG. All the other collected material is indicated with the acronyms PO (Porifera) or PdO (Ponta do Ouro) or IMG (IMaGe) plus a number used by the collectors during the sampling. This additional material is deposited in the Museo di Storia Naturale di Genova, Italy; skeleton, spicule and histological preparations are located at the Università Politecnica delle Marche (first author's personal collection).

Slides with the types of Callyspongia (Euplacella) abnormis Pulitzer-Finali, 1993 (labelled MBA 167) and Callyspongia subtilis Pulitzer-Finali, 1993 (labelled KEN.59) were examined. This material was entrusted to the University of Genova (Department of Earth, Environmental and Life Sciences) by Pulitzer-Finali with the rest of his personal slide collection. The loan is not currently organized but preparations can be examined at the University of Genova, while Pulitzer-Finali's types are deposited at Museo di Storia Naturale di Genova, Italy.

In the present paper, we adopt the classification proposed in the Systema Porifera (Hooper \& Van Soest 2002) and the update by Morrow \& Cárdenas (2015).

\section{Results}

The 55 examined specimens resulted in the identification of 26 species belonging to 10 orders.

Four species (Hyattella sulfurea Calcinai \& Belfiore sp. nov., H. pedunculata Calcinai \& Belfiore sp. nov., Amphimedon palmata Calcinai \& Belfiore sp. nov. and Phoriospongia mozambiquensis Calcinai \& Belfiore sp. nov.) are new to science; Callyspongia (Euplacella) abnormis Pulitzer-Finali, 1993, Callyspongia (Callyspongia) pulitzeri Van Soest \& Hooper, 2020 and Amphimedon brevispiculifera (Dendy, 1905) were recorded for the first time since their original description. 
Chondrosia corticata Thiele, 1900, Callyspongia (Cladochalina) aerizusa Desqueyroux-Faundez, 1984, Clathria (Thalysias) hirsuta Hooper \& Levi, 1993 and Ciocalypta heterostyla Hentschel, 1912 are new records for the Indian Ocean.

\author{
Order Chondrosiida Boury-Esnault \& Lopes, 1985 \\ Family Chondrosiidae Schulze, 1877 \\ Genus Chondrosia Nardo, 1847
}

Chondrosia corticata Thiele, 1900

Fig. 2

Chondrosia corticata Thiele, 1900: 67, pl. 3 fig. 21.

\title{
Material examined
}

PONTA DO OURO - a single fragment of about $5 \times 2 \times 1.5 \mathrm{~cm} ; 26^{\circ} 49^{\prime} 17.512^{\prime \prime} \mathrm{S}, 32^{\circ} 53^{\prime} 42.521^{\prime \prime} \mathrm{E}$; Kev's; 23.4 m deep; 3 Feb. 2017; Cerrano leg.; PO7.

\section{Description}

The live sponge is massive (Fig. 2A). The large, protruding oscules in the live specimen (Fig. 2A), collapsed in the preserved sample. The color varies from dirty white to brown; the sides exposed are darker than other parts. The specimen preserved in alcohol shows the same color variation, with a lighter interior. The surface is smooth, with numerous foreign materials. The consistence of the sponge in spirit is soft and compressible. The fragment is cavernous with a thick cortex of about $0.7-2 \mathrm{~mm}$ (Fig. 2A-B), covering a soft pulpy choanosome, cream-colored (Fig. 2A).

\section{Remarks}

The absence of spicules and of an organic skeleton, the parameters usually used to discriminate sponge species, makes it difficult to distinguish between species of Chondrosia Nardo, 1847 leading some scientists to consider certain species such as $C$. reniformis (the type species of the genus) as cosmopolitan (Lazoski et al. 2001).
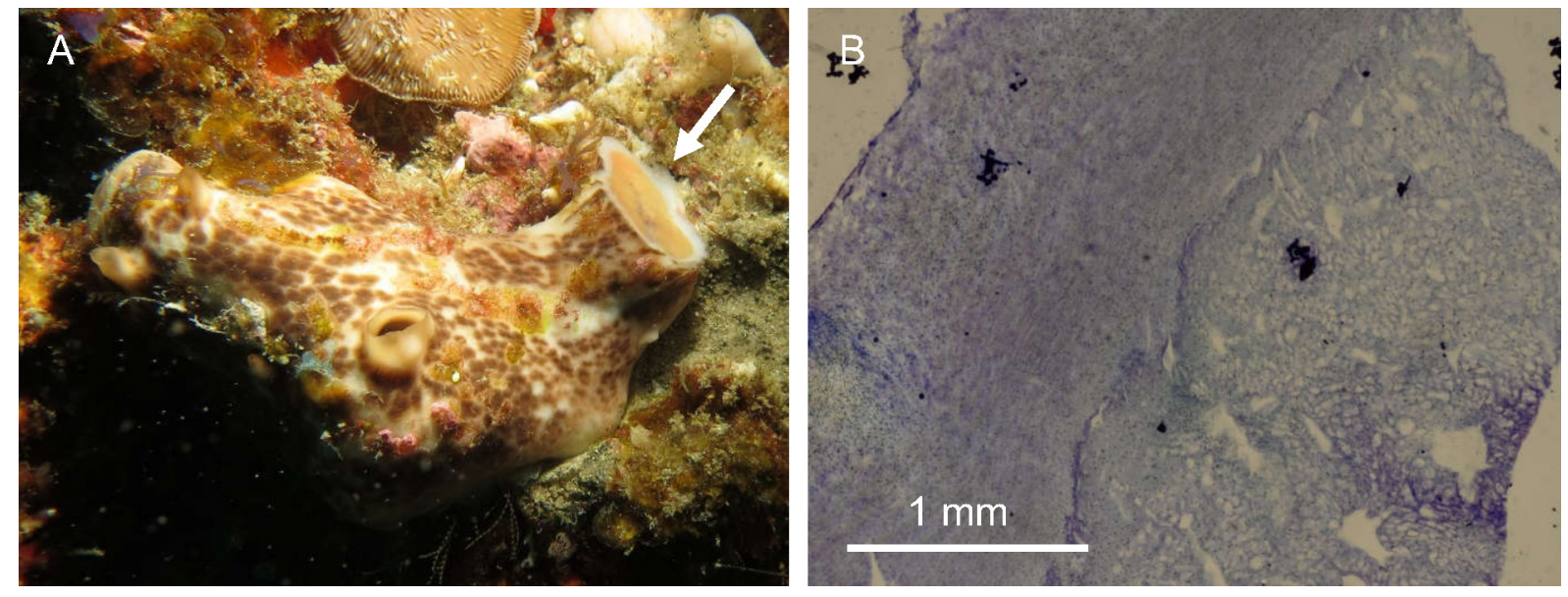

Fig. 2. Chondrosia corticata Thiele, 1900. A. Specimen (PO7) in situ. The arrow points a fresh cut showing the sponge's thick ectosome. B. Histological section showing the thick ectosome and the cavernous choanosome. 
This genus includes 10 accepted species and one (C. pendulus Gammil, 1997) under inquirendum (Van Soest et al. 2019). Among the species from the Indo-Pacific Area, C. chucalla de Laubenfels, 1936 differs from the studied material in the thinner cortex $(250 \mu \mathrm{m})$ and in the amount of foreign material described as "enormous". Chondrosia debilis Thiele, 1900 has been recorded in this ecoregion (Lévi 1958; Vacelet \& Vasseur 1965, 1971, 1976), but it differs in the characteristic wrinkles of the surface. Chondrosia ramsayi Lendenfeld, 1885 differs in its color, varying from bluish black to dark brown, and its rough surface. The inner part is dark brown. Chondrosia reticulata (Carter, 1885) is rich in foreign materials and doesn't show a clear cortex. Chondrosia rugosa Hentschel, 1909 has a surface covered by papillae and wrinkles and a slightly thicker $(0.7-1.5 \mathrm{~mm})$ cortex.

The described specimen fits with Chondrosia corticata in the general morphology, color, and mainly in the presence of a thick cortex, embedded with foreign spicules and debris, that is peculiar in this species (Thiele 1900).

This is the first record for the Western Indian Ocean.

Order Verongiida Bergquist, 1978

Family Pseudoceratinidae Carter, 1885

Genus Pseudoceratina Carter, 1885

Pseudoceratina purpurea (Carter, 1880)

Fig. 3

Aplysina purpurea Carter, 1880: 36.

\section{Material examined}

PONTA DO OURO • two fragments of about $5 \times 2 \times 2$ and $6 \times 3 \times 3 \mathrm{~cm} ; 26^{\circ} 49^{\prime} 17.512^{\prime \prime} \mathrm{S}, 32^{\circ} 53^{\prime} 42.514^{\prime \prime} \mathrm{E}$; Kev's; 23.4 m deep; 3 Feb. 2017; Cerrano leg.; PO4 - 1 spec.; Jenny’s Paradise; 26²66'50.336" S, 3254'12.329" E; 17.8 m deep; 12 Apr. 2017; Cerrano leg.; PO97.

\section{Description}

The live specimens are massively encrusting (Fig. 3A) or massively, irregularly spherical (Fig. 3B). They have an uneven surface with scattered, small, sharp conules and prominent oscula (Fig. 3B). The
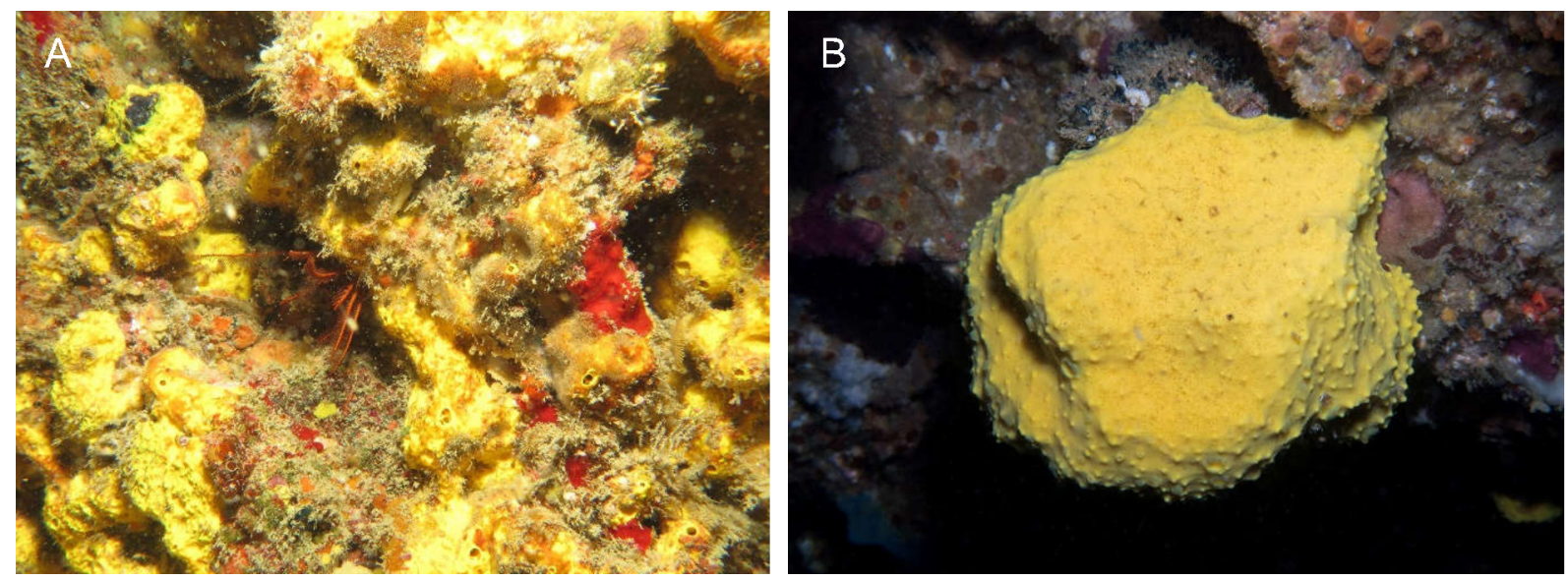

Fig. 3. Pseudoceratina purpurea (Carter, 1880). A. Encrusting specimen in situ (PO4). B. Massive specimen in situ (PO97). 
live sponge is light yellow (Fig. 3A-B); the alcohol-preserved specimens become dark purple, and have a smooth and irregular surface. The consistence is tough.

SKELETON. Spongin fibers scarcely developed, the choanosome is collagenous.

\section{Remarks}

The specimens belong to the genus Pseudoceratina Carter, 1885 due to the fibrous, dendritic skeleton and to the dense and collagenous matrix. There are four valid species in this genus, all with an IndoPacific distribution (Van Soest et al. 2019). Pseudoceratina arabica (Keller, 1889) contains abundant fibers and is characterized by high conules; $P$. durissima Carter, 1885 has been recorded in south-east Australia and shows a blue-black live color, with a smooth surface. Pseudoceratina verrucosa Bergquist, 1995 differs in its strongly verrucose surface and thicker fibers.

The specimens fit perfectly with the original description of Pseudoceratina purpurea (Carter, 1880) in the general morphology and in the scarcely developed fibers. More recent, complete description and illustrations are available in Bergquist (1965: 135, fig. 6, as Psammaplysilla purpurea).

The species is widely distributed in the Indo-Pacific Ocean and has been already recorded in Madagascar (Vacelet et al. 1976).

Order Dictyoceratida Minchin, 1900

Family Spongiidae Gray, 1867

Genus Hyattella Lendenfeld, 1888

Hyattella sulfurea Calcinai \& Belfiore sp. nov. urn:1sid:zoobank.org:act:35359CE5-EA33-4149-86E7-A221B964A78E

Fig. 4

\section{Diagnosis}

A species of Hyattella characterized by its light yellow color and fibers without inclusions.

\section{Etymology}

Named after its yellow color in life, from the Latin name 'sulfureus', meaning 'yellow'.

\section{Material examined}

\section{Holotype}

PONTA DO OURO - 3 small fragments, size of the largest about $3 \times 1.5 \times 07 \mathrm{~cm} ; 26^{\circ} 50^{\prime} 36.881^{\prime \prime} \mathrm{S}$, 3254'54.471" E; Atlantis; 47.7 m deep; 4 Mar. 2017; Cerrano leg.; MSNG 61417.

\section{Description}

The live sponge (Fig. 4A) is spherical, irregularly massive; on the surface, a net of fibers creates a clear web pattern connecting the prominent oscula among the thin cuticle. Where the sponge is not covered by foreign material and epibionts, the color appears light yellow (Fig. 4A). The color in the preserved state is dark brown (the pigments colored also the alcohol with a dark pinkish tinge). The sponge is firm and compressible; the body is lacunose.

SKELETON. It consists of a quite regular network of primary fibers, $25-55 \mu \mathrm{m}$ wide, the secondary fibers, 10-20 $\mu \mathrm{m}$ wide, form polygonal meshes of 200-250 $\mu \mathrm{m}$ in dimensions (Fig. 4B). Primary fibers less common with respect to secondary ones. All the fibers are free from inclusions. 

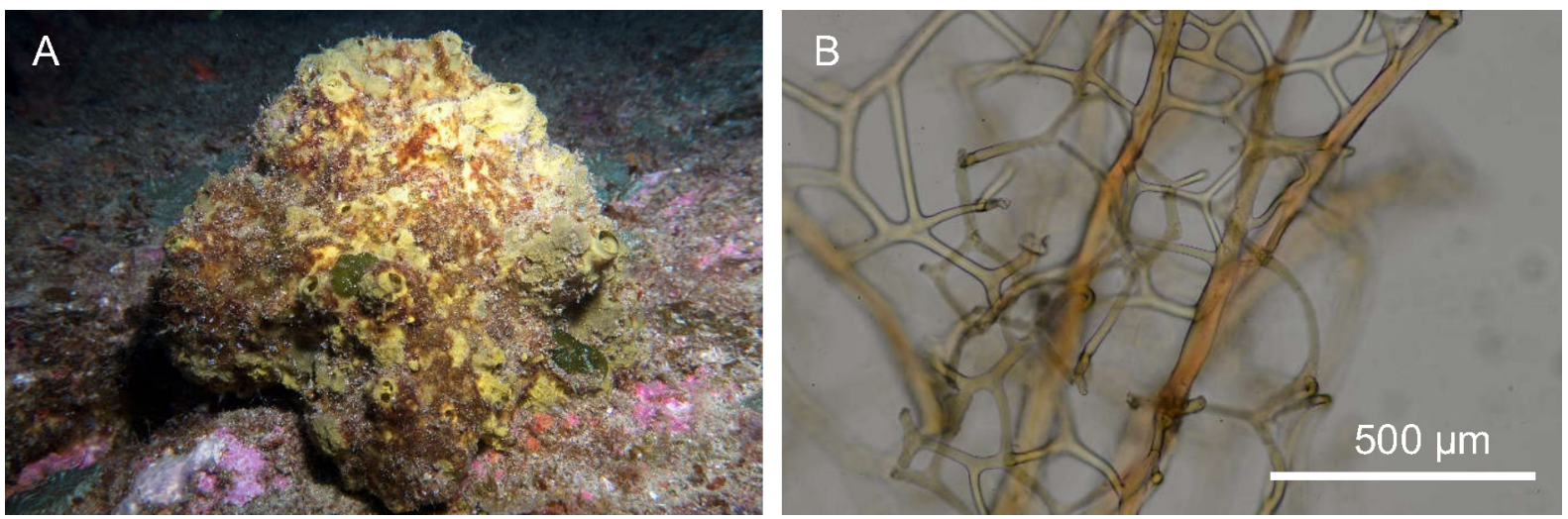

Fig. 4. Hyattella sulfurea Calcinai \& Belfiore sp. nov. A. Holotype MSNG 61417 in situ. B. Network of primary fibers.

\section{Remarks}

The species of the genus Hyattella have a lacunose body, an unarmoured surface and a skeleton composed of common, primary fibers linked by secondary fibers; primary fibres are cored and the secondary are free of inclusion (Cook \& Bergquist 2002). However, the species Hyattella cavernosa (Pallas, 1766), whose skeleton is free of foreign material (see Lendenfeld 1889: 298, as Hippospongia dura), such as $H$. sulfurea sp. nov., is included in this genus. On that note, we consider the species here described belonging to the genus Hyattella, on the basis of its lacunose body, unarmored surface, common primary fibers and the presence of a dermal reticulation. Other related genera, such as Spongia Linnaeus, 1759 and Hippospongia Schulze, 1879 include species devoid of a lacunose body, or devoid of common primary fibers or a dermal reticulation.

This genus includes 21 species, all with an Indo-Pacific distribution except for $H$. obscura Lendenfeld, 1889 and H. cavernosa (Pallas, 1766) from the Atlantic Ocean (Van Soest et al. 2019). All these species are characterized by thicker primary and secondary fibers. Only H. meander Lendenfeld, 1889 has thinner primary and secondary fibers of $47 \mu \mathrm{m}$ and $27-47 \mu \mathrm{m}$, respectively, but it is branched and its primary fibers are full of sand.

Hyattella pedunculata Calcinai \& Belfiore sp. nov. urn:1sid:zoobank.org:act:5D86D9AC-962D-48A7-BF1D-12879B09E573

Fig. 5

\section{Diagnosis}

A species of Hyattella characterized by a globular body, supported by a short stalk; small-sized fibers and free of inclusion.

\section{Etymology}

The species is named 'pedunculata' due to its characteristic stalk, in Latin 'pedunculus'.

\section{Material examined}

\section{Holotype}

PONTA DO OURO • fragment about $7 \times 3 \times 2.5 \mathrm{~cm} ; 26^{\circ} 46^{\prime} 38.829^{\prime \prime} \mathrm{S}, 32^{\circ} 54^{\prime} 17.381^{\prime \prime} \mathrm{E}$; Waynes; $40.6 \mathrm{~m}$ deep; 17 Feb. 2017; Cerrano leg.; MSNG 61418. 


\section{Paratype}

PONTA DO OURO $\bullet 2$ fragments, the biggest, preserved dry, is $3 \times 2 \times 1.5 \mathrm{~cm}$; Cloud break; 18 May 2015; Torsani leg; MSNG 61419.

\section{Description}

The sponge is pedunculate and the massive, globular body is supported by a short stalk (Fig. 5A-B). The color is reddish-pink, but in alcohol it turns creamy. The reddish color is still preserved in the dried
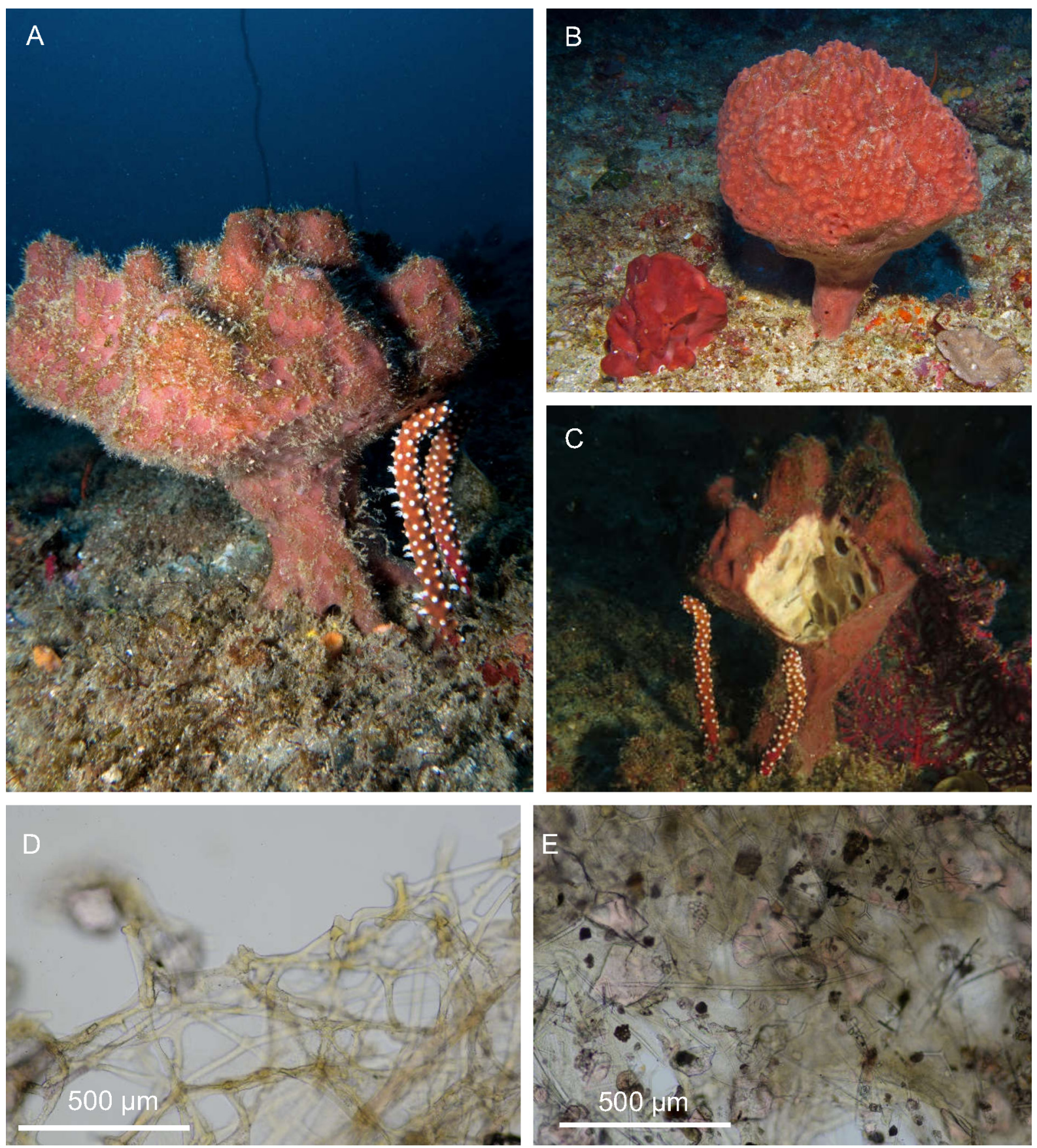

Fig. 5. Hyattella pedunculata Calcinai \& Belfiore sp. nov. A, C. Specimen in situ, paratype MSNG 61419; C shows the internal, lacunose body. B. Holotype MSNG 61418. D. Network of fibers. E. Superficial cuticle with foreign sand. 
state. The paratype (MSNG 61419) presents irregular short and thick digitations (Fig. 5A, C) while in the holotype (MSNG 61418) the surface is more even (Fig. 5B). At a microscopic observation, the surface is smooth and appears cribrous; the consistence is firm but compressible. The body is cavernous, completely perforated by large lacunae (Fig. 5C).

SKELETON. It consists of a network of long primary fibers, $10-25 \mu \mathrm{m}$, linked by very short secondary fibers, 7.5-20 $\mu \mathrm{m}$ in diameter, forming irregular meshes, around $250 \mu \mathrm{m}$ wide (Fig. 5D); fibers are free from inclusions. Presence of rounded foreign bodies $100-200 \mu \mathrm{m}$ in section on superficial cuticle (Fig. 5E).

\section{Remarks}

The specimens belong to the genus Hyattella Lendenfeld, 1888, showing a lacunose body, an unarmoured surface and a skeleton composed by common primary fibers linked by secondary fibers. This species is characterized by the small size of its primary and secondary fibers compared to the size of the fibers in the other species of the genus; moreover, the pedunculate shape is rare among species of the genus Hyattella; only Hyattella globosa Lendenfeld, 1889 partially fits the studied specimens in the general morphology (spherical sponge, attached by a small base) and in its cribrose surface. The principal differences are in the larger dimensions of the fibers (up to $100 \mu \mathrm{m}$ ) and in the presence of compound meshes creating 'perforated plates' in H. globosa.

Order Haplosclerida Topsent, 1928

Family Callyspongiidae Laubenfels, 1936

Genus Callyspongia Duchassing \& Michelotti, 1864

Callyspongia (Cladochalina) Schmidt, 1870

Callyspongia (Cladochalina) aerizusa Desqueyroux-Faundez, 1984

Fig. 6

Callyspongia (Cladochalina) aerizusa Desqueyroux-Faundez, 1984: 803, figs 18, 21, pl. 18, pl. 21 figs $157-161$.

\section{Material examined}

PONTA DO OURO $~ 1$ alcohol preserved fragment of about $4 \times 2 \times 1 \mathrm{~cm}$; Doodle; $26^{\circ} 49^{\prime} 50.408^{\prime \prime} \mathrm{S}$, 32 53'45.97" E; $18 \mathrm{~m}$ deep; 14 Nov. 2015; Cerrano leg.; PdO18a 2 small fragments, alcohol preserved, about $3 \times 1 \times 1 \mathrm{~cm} ; 26^{\circ} 50^{\prime} 36.881^{\prime \prime} \mathrm{S} 32^{\circ} 53^{\prime} 42.5^{\prime \prime}$ E; Kev's; $24.1 \mathrm{~m}$ deep; $11 \mathrm{Mar}$. 2017; Cerrano leg.; PO82 • 1 specimen preserved dry, $7 \times 1 \times 1 \mathrm{~cm} ; 26^{\circ} 46^{\prime} 55.65^{\prime \prime} \mathrm{S}, 32^{\circ} 54^{\prime} 13.413^{\prime \prime} \mathrm{E}$; Three Sisters; $24.2 \mathrm{~m}$ deep; 14 Mar. 2017; Cerrano leg.; PO86.

\section{Description}

Live sponge erect, cylindrical-tubular (Fig. 6A-B); the examined specimens are pink (Fig. 6B), pale violet (Fig. 6A) or creamy-white (Fig. 6C). The samples, preserved in alcohol, turn sand-colored, while the dryly preserved sample is creamy-white colored. The surface is strongly conulose (Fig. 6A-C). The consistence is very tough, elastic and compressible in samples preserved in alcohol, while the dried sample is very firm and uncompressible.

SkelEton. Ectosome (Fig. 6D) formed by reticulation of three sizes of fibers running tangentially: multispicular primary fibers, $40-110 \mu \mathrm{m}$ in section, forming triangular-polygonal meshes of 490-850 $\mu \mathrm{m}$ in size; pauci-multispicular secondary fibers $15-50 \mu \mathrm{m}$ and unispicular (at most 3 ) tertiary fibers, $5-(7.3,1.8)-10 \mu \mathrm{m}$, forming sub-triangular meshes. Choanosome (Fig. 6E) formed by the reticulation of thick ascending multispicular primary fibers, $60-110 \mu \mathrm{m}$ in section; the primary fibers are linked 
through pauci-multispicular secondary fibers, $20-70 \mu \mathrm{m}$, forming quite regular rectangular meshes of $240-360 \times 220-250 \mu \mathrm{m}$ in dimensions; presence also of the third size of unispicular fibers, $4-10 \mu \mathrm{m}$.

Spicules. Slender and slightly curved oxeas with acerate and rounded tips (Fig. 6F), 70-(87.5, 8.5)$95 \mu \mathrm{m} \times 2-(4.25,1.2)-5 \mu \mathrm{m}$.
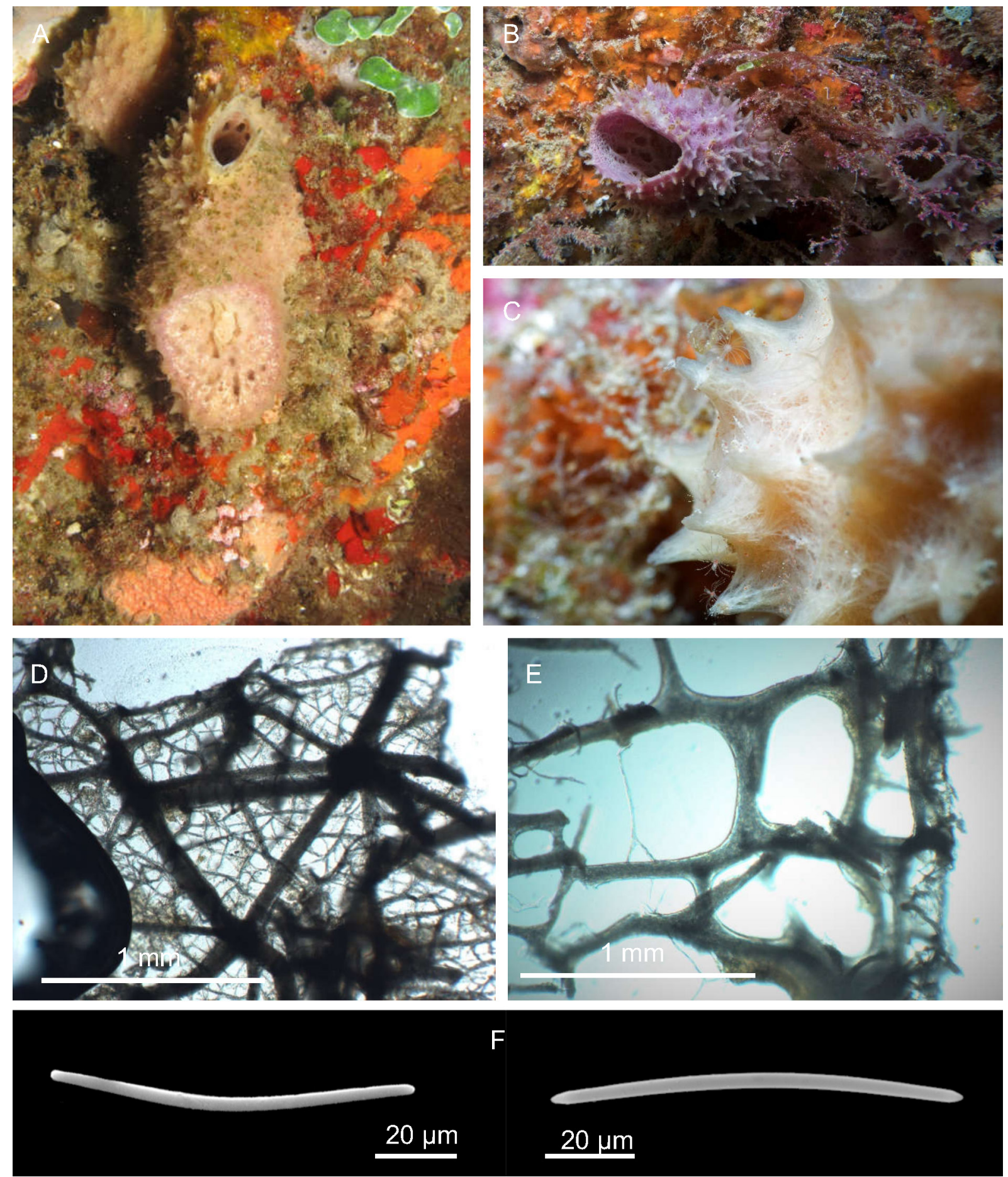

Fig. 6. Callyspongia (Cladochalina) aerizusa Desqueyroux-Faundez, 1984. A-C. Specimens in situ, respectively PdO18a, PO82 and PO86. D. Ectosomal skeleton. E. Choanosomal skeleton. F. Oxeas. 


\section{Remarks}

These specimens belong to the subgenus Callyspongia (Cladochalina) Schmidt, 1870 based on the growth form, spiny surface, three sizes of irregular mesh in the ectosome and three sizes of irregular mesh in choanosomal skeleton (Desqueyroux-Faundez \& Valentine 2002a).

Hitherto, 27 species are assigned to this subgenus, 19 of which have a distribution in the Indo-Pacific Ocean. The original descriptions of C. (Cladochalina) manus Lendenfeld, 1887, C. (Cladochalina) spinifera (Carter, 1887), C. (Cladochalina) rautenfeldi (Topsent, 1928), C. (Cladochalina) asparagus (Lamarck, 1814), C. (Cladochalina) aspericornis (Lamarck, 1814) and C. (Cladochalina) plancella (Lamarck, 1814) are insufficient and they remain as unique records of the respective species. Callyspongia (Cladochalina) affinis (Hentschel, 1912), compared to our specimens, has spicules different in shape and size (tornotes of $100 \mu \mathrm{m}$ ). Callyspongia (Cladochalina) glomerata (Whitelegge, 1897), C. (Cladochalina) foliacea (Esper, 1797) and C. (Cladochalina) pergamentacea (Ridley, 1881) have a different shape (respectively cake-shaped with tubes, sub-erect and irregular shape and massiveglobular shape).

Other species differ in the characteristics of the skeleton: C. (Cladochalina) diffusa (Ridley, 1884), C. (Cladochalina) oriamensis Pulitzer-Finali, 1982, C. (Cladochalina) spinosissima (Dendy, 1887), C. (Cladochalina) spinilamella (Dendy, 1889) and C. (Cladochalina) thurstoni (Burton, 1930) have different shapes of the meshes, while C. (Cladochalina) subarmigera (Ridley, 1884) has thicker choanosomal fibers and unispicular ectosomal fibers; C. (Cladochalina) saramensis (Wilson, 1925) has smaller choanosomal fibers of 40-50 $\mu \mathrm{m}$. Callyspongia (Cladochalina) fibrosa (Ridley \& Dendy, 1886) differs in the spicule size $(100 \times 3.2 \mu \mathrm{m})$ and in the general morphology (branched).

The morphology, the skeleton and the spicule size of the specimens entirely fit the original description of Callyspongia (Cladochalina) aerizusa Desqueyroux-Faundez, 1984.

The hydroid Zyzzyzus warreni Calder, 1988 (Class Hydrozoa, Phylum Cnidaria) grew on two specimens.

This is the first record of $C$. (Cladochalina) aerizusa in the Indian Ocean. Hitherto, others were in the Great Barrier Reef and in New Caledonia, where the holotype was recorded.

Callyspongia (Euplacella) Lendenfeld, 1887

Callyspongia (Euplacella) abnormis Pulitzer-Finali, 1993

Fig. 7

Callyspongia abnormis Pulitzer-Finali, 1993: 340, fig. 78.

\section{Material examined}

PONTA DO OURO -5 fragments preserved dry, the larger is about $10 \times 3 \mathrm{~cm}$ and $4 \mathrm{~mm}$ thick;

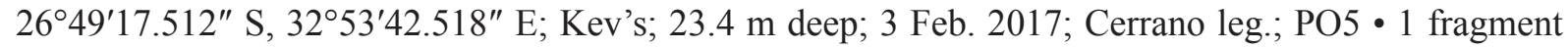

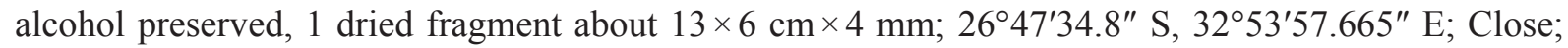
$18.6 \mathrm{~m}$ deep; 9 Feb. 2017; Cerrano leg.; PO30 • Slide preparations of the holotype, labelled MBA 167, belonging to the author's personal collection.

\section{Description}

Live sponges erect, foliaceous, lamellar, about 4-5 mm thick, and with scattered, digitate processes (Fig. 7A-B). On one side of the sponge, roundish vents, about 300-400 $\mu \mathrm{m}$ in diameter, are grouped (Fig. 7B), while on the opposite side, numerous pores are scattered and not visible to the naked eye. The 

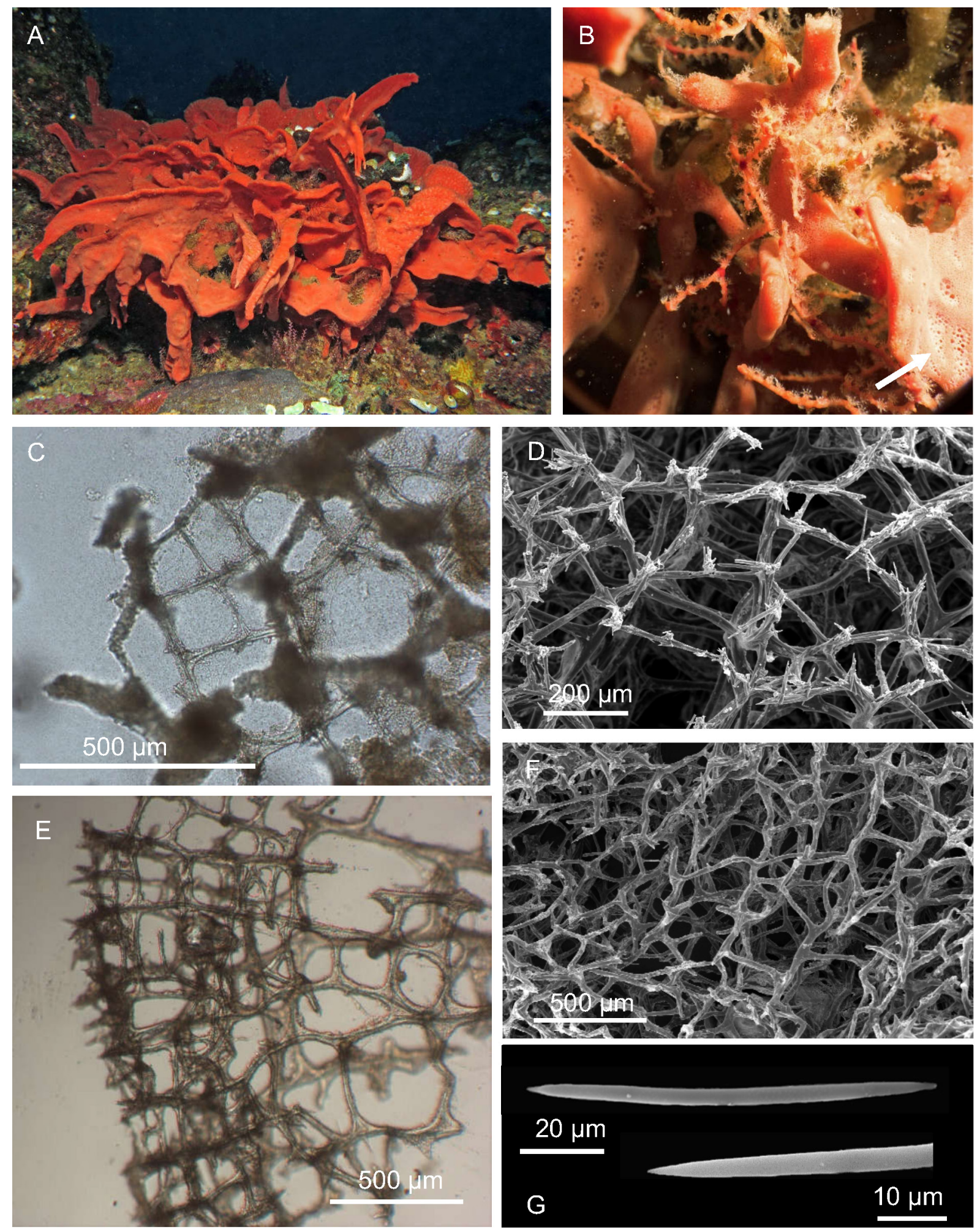

Fig. 7. Callyspongia (Euplacella) abnormis Pulitzer-Finali, 1993. A. The specimen PO30 in situ. B. Magnification of the specimen PO5, with groups of roundish vents in evidence (arrow). C. Ectosomal skeleton. D. SEM picture of the ectosomal skeleton. E. Choanosomal skeleton. F. SEM picture of the choanosomal skeleton. G. Oxea and magnification of the tip. 
color in life is brick red; ochre in preserved specimens. Surface optically smooth, but microhispid at microscope magnification. The consistence is soft and compressible, rough at touch.

Skeleton. Ectosome (Fig. 7C-D) formed by a reticulation of paucispicular (2-5 oxeas) fibers, $18-35 \mu \mathrm{m}$ in section, with no marked difference between primary and secondary fibers; the meshes are irregular and 150-350 $\mu \mathrm{m}$ wide, and are echinated by free spicules. Choanosome (Fig. 7E-F) formed by reticulation of thicker, paucispicular (4-8 oxeas) fibers, $30-45 \mu \mathrm{m}$, that form irregular, rounded or polygonal meshes, 230-360 $\mu \mathrm{m}$ wide.

SPICULES. Slender and slightly curved oxeas with acerate tips, $90-(102.5,11.9)-115 \mu \mathrm{m} \times 2-(5,1.4)-6 \mu \mathrm{m}$ (Fig. 7G).

\section{Remarks}

These samples fit with C. abnormis Pulitzer-Finali, 1993 from Mombasa, Kenya, in external morphology, skeleton structure, and spicule shape and size. The examination of the slides of the holotype confirms the identification. This new finding allowed us to assign the species to the subgenus Euplacella, considering that the ectosomal skeleton is made by one size of small rounded mesh, echinated by spicules. This is the first record of the species since its original description.

Callyspongia (Callyspongia) Duchassaing \& Michelotti, 1864

Callyspongia (Callyspongia) pulitzeri Van Soest \& Hooper, 2020 Fig. 8

Callyspongia subtilis Pulitzer-Finali, 1993: 338, fig. 76.

\section{Material examined}

PONTA DO OURO • 1 small fragment of a branch, about $3 \times 1 \times 1 \mathrm{~cm} ; 26^{\circ} 46^{\prime} 39.864^{\prime \prime} \mathrm{S}, 32^{\circ} 55^{\prime} 25.355^{\prime \prime} \mathrm{E}$; Cloud break; $36 \mathrm{~m}$ deep; 22 May 2015; Torsani leg.; IMG0827 - Slide preparation of the holotype, labelled KEN.59, belonging to the author's personal collection.

\section{Description}

Live sponge branching in shape, with prominent oscula organized in a row in the upper side (Fig. 8A). Color is light violet with visible whitish lines (Fig. 8A). The dried specimen is microhispid and spiny in the upper surface, close to the oscula, smoother in the basal part. The consistence is tough and incompressible.

Skeleton. Ectosome formed by a reticulation of unispicular primary fibers, $25-45 \mu \mathrm{m}$ in section, and secondary unispicular fibers, $10-15 \mu \mathrm{m}$ (Fig. 8B); the meshes are quadrangular and quite regular (Fig. 8B-C), 230-270 $\times 250-350 \mu \mathrm{m}$. Choanosome formed by a regular reticulation of multispicular fibers, $45-65 \mu \mathrm{m}$ in section, linked by secondary spongin fibers (Fig. 8D-E). These are cored by single oxeas (monospicular) and are $25-35 \mu \mathrm{m}$ in section (Fig. 8D). The rounded meshes formed are 180$275 \mu \mathrm{m}$ wide.

Sicules. Slightly curved oxeas with acerate tips (Fig. 8F), $77.5-(87,6.3)-97.5 \mu \mathrm{m} \times 1.25-(3.76,1.1)-5 \mu \mathrm{m}$.

\section{Remarks}

The morphology, skeleton, and spicule size, as well as the shape of the examined specimen fit those of the original description from North Kenya Banks. Moreover, the prominent oscula organized in a row on the upper side and the multispicular primary fibers of the choanosome are peculiar characteristics. The examination of the holotype (Callyspongia subtilis Pulitzer-Finali, 1993) confirms the identification. 
Callyspongia subtilis Pulitzer-Finali, 1993 was a junior homonymy recently removed by Van Soest \& Hooper (2020) who renamed the species in honor of Gustavo Pulitzer-Finali.

This is the first record of the species since its original description from Kenya.
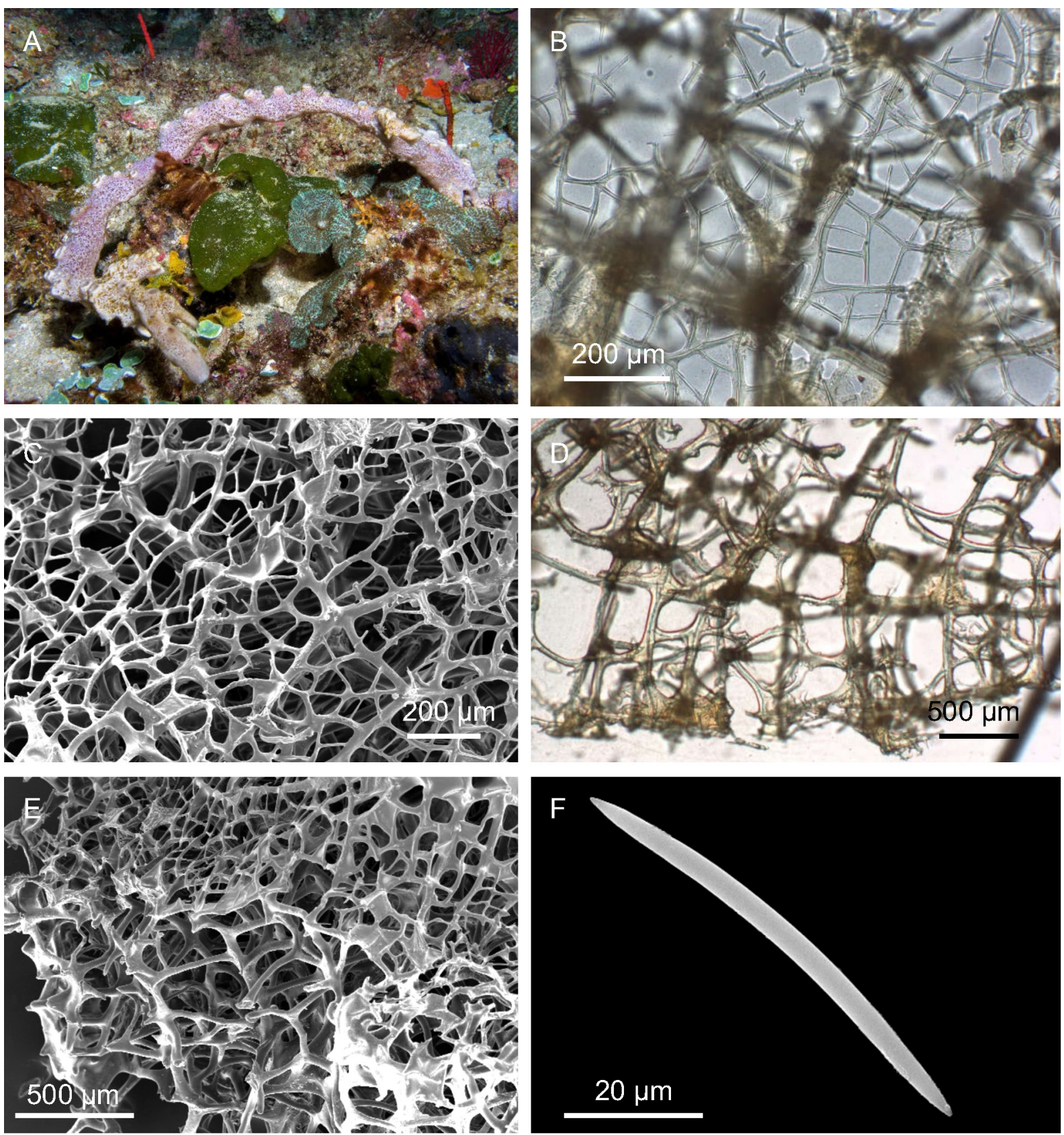

Fig. 8. Callyspongia (Callyspongia) pulitzeri Van Soest \& Hooper, 2020. A. Specimen IMG0827 in situ. B. Ectosomal skeleton. C. SEM picture of the ectosomal skeleton. D. Ectosomal skeleton. E. SEM picture of the choanosomal skeleton and small portion of the ectosome on the top left of the figure. F. Oxea. 
Family Niphatidae Van Soest, 1980

Genus Amphimedon Duchassaing \& Michelotti, 1864

Amphimedon brevispiculifera (Dendy, 1905)

Fig. 9

Pachychalina brevispiculifera Dendy, 1905: 149, pl 10 fig. 7.

\section{Material examined}

PONTA DO OURO • 2 branches, about $4 \mathrm{~cm}$ long, alcohol preserved; $26^{\circ} 49^{\prime} 55.65^{\prime \prime} \mathrm{S}, 32^{\circ} 53^{\prime} 13.417^{\prime \prime} \mathrm{E}$; Three Sisters; 23.9 m deep; 21 Feb. 2017; Cerrano leg.; PO65.

\section{Description}

The live sponge is arborescent, with flattened branches often anastomosing (Fig. 9A); oscules are numerous and concentrated on the upper margin of the branches (Fig. 9A). Light purple in vivo, the specimen conserved in alcohol is pale yellow; the surface is smooth, the consistence is firm and elastic. The preserved sample consists of two small fragments; the biggest being a small branch about $4 \mathrm{~cm}$ long and $1.5 \mathrm{~cm}$ thick.
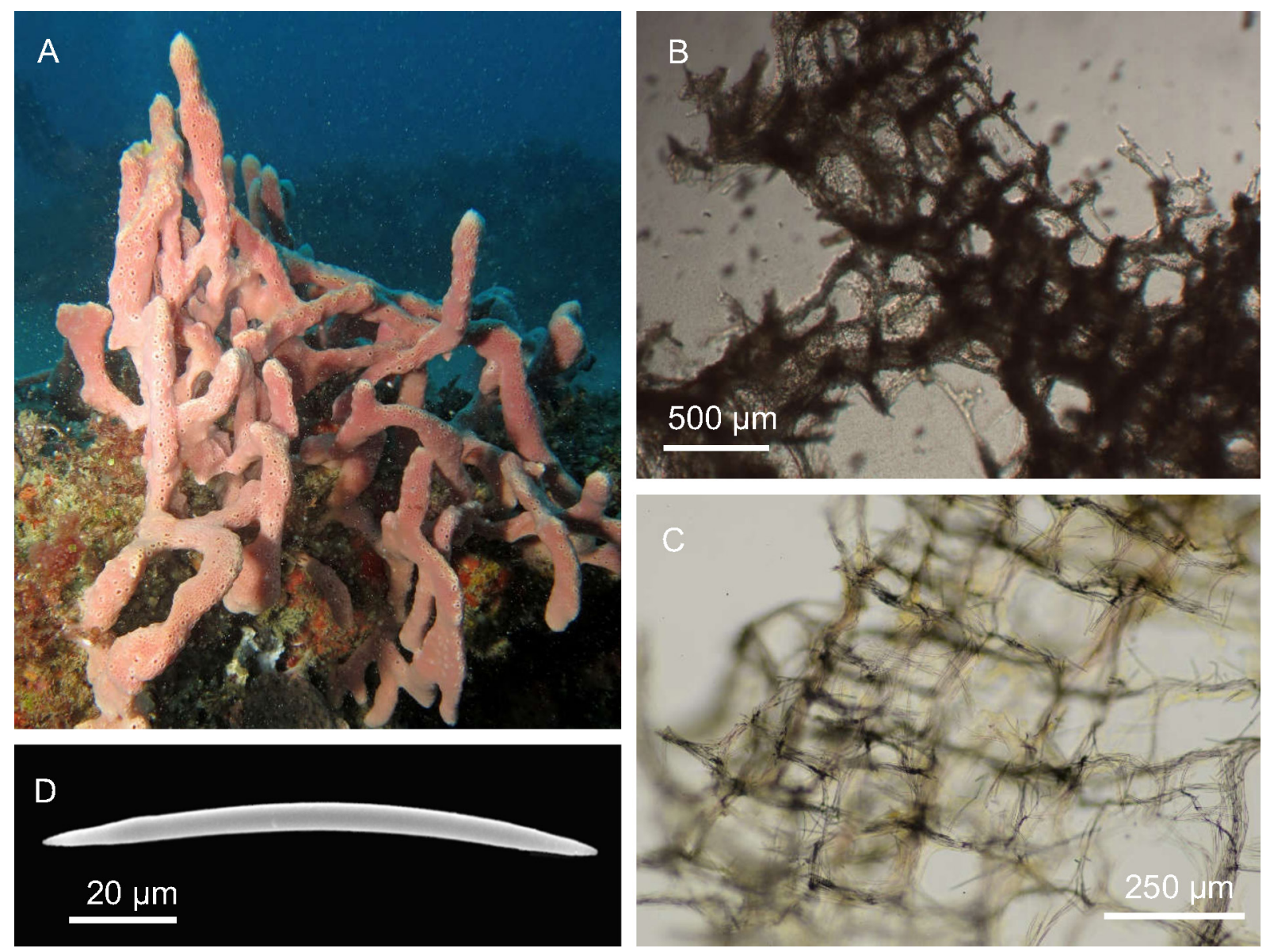

Fig. 9. Amphimedon brevispiculifera (Dendy, 1905). A. Specimen PO65 in situ. B. Ectosomal skeleton. C. Choanosomal skeleton. D. Oxea. 
Skeleton. Ectosome (Fig. 9B) formed by multispicular fibers, rich in spongin, with the diameter ranging between 20 and $75 \mu \mathrm{m}$, creating irregular, rounded meshes of 100-200 $\mu \mathrm{m}$. Echinating spicules, at the end of the choanosomal primary fibers, protrude at the nodes. Choanosome (Fig. 9C) consists of multispicular primary fibers as well as multispicular secondary fibers, of about the same thickness (20-90 $\mu \mathrm{m}$ in diameter), forming rectangular meshes (average of $100 \times 175 \mu \mathrm{m}$ ).

Spicules. Short, stout and sharp oxeas, 80-(88.5, 4.4)-95×2.5-(2.75, 1.3)-3 $\mu \mathrm{m}$ (Fig. 9D).

\section{Remarks}

Out of 57 species of the genus Amphimedon, 30 are recorded in the Indo-Pacific Ocean (Van Soest et al. 2019). The examined specimen fits with A. brevispiculifera described from the Gulf of Manaar. They share the same general morphology, disposition of the oscules and the short dimension of the spicules $(100 \times 5.5 \mu \mathrm{m})$; the species name "brevispiculifera" means 'with short spicules'. All the other species of Amphimedon in the Indo-Pacific Ocean are characterized by longer oxeas.

The present specimen is apparently morphologically similar to the sponge recently recorded by Samaai et al. (2019) in South Africa and named Callyspongia (Cladochalina) diffusa sensu Samaai et al. (2019).

This species was previously known only from South India and Sri Lanka (Laccadive Sea); thus, it is the first record since its original description and a new record for the studied area.

Amphimedon palmata Calcinai \& Belfiore sp. nov. urn:1sid:zoobank.org:act:3A60B0A0-7705-4C64-96FE-83FF25D1045A

Fig. 10

\section{Diagnosis}

This species of Amphimedon is characterized by flattened and rounded branches, and oscules located on the branches' rims.

\section{Etymology}

Named after the sponge growth form, consisting of flat and rounded branches.

\section{Material examined}

\section{Holotype}

PONTA DO OURO • a branched portion, alcohol preserved, $5 \mathrm{~cm}$ high; $26^{\circ} 49^{\prime} 50.408^{\prime \prime} \mathrm{S}, 32^{\circ} 53^{\prime} 45.974^{\prime \prime} \mathrm{E}$; Doodle; 18 m deep; 14 Nov. 2015; Cerrano leg.; MSNG 61504.

\section{Description}

Live sponge arborescent-palmate (Fig. 10A), with oscula scattered on the upper margin of the flattened branches (Fig. 10A). The color is pinkish in life; ochre for the fragment preserved in alcohol. The surface is uneven, but optically smooth; the consistence is soft and compressible. The examined sample is a short palmate fragment $0.5-1 \mathrm{~cm}$ in thickness.

Skeleton. Ectosome (Fig. 10B) with multispicular primary fibers (40-60 $\mu \mathrm{m}$ in diameter) that form rounded and irregular meshes, $180-250 \mu \mathrm{m}$ wide, with paucispicular secondary fibers (15 $\mu \mathrm{m}$ in average diameter). In the best-preserved parts, the sponge is covered by a thin dermal membrane with scattered tangential oxeas (Fig. 10C). Choanosomal primary fibres protrude and are pierced by scattered spicules; the ascendants, multispicular primary fibers (35-50 $\mu \mathrm{m}$ in diameter), are linked to plurispicular secondary fibers $(20-50 \mu \mathrm{m}$ in diameter). The meshes are irregular or polygonal $(100-300 \mu \mathrm{m})$ (Fig. 10D). 
Spicules. Curved oxeas (Fig. 10E), 90-(103.5, 6.5)-112 $\mu \mathrm{m}$ in length and 2.75-(5.3, 0.9)-6.25 $\mu \mathrm{m}$ wide.

\section{Remarks}

This species belongs to the genus Amphimedon that is characterized by an optically smooth surface, and a regular, tangential, ectosomal network with rounded meshes of a single size. Ends of choanosomal, longitudinal, primary fibers are barely protruding. Spongin is abundant (Desqueyroux-Faúndez \& Valentine 2002b).

Out of 57 species of the genus Amphimedon, 30 are recorded in the Indo-Pacific Ocean, 13 of which are from the West Indian Ocean (Van Soest et al. 2019).
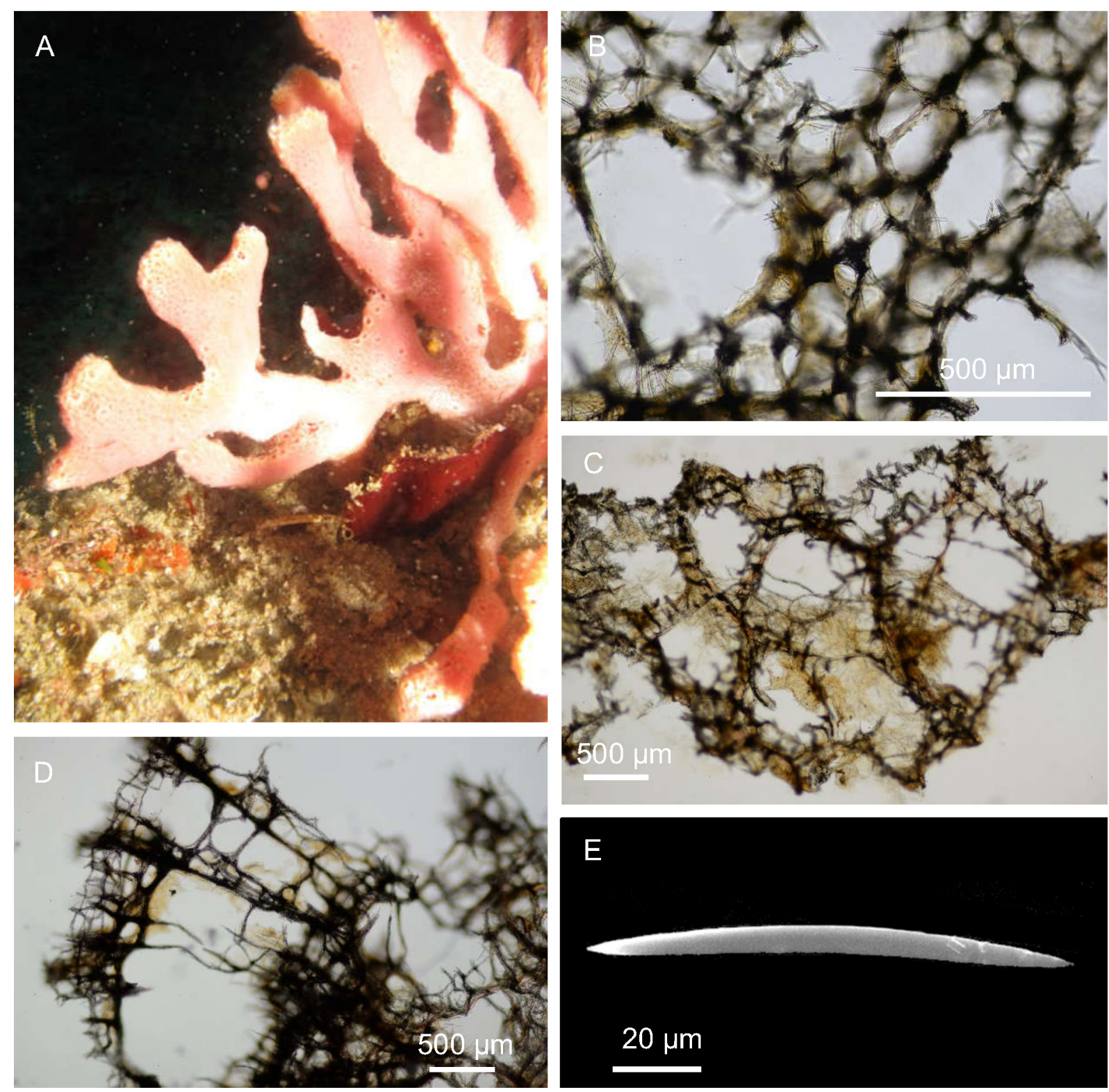

Fig. 10. Amphimedon palmata Calcinai \& Belfiore sp. nov. A. The holotype MSNG 61504 in situ. B. Ectosomal skeleton. C. Ectosomal skeleton covered by a thin dermal membrane with scattered tangential oxeas. D. Choanosomal skeleton. E. Oxea. 
The examined material is close to A. ochracea (Keller, 1889) in the fiber, mesh and spicule dimensions; Keller (1889), in fact, reported the main fibers with a thickness of $50 \mu \mathrm{m}$, and secondary fibers of 10-15 $\mu \mathrm{m}$. The mesh sizes are between 0.1 and $0.15 \mathrm{~mm}$. Oxeas are straight and pointed, $100 \mu \mathrm{m}$ long but thinner $(1.5 \mu \mathrm{m}$ in diameter). The main difference is in the shape, color and general morphology of the sponge. Keller's species is ochraceous and has rounded branches, while the new species is pinkish and has flattened branches; in A. ochracea the large oscules are star-shaped and located along the branches, not on the rims. Amphimedon brevispiculifera (Dendy, 1905), as described above, is purple and has a different skeleton structure. The other species of the area, A. chloros Ilan, Gugel \& Van Soest, 2004, A. dinae Helmy \& Van Soest, 2005, A. hamadai Helmy \& Van Soest, 2005, A. hispidula (Ridley, 1884), A. jalae Helmy \& Van Soest, 2005, A. navalis Pulitzer-Finali, 1993, A. rubida Pulitzer-Finali, 1993, A. rubiginosa Pulitzer-Finali, 1993 and A. spinosa Pulitzer-Finali, 1993, show a morphology from encrusting to cylindrical, never arborescent or palmate as the specimen here described. Amphimedon delicatula (Dendy, 1889), recorded from Sri Lanka, has a similar shape ("bushily lamellar"), but presents very stout choanosomal primary fibers, $126 \mu \mathrm{m}$ in diameter. Amphimedon subcilindrica (Dendy, 1905) is described as a cylindrical, repent-ramose sponge but with bigger oxeas $(140 \times 8 \mu \mathrm{m})$ and different choanosomal skeleton (stout primary fibers, up to $66 \mu \mathrm{m}$, and sub-rectangular meshes). All the other species are different either in spicule size, color or growth form.

Based on the peculiar morphological features of A. palmata sp. nov. and on the morphological differences with all the other species, A. palmata sp. nov. is considered a new species of the genus Amphimedon.

Family Phloeodictyidae Carter, 1882

Genus Oceanapia Norman, 1869

Oceanapia ramsayi (Lendenfeld, 1888)

Fig. 11

Rhizochalina ramsayi Lendenfeld, 1888: 188, pl. 3.

\section{Material examined}

PONTA DO OURO • 1 dried fragment of about $6 \times 1.5 \times 2 \mathrm{~cm} ; 26^{\circ} 49^{\prime} 17.512^{\prime \prime} \mathrm{S}, 32^{\circ} 53^{\prime} 42.5^{\prime \prime}$ E; Kev's; $17 \mathrm{~m}$ deep; 20 Nov. 2015; Cerrano leg.; PdO27 1 small fragment of about $3 \times 1 \times 1 \mathrm{~cm} ; 26^{\circ} 49^{\prime} 17.512^{\prime \prime} \mathrm{S}$, 3253'42.503" E; Kev's; 17 m deep; 20 Nov. 2015; Cerrano leg.; PdO28.

\section{Description}

Live sponge globular-massive, with oscular tubes arising from the upper surface (Fig. 11A-C). The two specimens had distinct colors in life: bright red on the exterior and yellow inside (Fig. 11A-B), and dark brown on the exterior and light brown inside (Fig. 11C). Both dried samples are dark brown, firm and with a smooth surface.

SKeleton. Ectosome (Fig. 11D) constituted of a reticulation of fibers, 30-100 $\mu \mathrm{m}$ in section, forming oval meshes of 350-400 $\mu \mathrm{m}$ of diameters and a secondary sub-isodictyal network of single oxeas. Choanosome formed by thick fibers of spicules, $30-50 \mu \mathrm{m}$ in section, forming irregularly rounded meshes, $180-380 \mu \mathrm{m}$.

Spicules. Slightly curved oxeas (Fig. 11E), 130-(156.7, 11.7)-170×2.5-(6.2, 1.7)-10 $\mu \mathrm{m}$, often with slightly mucronate tips. 


\section{Remarks}

The samples belong to the genus Oceanapia Norman, 1869, considering the numerous fistulae on the surface and the general skeleton structure. The genus includes 95 species, 75 of them from the IndoPacific Ocean (Santos Neto et al. 2018). The skeleton, spicule size and general morphology fit the original description of Oceanapia ramsayi Lendenfeld, 1888 from Australia. The holotype was described
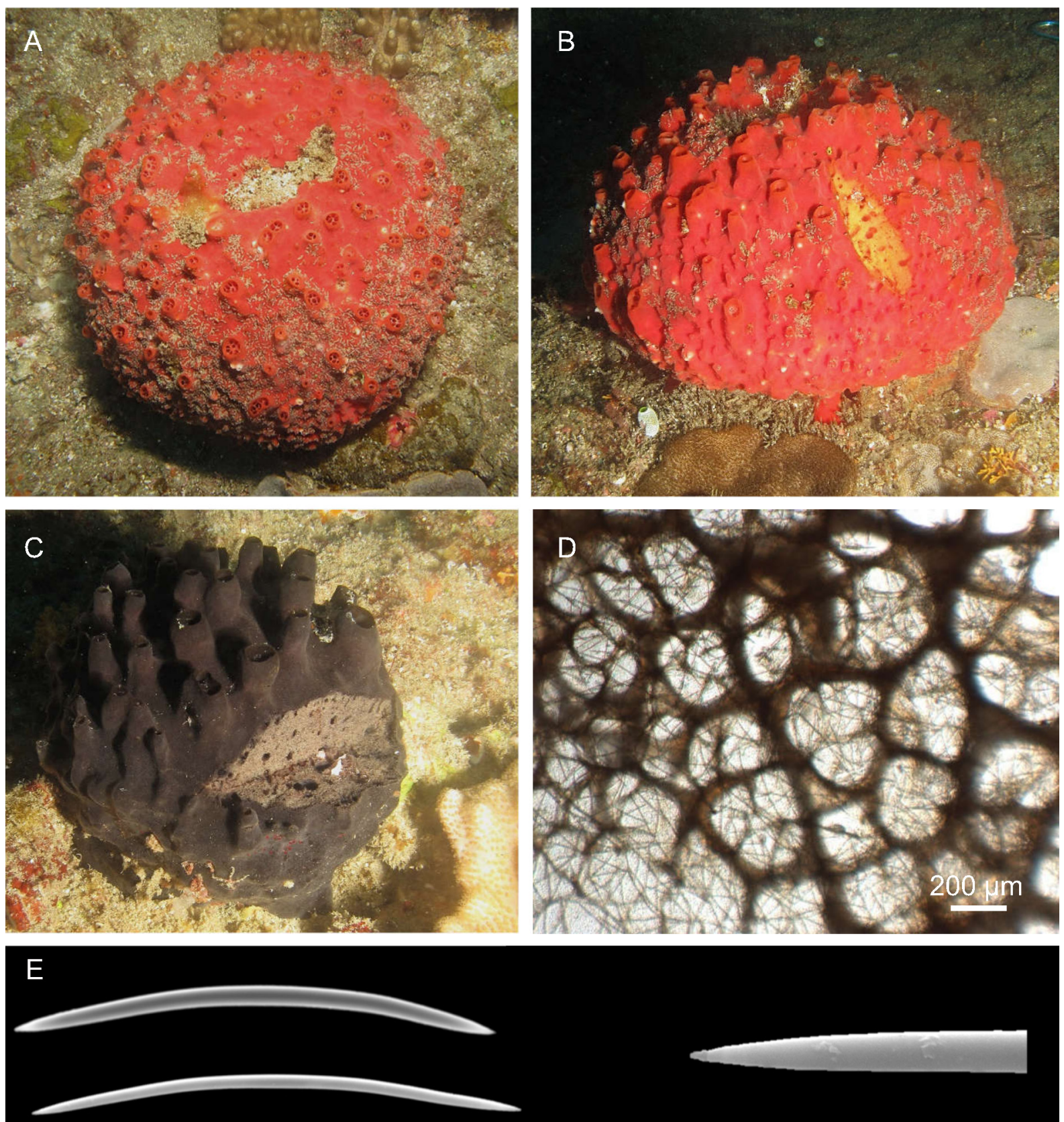

$50 \mu \mathrm{m}$

$10 \mu \mathrm{m}$

Fig. 11. Oceanapia ramsayi Lendenfeld, 1888. A-B. Red specimen in situ (PdO27); in B a fresh cut highlights the yellow choanosome. C. Brown specimen (PdO28). D. Choanosomal skeleton. E. Oxeas and magnification of a tip. 
as yellow, while other, subsequent records of this species report a red color, such as in Itampolo, Madagascar (Bensemhoun et al. 2008) and brown in Port Jackson, Australia (Hallman 1914). Moreover, Hallman pointed out that his specimen, different from the holotype, was devoid of stout, central tubes, although it occurs with the examined material from Mozambique. The species is also known from the east coast of South Africa (Schleyer et al. 2006).

Order Axinellida Lévi, 1953

Family Heteroxyidae Dendy, 1905

Genus Myrmekioderma Ehlers, 1870

\section{Myrmekioderma granulatum (Esper, 1829)}

Fig. 12

Alcyonium granulatum Esper, 1829: 71, pl. 24.

\section{Material examined}

PONTA DO OURO • 1 fragment $3 \times 2 \times 1$ cm; 26²49'50.408" S, 32 53'45.97" E; Doodle; 17.6 m deep; 20 Apr. 2017; Cerrano leg.; PO98.

\section{Description}

Live sponge massive, bulbous, partially burrowing (Fig. 12A) and with the surface covered by large, circular, low, rounded plates, similar to flat tubercles. Color bright orange, while the tubercles are darkred, brownish colored (Fig. 12A); the sample preserved in alcohol is beige. The sponge is fleshy and compressible. The surface appears smooth, but is micro-hispid at microscope magnification.

Skeleton. Ectosome composed of brushes of densely packed spicules (Fig. 12B). Choanosome constituted by a lax skeleton of ascending fibers of oxeas (Fig. 12B).
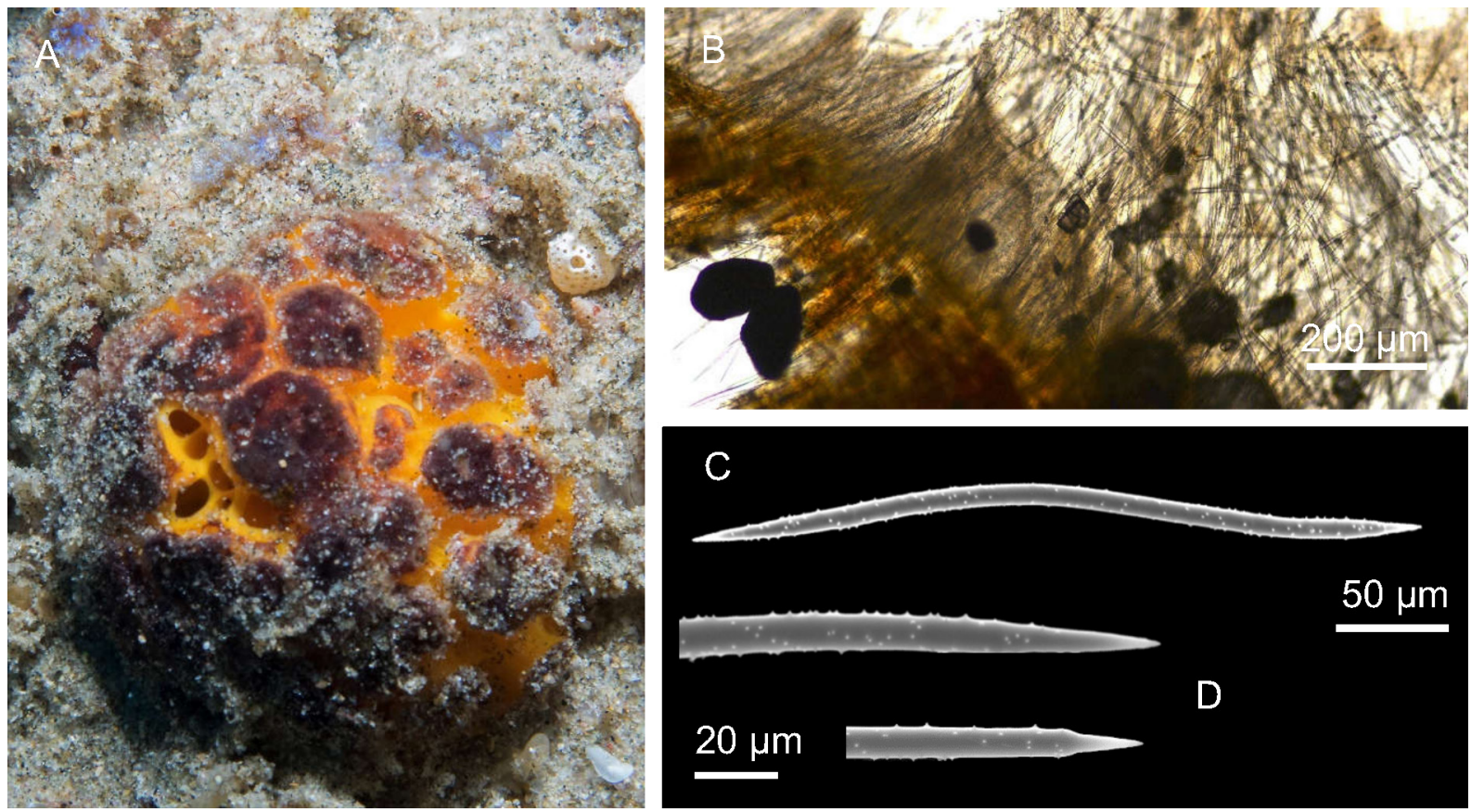

Fig. 12. Myrmekioderma granulatum (Esper, 1829). A. Specimen PO98 in situ. B. Ectosomal skeleton. C. Microspined and flexuous oxea. D. Magnifications of the tips. 
SPiCulEs. Oxeas microspined, slightly curved or flexuous (Fig. 12C), 260-(415, 176.6)-840 $\mu \mathrm{m} \times 7.5-$ $(10,2)-12.5 \mu \mathrm{m}$, tips acerate or stepped (Fig. 12D); less common, smooth oxeas with same characteristics; very thin raphids, in thricodragmas, on the surface $22.5-(29.25)-50 \mu \mathrm{m}$.

\section{Remarks}

The specimen belongs to the genus Myrmekioderma Elhers, 1870 characterized by a halichondroid organization of the choanosomal skeleton, a detachable ectosomal skeleton of acanthoxeas and by the presence of trichodragmata on the surface (Hooper 2002).

To date, there are 11 species belonging to this genus, six of which have records only in the Atlantic Ocean (Van Soest et al. 2019). Among the others, Myrmekioderma niveum (Row, 1911) presents a yellowish-white color and has just one category of smooth oxeas. Myrmekioderma dendyi (Burton, 1959) was recorded from Madagascar (Van Soest et al. 2019), but is characterized by an even surface with some digitate processes. Myrmekioderma pacificum Pulitzer-Finali, 1996 from the Bismark Sea has smooth and thicker oxeas $(7-45 \mu \mathrm{m})$ with, sometimes, strongylote modifications (never found in this specimen) and longer trichodragmata $(100-130 \mu \mathrm{m})$. Myrmekioderma tubercolatum (Keller, 1891), found in the Red Sea, has a different morphology and the spicule composition is different, with the absence of trichodragmata and the presence of strongylote modifications.

The very peculiar external morphology, with the rounded plates and the oxea shape, fit the descriptions of Myrmekioderma granulatum (Esper, 1829). This species has a wide distribution in the Indian and Pacific Ocean (Van Soest et al. 2019), with a corresponding high degree of variability, even concerning the presence or the absence of some spicule category (Bergquist 1965).

Order Tetractinellida Marshall, 1876

Family Theonellidae Lendenfelds, 1903

Genus Theonella Gray, 1868

Theonella conica (Kieschnick, 1896)

Fig. 13, Table 1

Discodermia conica Kieschnick, 1896: 530.

\section{Material examined}

PONTA DO OURO $~ 2$ fragments, the larger is about $8 \times 3 \times 2 \mathrm{~cm} ; 26^{\circ} 49^{\prime} 17.512^{\prime \prime} \mathrm{S}, 32^{\circ} 53^{\prime} 42.507^{\prime \prime} \mathrm{E}$; Kev's; $23.4 \mathrm{~m}$ deep; 3 Feb. 2017; Cerrano leg.; PO2 - 1 fragment, $4 \times 2 \times 1 \mathrm{~cm} ; 26^{\circ} 47^{\prime} 34.8^{\prime \prime} \mathrm{S}$, 32॰53'57.662" E; Close; 18.6 m deep; 9 Feb. 2017; Cerrano leg.; PO29.

\section{Description}

The live sponge is irregularly massive, lobate, with oscules either flush with the surface or opening upon mounds (Fig. 13A-C). The color of the surface is brown while the body is blueish. The samples preserved in alcohol are ochre with an uneven surface, in some parts microhispid. The consistence is firm and slightly compressible.

SKELETon. Ectosome consisting of phyllotriaenes and with a crust of numerous rhabds (Fig. 13D-E). Choanosome formed by tetraclone desmas and brushes of strongyles (Fig. 13F).

Spicules. Phyllotriaenes (Fig. 13D) with short clads 40-(57.5)-87 $\mu \mathrm{m}(\mathrm{n}=8)$ and desmas quite rare; smooth and slightly curved strongyles (Fig. 13G) 315-(385, 54.3)-417 $\mu \mathrm{m} \times 2.5-(3.25,2.2)-7 \mu \mathrm{m}$, sometimes modified in oxeas; rhabds (Fig. $13 \mathrm{H}$ ) are straight with oxeote ends and long spines 7-(9.5)$14 \mu \mathrm{m}$. 

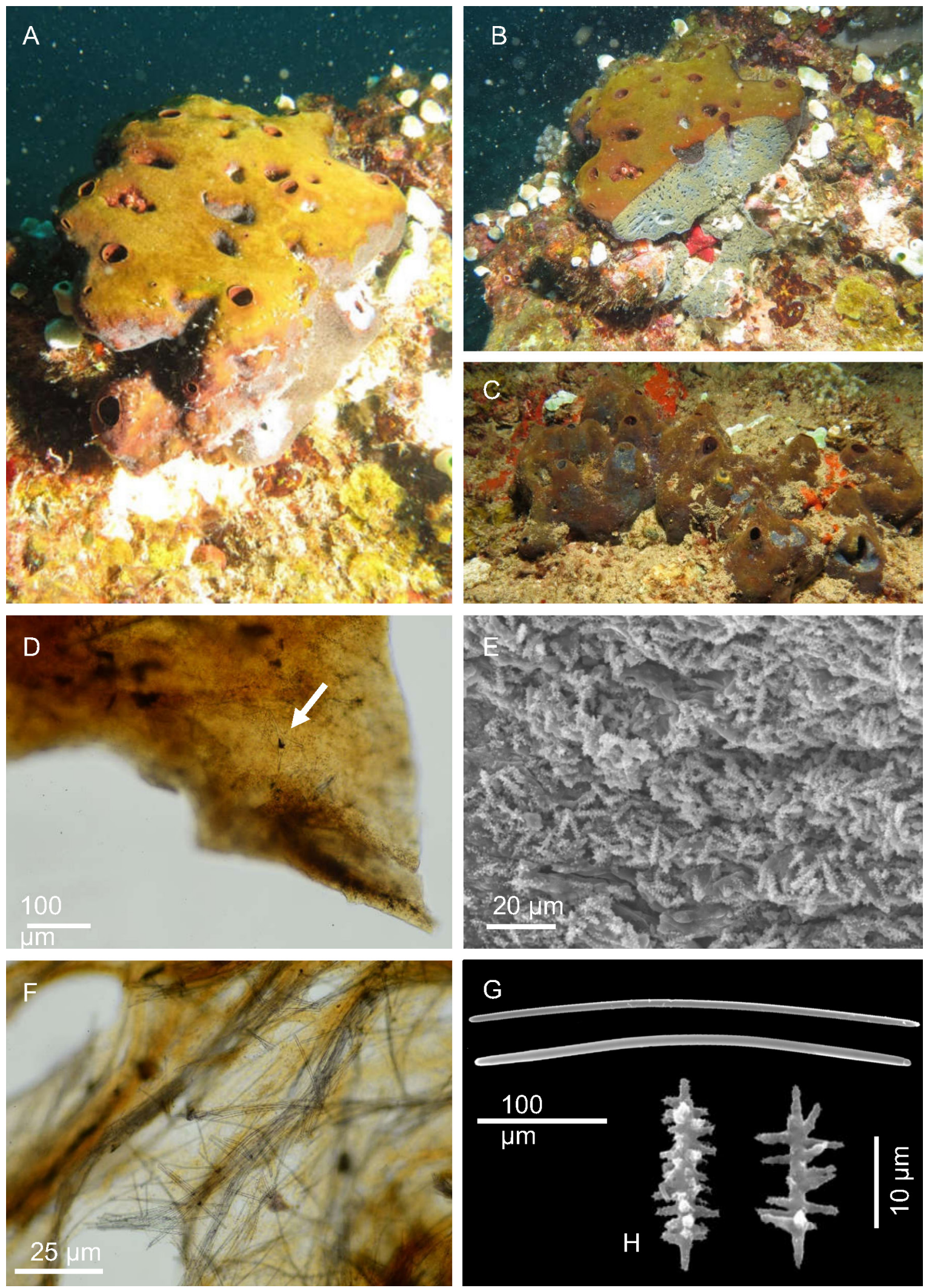

Fig. 13. Theonella conica (Kieschnick, 1896). A-B. The specimen PO2 in situ; in B a fresh cut highlights the blue colored choanosome. C. The specimen PO29 in situ. D. Ectosome with phyllotriaene (arrow) and rhabds. E. Crust of rhabds (SEM). F. Choanosomal skeleton. G. Strongyles. H. Straight rhabds. 


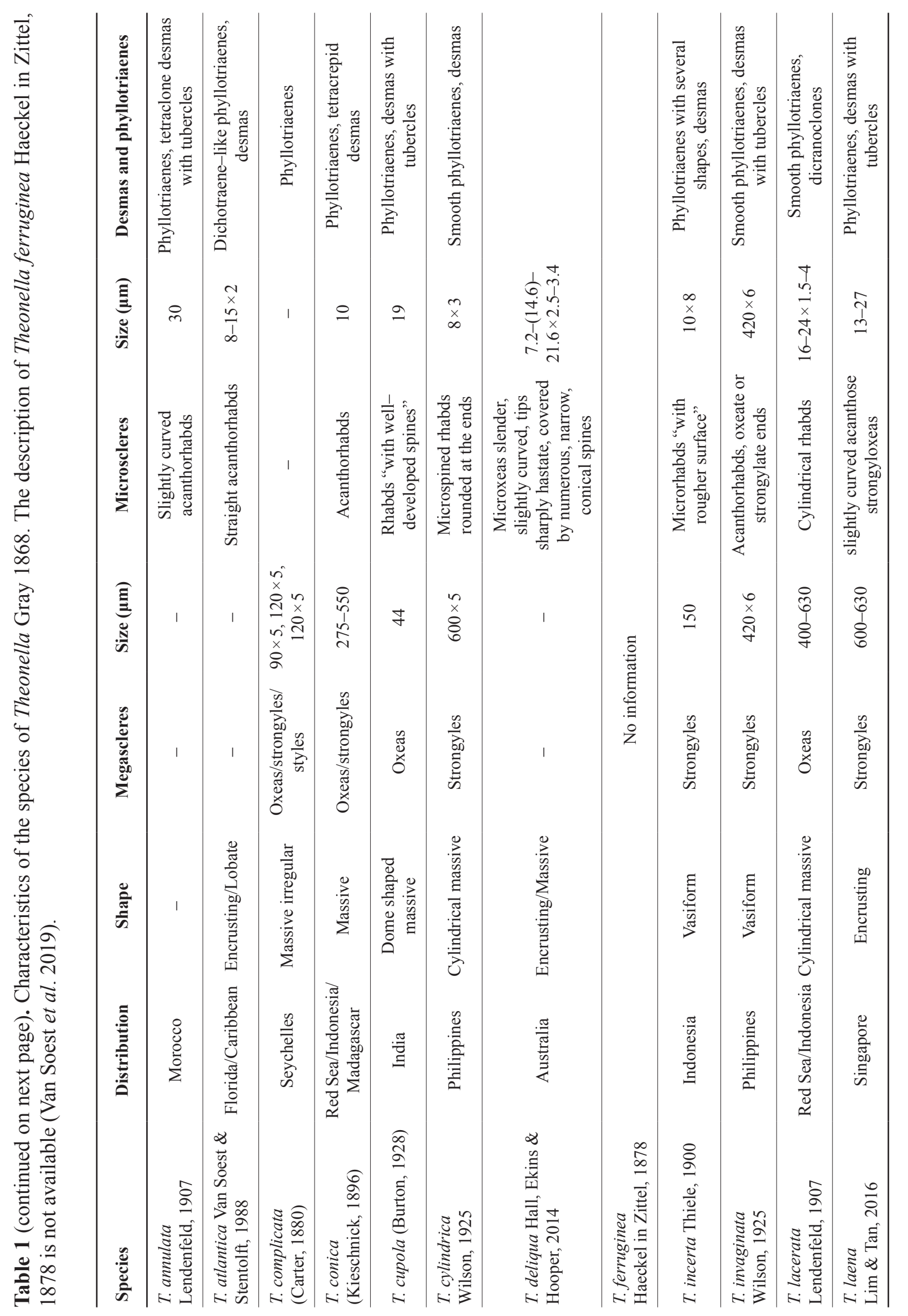




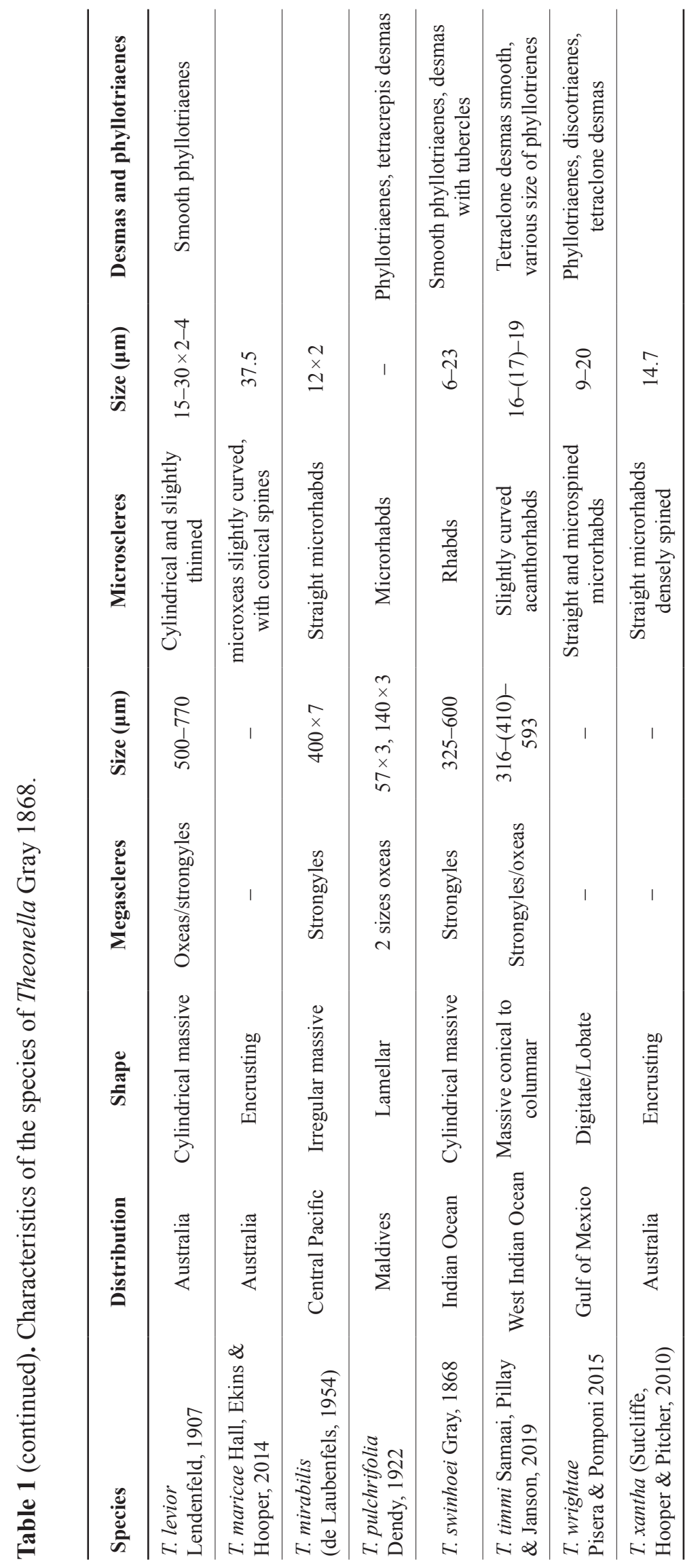




\section{Remarks}

The samples fall in the genus Theonella Lendenfeld, 1903 due to the presence of phyllotriaenes in the ectosome and the microscleres constituted by acanthorhabds.

To date, 20 species belong to the genus, three of which have records in the Atlantic Ocean (Table 1), while for Theonella ferruginea Haeckel in Zittel, 1878 the type locality is unknown (Van Soest et al. 2019).

Theonella deliqua Hall, Ekins \& Hooper, 2014, T. maricae Hall, Ekins \& Hooper, 2014 and T. xantha (Sutcliffe, Hooper \& Pitcher, 2010) are devoid of megascleres. Theonella lacerata Lendenfeld, 1907, T. cupola Burton, 1928 and T. pulchrifolia Dendy, 1922 differ from our samples because their megascleres are strictly oxeas. Theonella cylindrica Wilson, 1925, T. levior Lendenfeld, 1907 and T. laena Lim \& Tan, 2016 have longer strongyles (respectively 600, 500-770 and 600-630 $\mu \mathrm{m}$ long) while T. incerta Thiele, 1900 and $T$. complicata (Carter, 1880) have shorter strongyles (respectively 150 and $90-120 \mu \mathrm{m}$ long). Theonella invaginata Wilson, 1925, differs in the morphology (vasiform) and in the presence of microrhabs often with oxeate ends. Theonella swinhoei Gray, 1868 differs in its curved microrhabds and in the rounded extremity (often swollen) of the diactinal megascleres (tylotes) with respect to the straight ones in T. conica. Also, T. mirabilis (de Laubenfels, 1954), from the Marshall Islands, has straight acanthorhabds but a "dull carmine red" ectosome, microtuberculated surface and calthrops-like tetraclone desmas. In T. timmi Samaai, Pillay \& Janson, 2019, the microrhabds are bent.

The original description of $T$. conica is concise and no spicule measurements are given; the species was described from Halmahera, Indonesia, but records in the Indian Ocean and Red Sea are numerous (Van Soest et al. 2019). The material examined fits with the published descriptions of this species. In particular T. conica is described by Ilan et al. (2004) with strongyles, but no tylotes, and with straight acanthorhabds. They also underlined that the color of the internal part of this species is deep blue. Moreover, Lévi (1958) described T. conica from the Red Sea with spicules, fitting in shape and size with the present samples. In the examined specimens, very few desmas have been detected; they can be considered as rare spicules, not always produced by the sponge, as Thiele (1900) reported these spicules as being not numerous and scattered.

On the sample PO2, the hydroid Sphaerocoryne sp. (Class Hydrozoa, Phylum Cnidaria) was detected.

Theonella timmi Samaai, Pillay \& Janson, 2019

Fig. 14, Table 1

Theonella timmi Samaai, Pillay \& Janson, 2019: 25, fig. 9a-g.

\section{Material examined}

PONTA DO OURO • 1 fragment, irregular in shape, about $12 \times 6 \times 3 \mathrm{~cm}$, light blue; $26^{\circ} 49^{\prime 2} 29.579^{\prime \prime}$ S, 32॰53'51.072" E; Blacks; $18 \mathrm{~m}$ deep; 13 Nov. 2015; Cerrano leg.; PdO17 • 1 rounded, brown fragment of about $4 \mathrm{~cm} ; 2^{\circ} 45^{\prime} 41.04^{\prime \prime} \mathrm{S}, 32^{\circ} 54^{\prime} 7.144^{\prime \prime}$ E; Texas; $11 \mathrm{~m}$ deep; 15 Nov. 2015; Cerrano leg.; PdO23 - 1 flat fragment brown in color, about $8 \times 5 \times 1 \mathrm{~cm} ; 26^{\circ} 49^{\prime} 50.408^{\prime \prime} \mathrm{S}, 32^{\circ} 53^{\prime} 45.974^{\prime \prime} \mathrm{E}$; Doodles; 18 Nov. 2015; 18 m deep; Cerrano leg.; PdO26 • 2 flat, bluish fragments alcohol preserved, 2 fragments preserved dry; 2650'36.881" S, 32 54'54.471" E; Atlantis; 6 Feb. 2017; 40.7 m deep; Cerrano leg.; PO18 - several dried (bluish) and alcohol preserved fragments; 26 50'36.881" S, 32 54'54.475" E; Atlantis; 6 Feb. 2017; 40.7 m deep; Cerrano leg., PO19 • 1 small fragment of a few millimetres; 26 $6^{\circ} 9^{\prime} 17.512^{\prime \prime}$ S, 32 53'42.5" E; Kev's; 11 Feb. 2017; 22.4 m deep; Cerrano leg.; PO34 • small fragments; 26 $49^{\prime} 17.512^{\prime \prime}$ S, 32 $2^{\circ} 3^{\prime} 42.503^{\prime \prime}$ E; Kev's; 11 Feb. 2017; 22.4 m deep; Cerrano leg.; PO35 • small fragments; 26 49'17.512" S, 32 53'42.507" E; Kev's; 11 Feb. 2017; 22.4 m deep; Cerrano leg.; PO36 • very small fragment of a few millimitres; $26^{\circ} 49^{\prime} 19.119^{\prime \prime}$ S, 32 $54^{\prime} 9.82^{\prime \prime}$ E; Green bubbles; 17 Mar. 2017; 41.5 m deep; Cerrano leg.; PO88. 

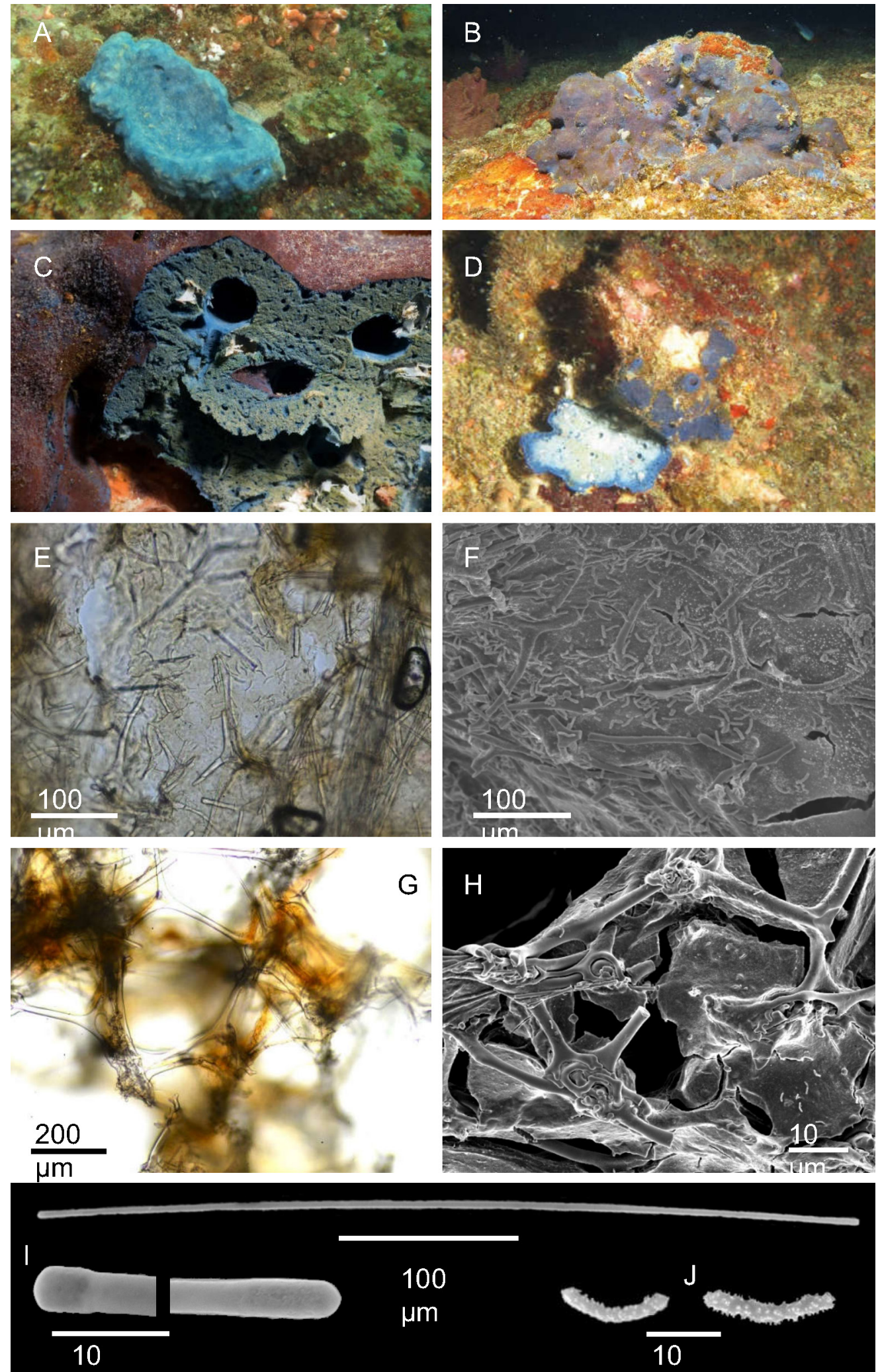

Fig. 14. Theonella timmi Samaai et al. 2019. A-D. The specimens PdO17, PO18, PO36 and PO19, respectively, in situ. E. Ectosome with phyllotriaenes and rhabds. F. Ectosomal skeleton with phyllotriaenes and rhabds (SEM). G. Tetraclone desmas of the choanosome. H. Tetraclone desmas of the choanosome (SEM). I. Strongyle and magnification of the tips. J. Bent rhabds. 


\section{Description}

Live sponge irregularly massive (Fig. 14 A-D). Color from light or vivid blue to brown; the surface is often covered by epibionths which hide the superficial sponge color. The samples preserved in alcohol are beige with a greenish shade. The surface is uneven, the consistence is tough and uncompressible.

SKELETON. Ectosome consisting of phyllotriaenes and strongyles organized in a layer with numerous rhabds (Fig. 14E-F). Choanosome formed by tetraclone desmas and brushes of strongyles (Fig. 14G-H).

Spicules. Phyllotriaenes 80-(139.1)-185 $\mu \mathrm{m}$ (Fig. 14E-F); desmas tuberculate and with rounded tips 125-(201.6)-300 $\times 15-20 \mu \mathrm{m}$ (Fig. 14G-H); smooth and slightly curved strongyles (Fig. 14I), 275$(355,77.2)-530 \mu \mathrm{m} \times 4.8-(6.25,1.3)-8 \mu \mathrm{m}$, often with slightly enlarged extremities; rhabds (Fig. 14J) are straight or bent in the middle and microspined, $8-(14.5)-19 \mu \mathrm{m}$.

\section{Remarks}

This sponge is widespread in the studied area; it fits with the species Theonella timmi as recently described by Samaai et al. (2019) from South Africa for its blue color, both interior and exterior, and for the shape and size of its spicules.

Order Clionaida Morrow \& Cárdenas, 2015

Family Clionaidae d'Orbigny, 1851

Genus Cliona Grant, 1826

Cliona grandis Samaai, Pillay \& Janson, 2019

Fig. 15

Cliona grandis Samaai, Pillay \& Janson, 2019: 12, fig. 3a-g.

\section{Material examined}

PONTADO OURO • 1 rounded fragment of about $3 \mathrm{~cm}$, preserved dry; $26^{\circ} 46^{\prime} 39.864^{\prime \prime} \mathrm{S}, 32^{\circ} 55^{\prime} 25.392^{\prime \prime} \mathrm{E}$; Cloud break; $36 \mathrm{~m}$ deep; 22 May 2015; Torsani leg.; IMG0830 • 1 small flat, rounded portion, preserved dry, of about $3 \mathrm{~cm} ; 2^{\circ} 49^{\prime} 29.579^{\prime \prime} \mathrm{S}, 32^{\circ} 53^{\prime} 50.819^{\prime \prime}$ E; Blacks; $18 \mathrm{~m}$ deep; 24 May 2015; Torsani leg.; IMG0913 - 5 fragments, preserved dry; the larger about $5 \times 2 \times 2 \mathrm{~cm} ; 26^{\circ} 49^{\prime} 29.579^{\prime \prime} \mathrm{S}, 32^{\circ} 53^{\prime} 50.819^{\prime \prime} \mathrm{E}$; Blacks; $17 \mathrm{~m}$ deep; 11 Nov. 2015; Cerrano leg.; PdO2 • 1 rounded fragment of $5 \mathrm{~cm}$ preserved dry; 26 $6^{\circ} 45^{\prime} 41.04^{\prime \prime} \mathrm{S}, 32^{\circ} 54^{\prime} 7.138^{\prime \prime}$ E; Texas; $11 \mathrm{~m}$ deep; 15 Nov. 2015; Cerrano leg.; PdO19 • 1 single fragment $5 \times 3 \times 2 \mathrm{~cm}$, preserved dry; 26 $49^{\prime} 50.408^{\prime \prime} \mathrm{S}, 32^{\circ} 53^{\prime} 45.974^{\prime \prime} \mathrm{E}$; Texas; $11 \mathrm{~m}$ deep; 15 Nov. 2015; Cerrano leg.; PdO22 • 3 fragments alcohol preserved; 26 45'41.04" S, 32 ${ }^{\circ} 54^{\prime} 7.141^{\prime \prime}$ E; Doodles; $17 \mathrm{~m}$ deep; 7 Feb. 2017; Cerrano leg.; PO22 • dried and alcohol preserved fragments; $26^{\circ} 49^{\prime} 50.408^{\prime \prime} \mathrm{S}$, 3253'45.977" E; Doodles; $17 \mathrm{~m}$ deep; 7 Feb. 2017; Cerrano leg.; PO23 • 3 alcohol preserved fragments, the larger about $7 \times 3 \times 1 \mathrm{~cm} ; 26^{\circ} 49^{\prime} 50.408^{\prime \prime} \mathrm{S}, 32^{\circ} 53^{\prime} 57.659^{\prime \prime} \mathrm{E}$; Close; $18.6 \mathrm{~m}$ deep; 9 Feb. 2017; Cerrano leg.; PO27 • very small fragments, alcohol preserved; $26^{\circ} 49^{\prime} 55.65^{\prime \prime} \mathrm{S}, 32^{\circ} 53^{\prime} 13.413^{\prime \prime} \mathrm{E}$; Three sisters; 23.9 m deep; 21 Feb. 2017; Cerrano leg.; PO64.

\section{Description}

Sponge in encrusting stage ( $\beta$ ) (IMG0830, PdO19, PdO22, PO22, PO23 and PO64) and massive stage $(\gamma)$ (IMGO913 and PO23). Two main chromatic varieties, shifting from ochre to orange (Fig. 15A-B) to pale or light yellow (Fig. 15C-D). Specimens, dried and alcohol preserved, are brown in color. The consistence of the papillae and of the $\gamma$-stage forms is firm and incompressible. The body of the $\gamma$-stage is cavernous. The sponges in the $\gamma$-stage are full of foreign material, also derived by their erosion and engulfing activity.

SKELETON. In the papillae, long and slim tylostyles are organized in palisade, in other parts the skeleton is more confused. 
Spicules. Tylostyles (Fig. 15E) with a prominent head (Fig. 15F); in numerous tylostyles the axial canal and the vesicle in the tylo are evident. They measure 295-(307.87)-345 $\mu \mathrm{m} \times 2.5-(6.7)-7.5 \mu \mathrm{m}$.

\section{Remarks}

This species was recently described by Samaai et al. (2019) from South Africa; it is widespread in the studied area where it develops a sort of biogenic fence up to $50 \mathrm{~cm}$ high.
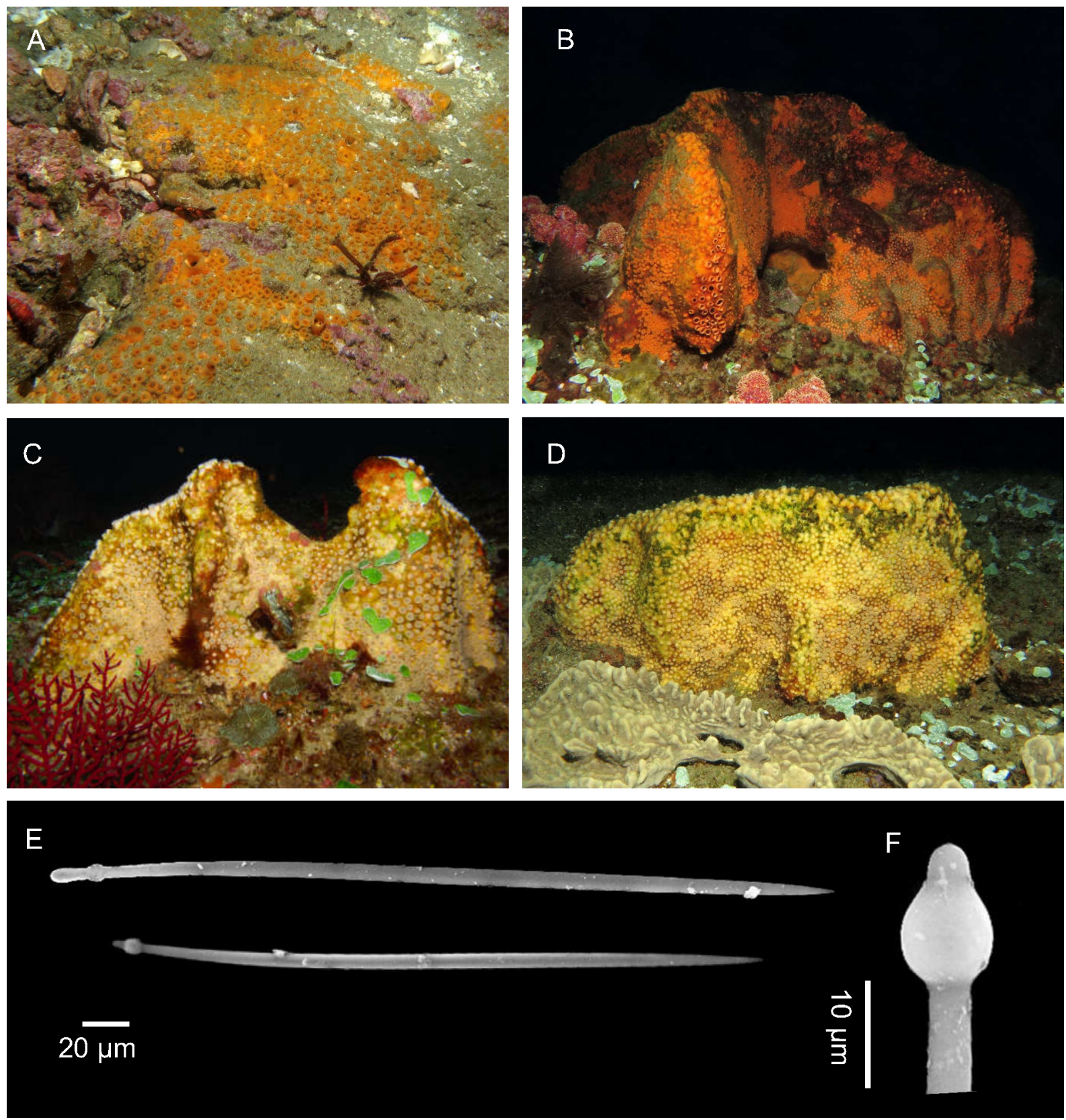

Fig. 15. Cliona grandis Samaai et al., 2019. A. Sponge in encrusting stage ( $\beta)$, PO64. B-D. Sponges in massive stage $(\gamma)$, respectively PO22, IMG830 and PO27. E. Tylostyles. F. Magnification of the tylostyle head. 
Genus Spheciospongia Marshall, 1892

Spheciospongia ndabazithe Samaai, Pillay \& Janson, 2019

Fig. 16

Spheciospongia ndabazithe Samaai, Pillay \& Janson, 2019: 19, fig. 6a-g.

\section{Material examined}

PONTA DO OURO 11 portion of $7 \times 3 \times 1 \mathrm{~cm} ; 26^{\circ} 46^{\prime} 38.829^{\prime \prime} \mathrm{S}, 32^{\circ} 54^{\prime} 17.384^{\prime \prime}$ E; Waynes; $40.6 \mathrm{~m}$ deep; 17 Feb. 2017; Cerrano leg.; PO52.

\section{Description}

Massive sponge (Fig. 16A-B), cup-shaped, light beige in the external and darker in the internal side. The alcohol preserved fragment is hard and incompressible, with a grey surface and a compact darker body.

SKeleton. Ectosome and choanosome confused, rich in sediments.
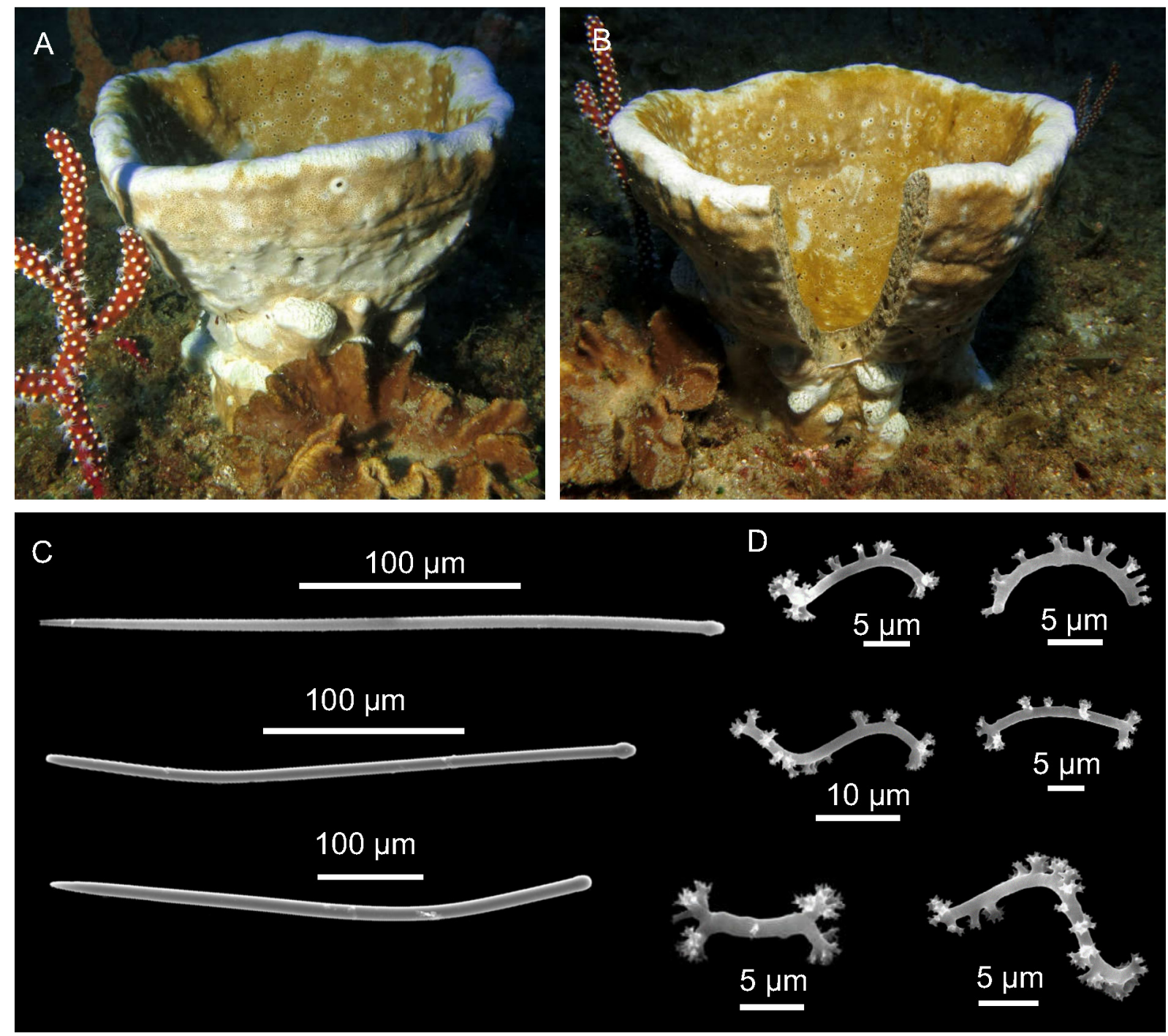

Fig. 16. Spheciospongia ndabazithe Samaai et al., 2019. A. Specimen PO52 in situ. B. The cut highlights the compact, darker choanosome. C. Tylostyles in different shapes. D. Spirasters variable in shapes. 
Spicules. Slim tylostyles sometimes curved towards the pointed tip (Fig. 16C), 250-(332) $-410 \mu \mathrm{m} \times 4-$ (7.3)-10 $\mu \mathrm{m}$ wide; sometimes they are modified in curved styles with acerate tips (Fig. 16C); spirasters variable in shapes (Fig. 16D) with an average length of $12.5 \mu \mathrm{m}$ : C-shaped with many spines along the convex side, straight and smooth with groups of spines at the extremities and longer, S-shaped spirasters with spines scattered along the axis.

\section{Remarks}

Our specimen perfectly fits the species recently described from South Africa by Samaai et al. (2019), with the exception of a larger variety of spirasters present in the specimen from Punta do Ouro.

\section{Spheciospongia vagabunda (Ridley, 1884)}

Fig. 17

Spirastrella vagabunda Ridley, 1884: 468, pl. 43 figs e, e’.

\section{Material examined}

PONTA DO OURO • 1 small portion, preserved dry; Blacks; 18 m deep; 13 Nov. 2015; Torsani leg.; PdO14.

\section{Description}

The sample, preserved dry, is a fragment collected from a sponge in the $\gamma$-stage (Fig. 17A); this and other observed specimens, very common in the area, are attached by a broad base, with one or more large

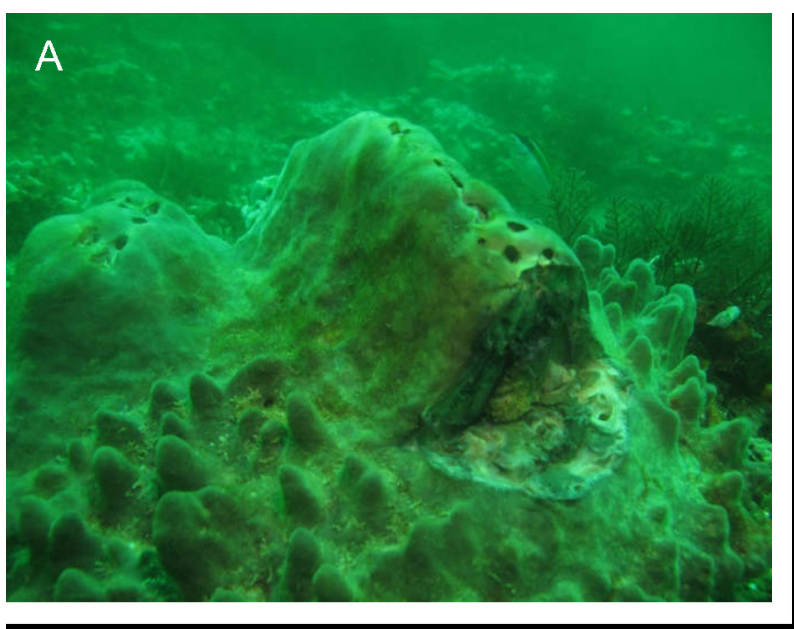

B

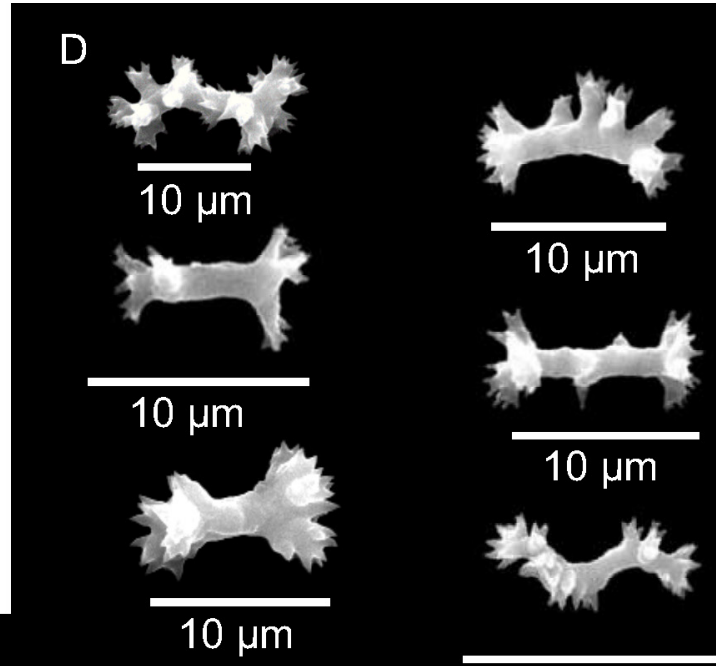

$20 \mu \mathrm{m}$

\section{$100 \mu \mathrm{m}$}

C

\section{$200 \mu \mathrm{m}$}

Fig. 17. Spheciospongia vagabunda (Ridley, 1884). A. Specimen PdO14 in situ. B. Big style. C. Small style. D. Spirasters. 
vents and numerous digitate protuberances; it is brown, with a smooth surface and a cavernous body; the consistence is tough and incompressible.

Skeleton. In the papillae, tylostyles are organized in palisade, in other parts the skeleton is more confused.

SPICULES. Big and straight styles (Fig. 17B), 450-(536.8, 48.8)-620×9-(10.7, 1.5)-13 $\mu \mathrm{m}$, rare tylostyles with slightly pointed tips; smaller styles (Fig. 17C), 240-(284.3, 30.3) $-310 \mu \mathrm{m} \times 5-(5.7,1.3)-8 \mu \mathrm{m}$, with acerate tips and, sometimes, tylostyle modifications; spirasters (Fig. 17D) are stout, with average length of $12.5 \mu \mathrm{m}$ and in several shapes: straight with spines at the extremities (amphiasters like), S-shaped wrapped with spines and slightly curved C-shaped spirasters.

\section{Remarks}

This species is widely distributed in the Indo-Pacific Ocean. Already recorded in the area (PulitzerFinali 1993; Barnes \& Bell 2002; Samaai et al. 2019).

Order Poecilosclerida Topsent, 1928

Family Chondropsidae Carter, 1886

Genus Chondropsis Carter, 1886

Chondropsis lamella (Lendenfeld, 1888)

Fig. 18, Table 2

Phoriospongia lamella Lendenfeld, 1888: 194.

\section{Material examined}

PONTA DO OURO • several fragments in alcohol, the larger $4 \times 2 \mathrm{~cm}$ and $8 \mathrm{~mm}$ thick; $26^{\circ} 49^{\prime} 50.408^{\prime \prime} \mathrm{S}$, 32 53'45.977" E; Doodle; $18 \mathrm{~m}$ deep; 14 Nov. 2015; Torsani leg.; PdO18c • 1 fragment, preserved dry, $6 \times 3 \times 2 \mathrm{~cm} ; 26^{\circ} 47^{\prime} 34.8^{\prime \prime} \mathrm{S}, 32^{\circ} 53^{\prime} 57.668^{\prime \prime} \mathrm{E}$; Close; 9 Feb. 2017; $18.6 \mathrm{~m}$ deep; Cerrano leg.; PO32 • 3 fragments, in alcohol, the larger about $3.5 \times 3 \times 2 \mathrm{~cm} ; 26^{\circ} 47^{\prime} 34.8^{\prime \prime} \mathrm{S}, 32^{\circ} 53^{\prime} 57.671^{\prime \prime} \mathrm{E}$; Close; 9 Feb. 2017; 18.6 m deep; Cerrano leg.; PO33 • 3 small fragments about $1 \mathrm{~cm}^{3} ; 26^{\circ} 49^{\prime} 55.65^{\prime \prime} \mathrm{S} 32^{\circ} 53^{\prime} 52.982^{\prime \prime} \mathrm{E}$; Tea Garden; 19.7 m deep; 6 Mar. 2017; Cerrano leg.; PO79.

\section{Description}

The sponge is lamellate, erect or massive (Fig. 18A-C). Oscules visible in the live specimens are small, slightly elevated and transparent (Fig. 18B). The sponge is brownish-orange in color and has an areolate surface (Fig. 18A). The samples preserved in alcohol are dark brown and have a stone-like consistence, but are friable and maintain the areolate surface; the abundant presence of sediment is clearly evident.

SKELETON. The ectosome and the choanosome are almost completely made by columns of grains, with brushes of spicules close to the surface.

SPICULES. Thin strongyles (Fig. 18D) with sometimes blunted tips (Fig. 18E), 90-(123.5, 15.3)-150 $\mu \mathrm{m} \times$ $3-(4.75,1)-6.5 \mu \mathrm{m}$; C-shaped sigmas of two sizes (Fig. 18F): 40-55 $\mu \mathrm{m}$ and 20-25 $\mu \mathrm{m}$.

\section{Remarks}

The examined material fits the original description of Chondropsis lamella (Lendenfeld, 1888) from Australia; only the color is different: brownish-orange in the examined samples, instead of greyishpink; this difference may be due to the nature of the foreign bodies used by the sponge in very large quantity to build its skeleton. Chondropsis lamella has an Indo-Pacific distribution (Van Soest et al. 2019) and has already been recorded in this area (Vacelet et al. 1976). Species characteristics of the genus Chondropsis Carter, 1886 from the original descriptions are resumed in Table 2. Chondropsis 
isimangaliso was recently described by Samaai et al. (2019) from eastern South Africa; it is similar in its external morphology to the specimens here described, but it differs in having a single category of sigmas.

On the sample PO79, the hydroid Zyzzyzus warreni Calder, 1988 (Class Hydrozoa, Phylum Cnidaria) was detected.
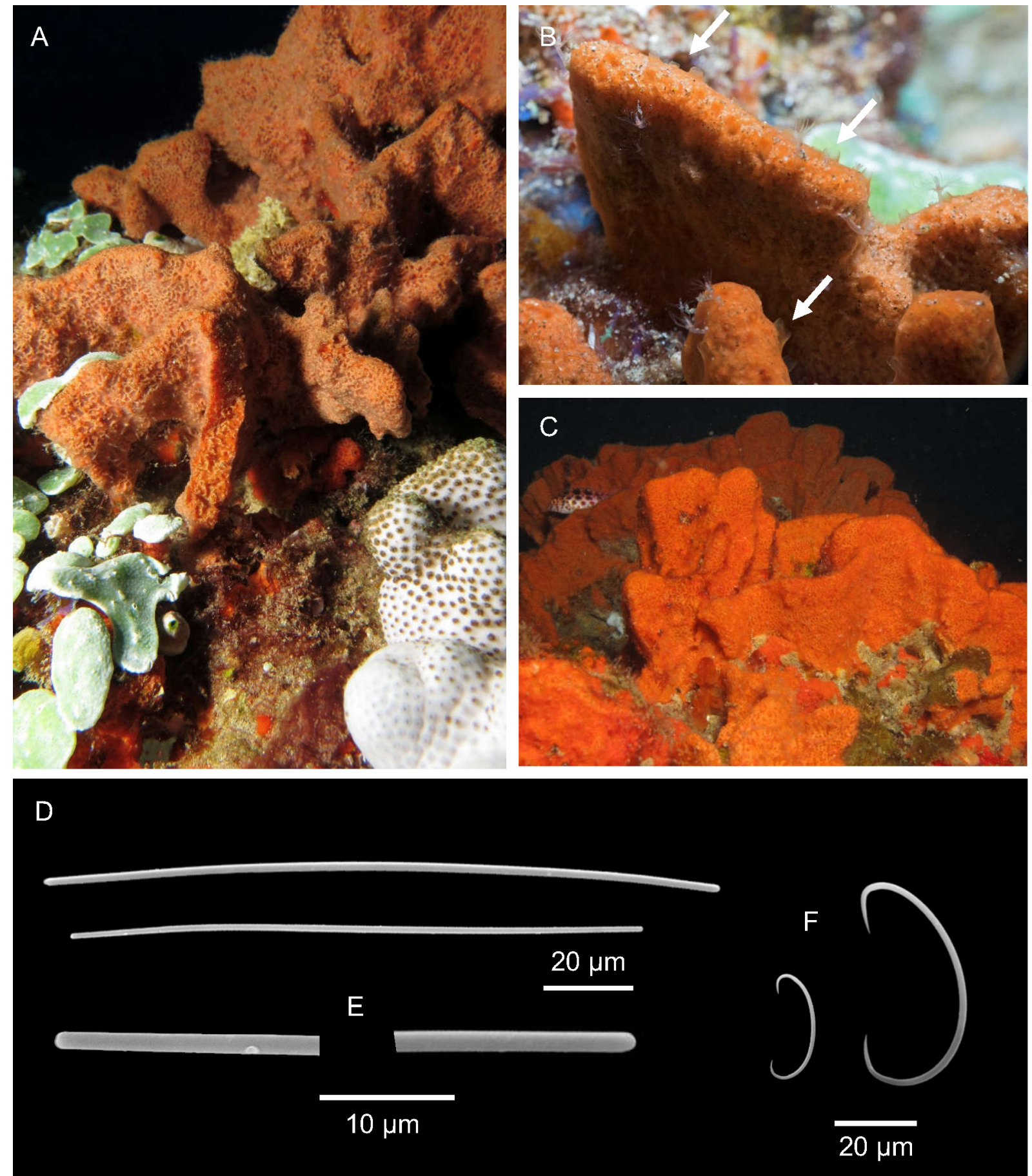

Fig. 18. Chondropsis lamella (Lendenfeld, 1888). A-C. Specimens in situ, respectively PO32, PO79 and PdO18c; in B the arrows point the slightly elevated oscules. D. Strongyles. E. Magnifications of the tips. F. Sigmas. 


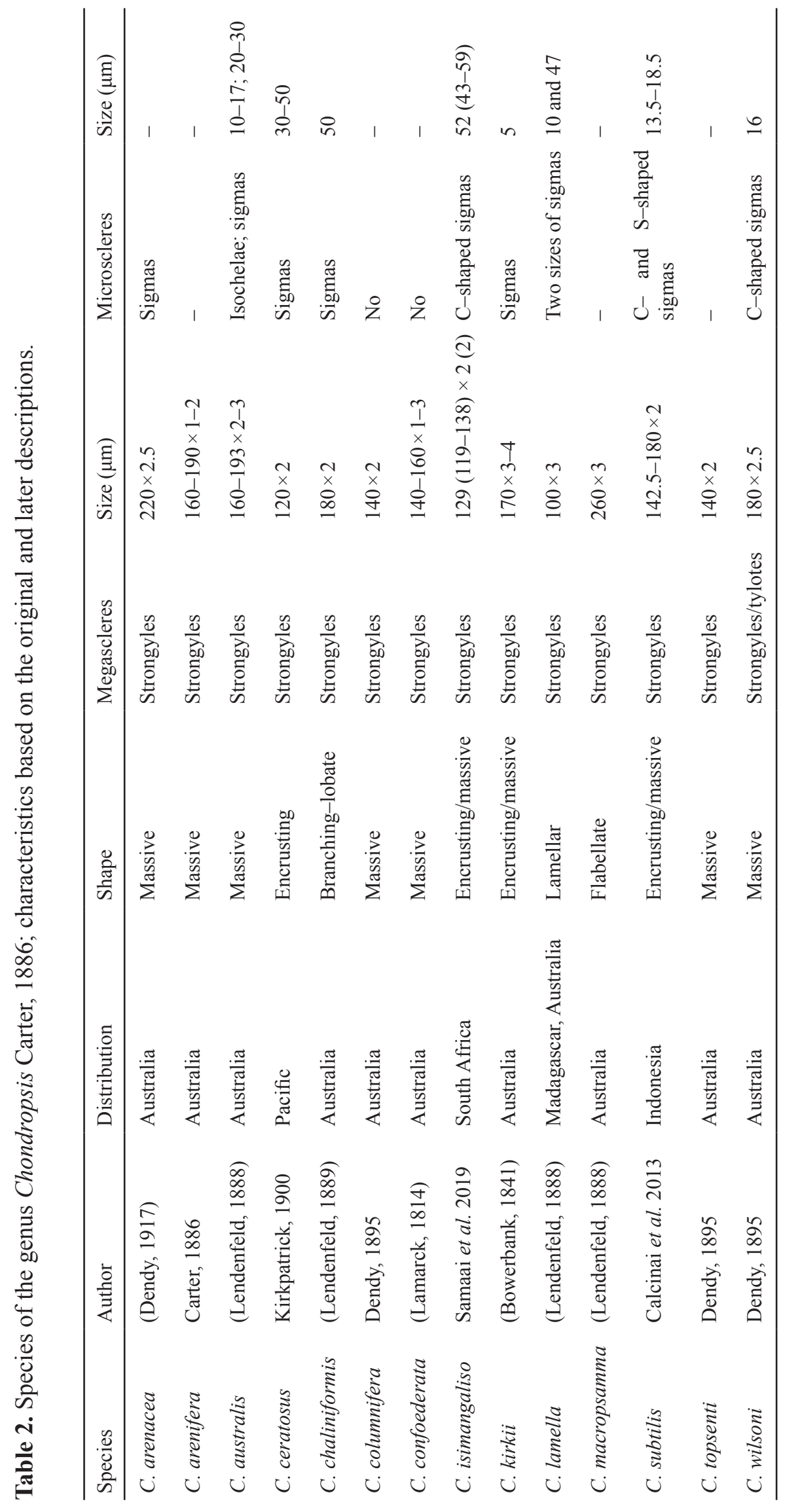


Genus Phoriospongia Marshall, 1880

Phoriospongia mozambiquensis Calcinai \& Belfiore sp. nov.

urn:1sid:zoobank.org:act:95AFED42-6EA0-471E-95BE-B805C4A31B27

Fig. 19, Table 3

\section{Diagnosis}

A red species of Phoriospongia characterized by styles with stepped tips, C and S-shaped sigmas, and isochelae.

\section{Etymology}

The specific name is derived from type locality.

\section{Material examined}

\section{Holotype}

PONTA DO OURO • fragment about $2 \times 2 \times 2 \mathrm{~cm} ; 26^{\circ} 49^{\prime} 50.408^{\prime \prime} \mathrm{S}, 32^{\circ} 53^{\prime} 45.97^{\prime \prime} \mathrm{E}$; Doodle; $17 \mathrm{~m}$ deep; 7 Feb. 2017; Cerrano leg.; MSNG 61420.

\section{Description}

The live sponge (Fig. 19A) is irregularly massive, bright red and covered by algal turf. The fragment preserved in alcohol changed the color to grey, with an uneven surface. It is very hard and friable and rich in sediments.

SKeLETON. The ectosome and the choanosome are almost completely constituted by columns of grains, with scattered spicules among the foreign bodies.

Spicules. Styles (Fig. 19B-C) with stepped tips, 260-(294.5, 24.2)-340 $\mu \mathrm{m} \times 2.5-(2.8,0.8)-5 \mu \mathrm{m}$; Cand S-shaped sigmas (Fig 19D), 28-(37.2)-42 $\mu \mathrm{m}$; arcuate isochelae (Fig. 19E), 9-(12.5)-14 $\mu \mathrm{m}$.

\section{Remarks}

This sponge belongs to the genus Phoriospongia, which is characterized by "skeletal columns cored by styles and foreign material [...]; sigmas usually present” (Van Soest 2002).
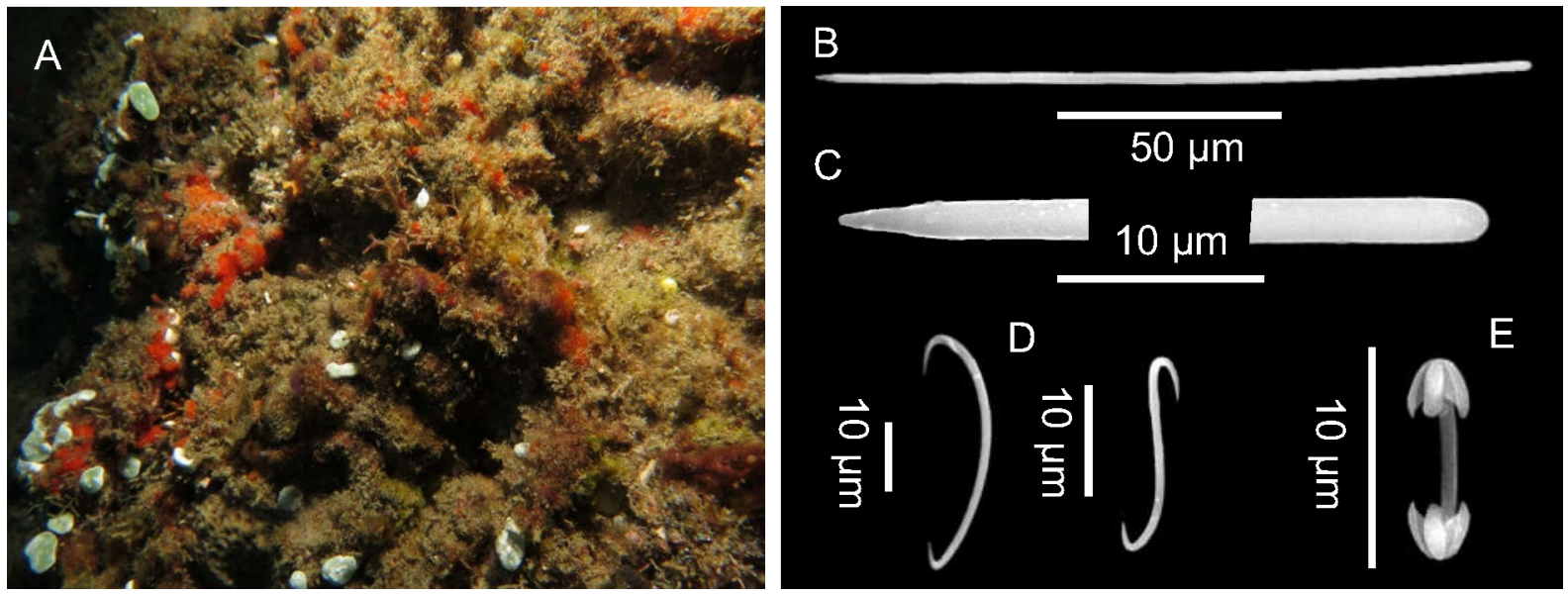

Fig. 19. Phoriospongia mozambiquensis Calcinai \& Belfiore sp. nov. A. The holotype MSNG 61420 in situ. B. Style. C. Magnifications of the tips. D. C- and S-shaped sigmas. E. Arcuate isochela. 


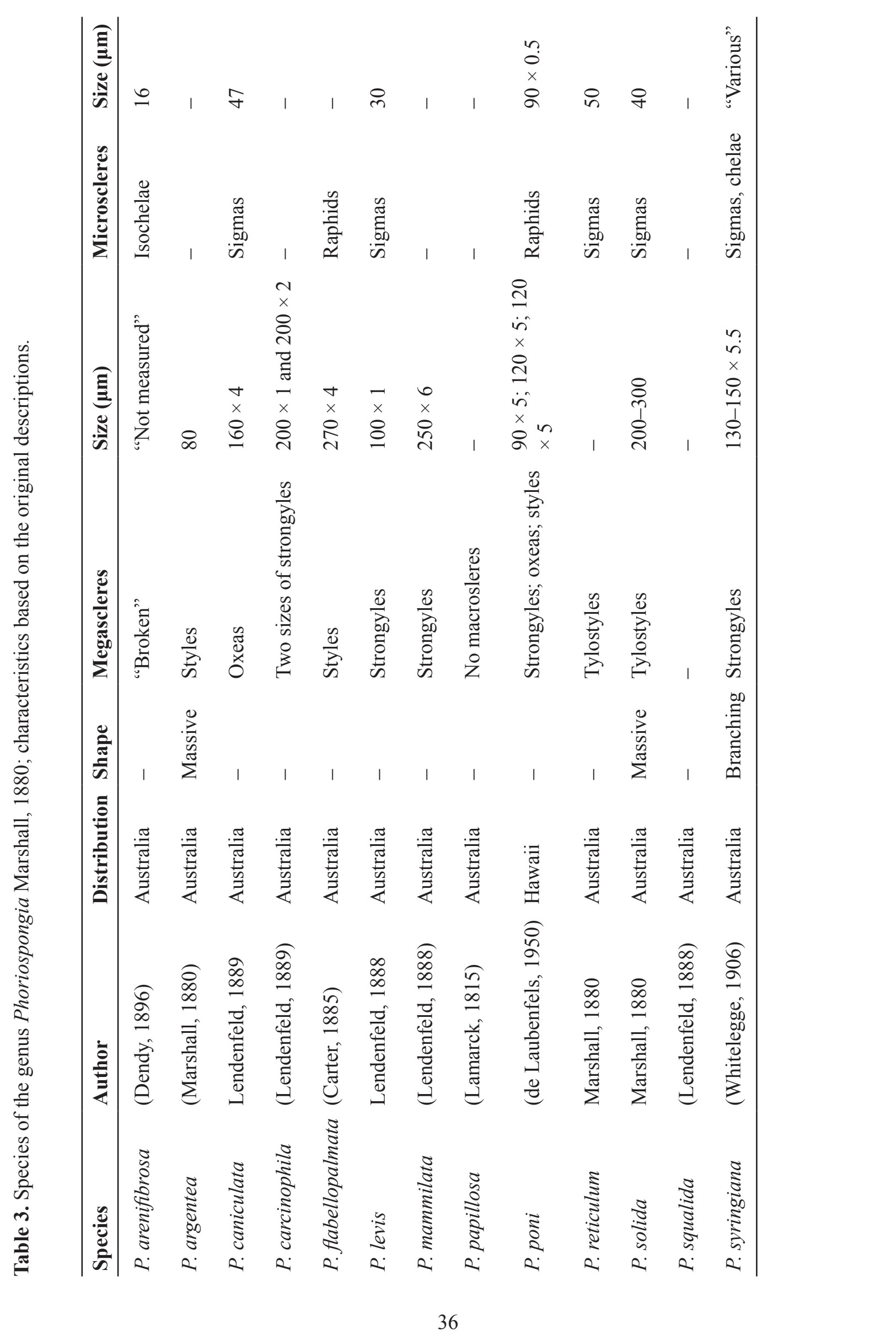


The genus Phoriospongia Marshall, 1880 includes 13 species, all with an Indo-Pacific Ocean distribution, mainly from Australia (Van Soest et al. 2019). Due to the nature of the skeleton and to the capacity of the sponge to incorporate foreign bodies, it is difficult to clearly detect the skeleton organization, and most of the original descriptions are inadequate (Table 3). Phoriospongia arenifibrosa (Dendy, 1896) differs from this new species due to the absence of megascleres and to the morphology (erect, palmo-digitate sponge). Phoriospongia argentea (Marshall, 1880) has shorter styles $(80 \mu \mathrm{m})$ and does not have any microscleres. Phoriospongia canaliculata Lendenfeld, 1889 has oxeas instead of styles. Phoriospongia reticulum (Marshall, 1880) and P. solida Marshall, 1880 differ in the possession of tylostyles. Phoriospongia flabellopalmata (Carter, 1885) shows a smooth and even surface, with longer styles and raphides as microscleres. Phoriospongia carcinophila (Lendenfeld, 1889), P. levis Lendenfeld, 1888, P. mammillata (Lendenfeld, 1888) and P. syringiana (Whitelegge, 1906) have different megascleres, i.e., strongyles instead of styles. The description of P. papillosa (Lamarck, 1815) is inadequate and neither megascleres nor microscleres are reported. Phoriospongia poni (De Laubenfeld, 1950), described from the Hawaii Islands, has three kinds of megascleres, i.e., oxeas, strongyles and styles. In the original description, P. squalida Lendenfeld, 1888, spicules are not described and, moreover, the sponge is reported as erect and tubular.

Considering the affinities between Phoriospongia and Chondropsis, the species of the latter genus have been used for a comparison, but none was found to fit the new species from Mozambique (Table 2).

Family Iotrochotidae Dendy, 1922

Genus Iotrochota Ridley, 1884

Iotrochota cf. sinki Samaai Pillay \& Janson, 2019

Fig. 20

Iotrochota sinki Samaai et al. 2019: 40, fig. 16a-g.

\section{Material examined}

PONTA DO OURO • 3 fragments about $1 \mathrm{~cm}^{3} ; 26^{\circ} 46^{\prime} 55.65^{\prime \prime} \mathrm{S}, 32^{\circ} 54^{\prime} 13.41^{\prime \prime} \mathrm{E}$; Three Sisters; $24.2 \mathrm{~m}$ deep; 22 Mar. 2017; Cerrano leg.; PO85 • 1 single fragment $4.5 \times 2 \times 1 \mathrm{~cm} ; 26^{\circ} 49^{\prime} 17.512^{\prime \prime} \mathrm{S}$, 3253'42.5" E; Kev's; 26.2 m deep; 22 Apr. 2017; Cerrano leg.; PO100.

\section{Description}

Sponge massively encrusting or massive (Fig. 20A-B). On the surface, the exhalant system is evident as a vein-like pattern converging on the oscula (Fig. 20B). The color is yellow, mottled with brick red patches (Fig. 20A-B). In alcohol, the sponge changes its color to brown. Where the ectosome is preserved, the surface is smooth and the areolate surface still evident. The consistence is firm and incompressible.

SKELETON. The ectosome consists of a layer of compact smooth styles, easily detachable. The choanosome presents a reticulum of multispicular primary fibers, between 70 and $150 \mu \mathrm{m}$, with meshes up to $300 \mu \mathrm{m}$, and secondary multispicular fibers, $30-50 \mu \mathrm{m}$ in section, with smooth, interstitial styles.

Spicules. Styles (Fig. 20C), 140-(167, 14.8)-195 $\mu \mathrm{m} \times 5-(6.1,0.8)-7.5 \mu \mathrm{m}$, bent in the proximal part, closer to the head, the tips acerate or mucronate; thin and straight styles (Fig. 20D) $220-(232.5,7.7)-245 \mu \mathrm{m} \times$ $3-(4.5,0.6)-5 \mu \mathrm{m}$; less common and slightly curved, strongyles (Fig. 20E) $150-(170)-190 \mu \mathrm{m} \times 5-$ (6.5)-8 $\mu \mathrm{m}$; birotulas (Fig. 20F) 12-(16, 1.3)-17 $\mu \mathrm{m}$. 


\section{Remarks}

The specimens belong to the genus Iotrochota Ridley, 1884, due to the structure of the choanosome with multispicular fibers and the presence of two different kinds of megascleres and birotulas. It comprises 15 species, with nine spread in the Indo-Pacific Ocean. Iotrochota nigra (Baer, 1906) was recorded in the same geographic area (East Africa), but differs in morphology and color, and, above all, in the absence of birotulas. Iotrochota baculifera Rildley, 1884 and I. purpurea (Bowerbank, 1875) are from the West Pacific Ocean, I. pella (de Laubenfles, 1954) and I. iota (de Laubenfels, 1954) are from Micronesia, I. protea (de Laubenfels, 1950) is from Hawaii, I. membranacea (Esper, 1794) is recorded in the East Pacific Ocean, I. coccinea (Carter, 1886) is from Australia. All these species are massive, dark violetblack colored and differ from the Mozambican specimens in spicule sizes and morphology. Iotrochota sinki, recently described by Samaai et al. (2019) from South Africa, perfectly matches the specimens from Mozambique, especially in the external morphology. Some differences are in the megascleres, as in I. sinki, styles in three size classes are recognized, and strongyles (that are considered rare) are longer $(168-281 \times 4 \mu \mathrm{m})$.

The species here described fits the description of Iotrochota birotulata (Higgin, 1877), recorded many times in the Caribbean Sea and in Brazil (Van Soest et al. 2019), in the general external morphology
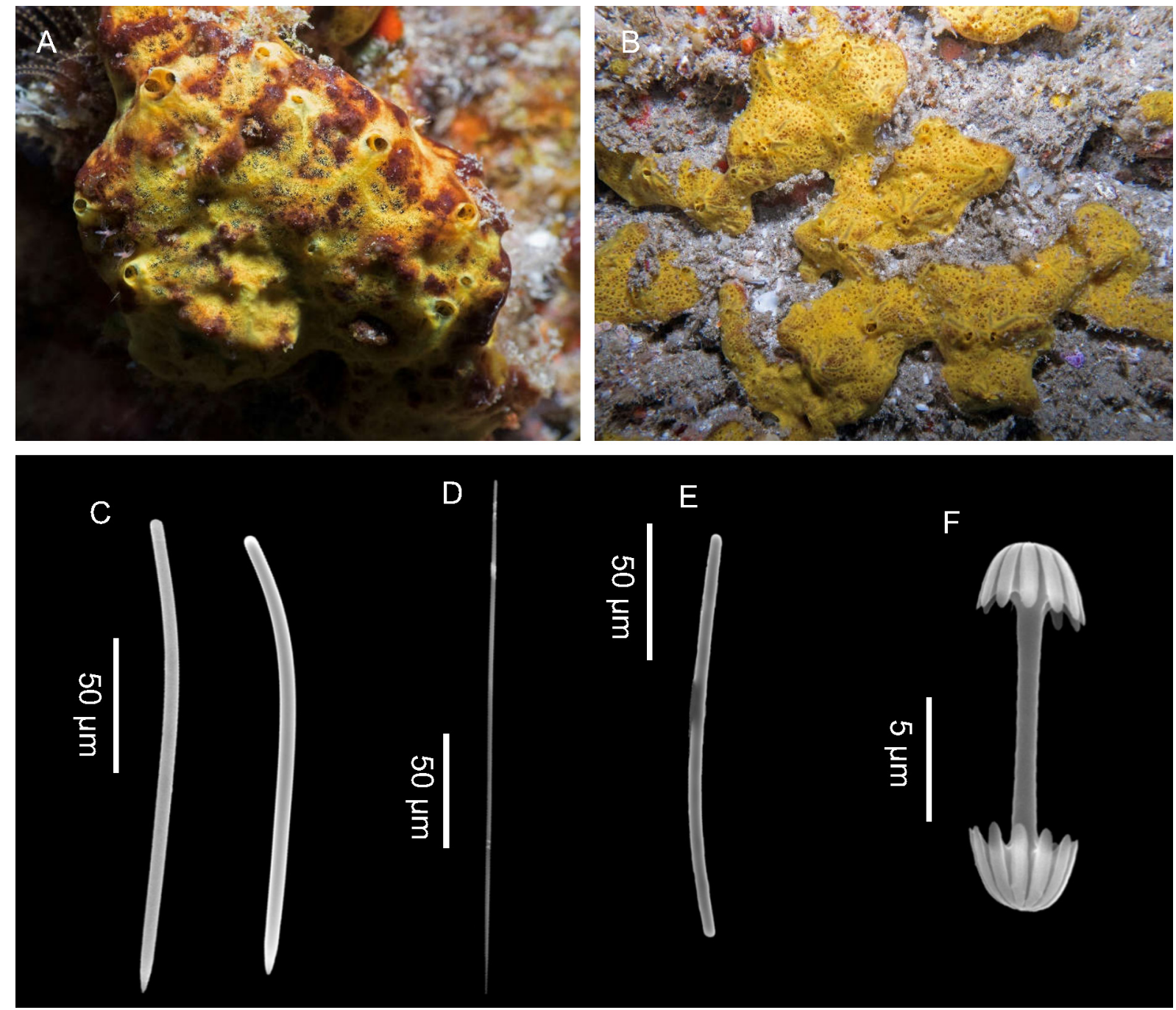

Fig. 20. Iotrochota cf. sinki Samaai et al. 2019. A-B. Massive (PO85) and encrusting (PO100) specimens in situ. C. Styles. D. Thin and straight style. E. Slightly curved strongyle. F. Birotula. 
and its spicule features. Iotrochota birotulata shows a highly variable morphology, often erect, and is dark purple colored. The Mozambican specimens are characterized by the presence of two kind of styles (typical of the species of this genus) and strongyles are intermingled throughout the sponge; even the spicule dimensions fit those of the type species I. birotulata. Considering the disjunct geographic distribution of this record with respect to I. birotulata, it is convenient to identify the Mozambican species as Iotrochota cf. sinki Samai et al. 2019 pending further molecular studies that could clarify its cryptogenic nature. The specimen PO85 (Fig. 20A) is in association with Zyzzyzus warreni Calder, 1988 (Class Hydrozoa, Phylum Cnidaria).

Family Microcionidae Carter, 1875

Genus Clathria Schmidt, 1862

Clathria (Thalysias) Duchassaing \& Michelotti, 1864

Clathria (Thalysias) hirsuta Hooper \& Levi, 1993

Fig. 21

Clathria hirsuta Hooper \& Levi, 1993: 1259, figs 19-20.

\section{Material examined}

PONTA DO OURO • 1 very small sample covering a hydroid; $26^{\circ} 49^{\prime} 29.579^{\prime \prime} \mathrm{S}, 32^{\circ} 53^{\prime} 51.072^{\prime \prime} \mathrm{E}$; Blacks; 19.2 m deep; 4 Feb. 2017; Cerrano leg.; PO10 • 1 small fragment; 26²49'16.561" S, 3253'52.979" E; Tea Garden; 19.7 m deep; 6 Mar. 2017; Cerrano leg.; PO78.

\section{Description}

The sponge is massive (Fig. 21A-B), digitiform and arborescent (Fig. 21C). The exhalant channels converge in numerous, large oscula (Fig. 21A-B). The color may vary from bright orange to vivid red (Fig. $21 \mathrm{~A}-\mathrm{C}$ ). Both samples preserved in alcohol changed their color to beige. The surface is verrucose and the consistence is elastic.

Skeleton. The ectosome consists of a layer of small styles. The choanosome is formed by an irregular reticulation from pauci- to multispicular primary fibers, $52-73 \mu \mathrm{m}$ in section, and secondary unispicular fibers, $24-41 \mu \mathrm{m}$. Both are spongin rich and are cored by smooth styles. Echinating acanthostyles are present on the primary fibers (Fig. 21D).

Sicules. Smooth and straight styles (Fig. 21E), sometimes modified in subtylostyles, 82.5-(93.25, 11.8)$137.5 \mu \mathrm{m} \times 4-(5.2,0.7)-6 \mu \mathrm{m}$; smooth and slightly curved styles (Fig. 21F), 70-(109.5, 23.4)-147 $\mu \mathrm{m} \times$ 4.5-(5.2, 0.7)-6.1 $\mu \mathrm{m}$; straight acanthostyles (Fig. 21G) with sharp spines on the terminal parts, close to the tips and scattered on the head, $40-(56.3,10.3)-72 \mu \mathrm{m}$; raphidiform toxas (Fig. $21 \mathrm{H})$ slightly curved in the middle, $100-(104.5)-120 \mu \mathrm{m} \times 4.75-(6)-7.5 \mu \mathrm{m}$; palmate chelae (Fig. 21I) 5-7.5 $\mu \mathrm{m}$.

\section{Remarks}

Clathria (Thalysias) hirsuta Hooper \& Levi, 1993 was exclusively known from New Caledonia and Australia (Great Barrier Reef); this is the first record in the Indian Ocean. The spicule shape, size and the morphology fit the original description of the species. However, Hooper \& Levi (1993) recognized two distinct populations, with some morphological differences, one from Queensland and one from New Caledonia. The morphological characters (especially spicule size) make the specimens, here examined, closer to the population from New Caledonia.

On the specimen PO78 the hydroid Zyzzyzus warreni Calder, 1988 (Class Hydrozoa, Phylum Cnidaria) was detected. 

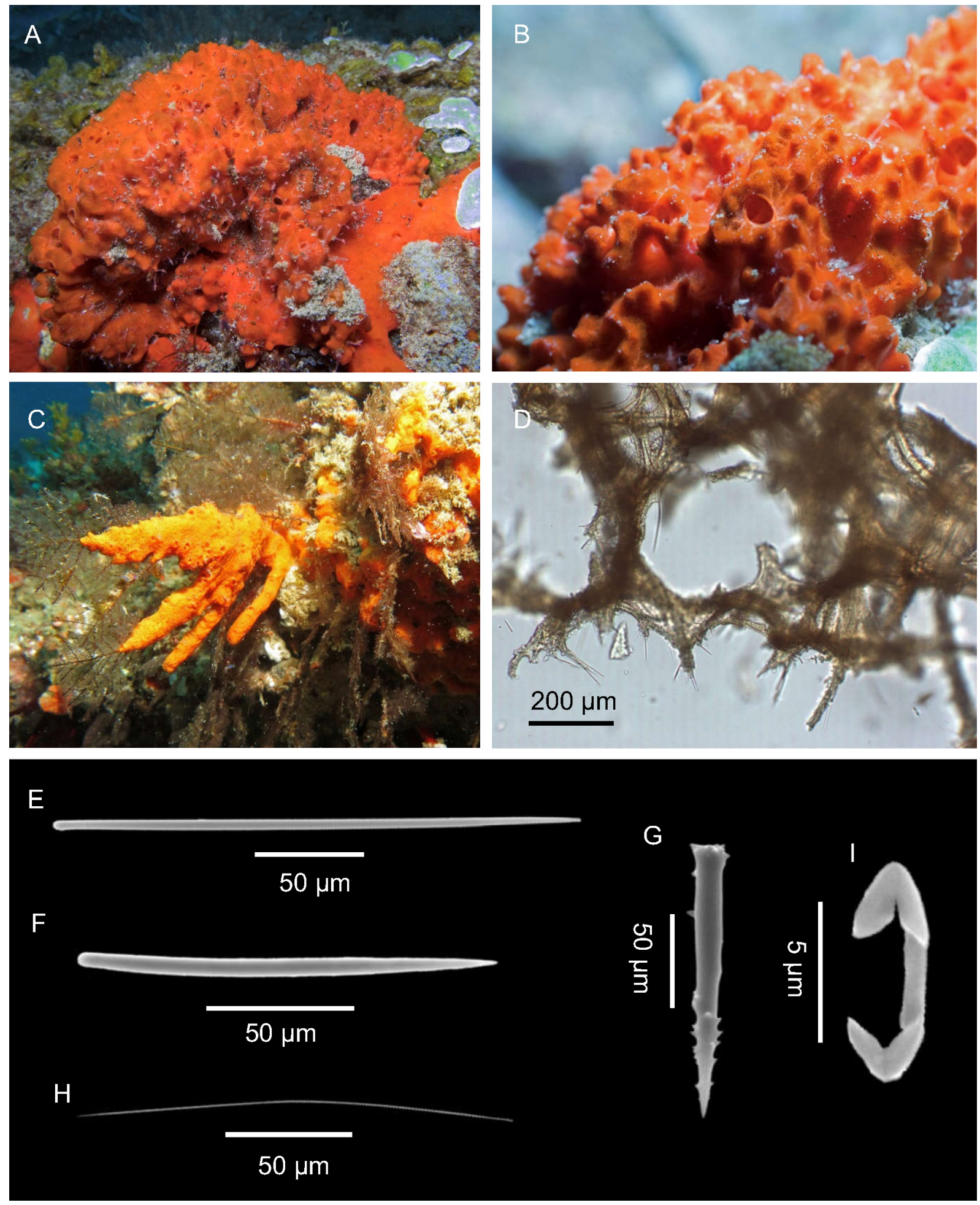

Fig. 21. Clathria (Thalysias) hirsuta Hooper \& Levi, 1993. A-B. Massive specimen PO78 in situ. C. Digitiform specimen PO10 in situ. D. Choanosome. E. Smooth and straight style. F. Smooth and slightly curved style. G. Straight acanthostyles. H. Raphidiform toxa. I. Palmate chela. 
Clathria (Thalysias) vulpina (Lamarck, 1814)

Fig. 22

Spongia vulpina Lamarck, 1814: 449.

\title{
Material examined
}

PONTA DO OURO • 1 sample preserved dry; 26 46'39.864" S, 32 $55^{\prime} 25.319^{\prime \prime}$ E; Cloud break; $34 \mathrm{~m}$ deep; 22 May 2015; Torsani leg.; IMG0826 • several fragments, the larger about $6 \mathrm{~cm}$ long; 26 $49^{\prime} 17.512^{\prime \prime}$ S, 3253'42.511" E; Kev's; 23.4 m deep; 3 Feb. 2017; Cerrano leg.; PO3.

\section{Description}

The live sponge is massive, with rounded conules covering the surface (Fig. 22A). The color is redorange. The fragments preserved in alcohol are beige in color; they have a digitate-conulose surface and a very firm consistence.

Skeleton. The ectosome consists of a paratangential layer of thin styles (Fig. 22B). The choanosome (Fig. 22C) is made by a reticulation of multispicular primary fibers, $70-125 \mu \mathrm{m}$ in section, and secondary fibers, 23-35 $\mu \mathrm{m}$, forming irregularly rounded meshes around $150 \mu \mathrm{m}$ wide. The fibers have a core of styles and are echinated by acanthostyles.

SpICULES. Slightly curved and smooth styles (Fig. 22D), sometimes straight, 145-(176.5, 21.4)-210 $\mu \mathrm{m} \times 6-(7,1.1)-9.5 \mu \mathrm{m}$; longer and straight subtylote styles (Fig. 22E), microspined or smooth on the head, $198.5-(230,15.5)-250 \mu \mathrm{m} \times 4.5-(6.5,0.8)-7.5 \mu \mathrm{m}$; subtylote acanthostyles (Fig. 22F), with smooth neck, $47.5-(51,4.9)-72.5 \mu \mathrm{m}$; very thin toxas (Fig. $22 \mathrm{G}$ ), bent in the middle, $143-181 \mu \mathrm{m}$; palmate isochelae (Fig. 22H) 11.3-14.6 $\mu \mathrm{m}$.

\section{Remarks}

The specimens fit the original description of Clathria (Thalysias) vulpina (Lamarck, 1814) from Australia. The species has already been found in the area (Thomas 1979). On the specimen PO3, the hydroid Zyzzyzus warreni Calder, 1988 (Class Hydrozoa, Phylum Cnidaria) grew.

\author{
Family Tedaniidae Ridley \& Dendy, 1886 \\ Genus Tedania Gray, 1867
}

\section{Tedania sp.}

Fig. 23

\section{Material examined}

PONTA DO OURO • 1 fragment; 26²9'29.579" S, 3253'50.891" E; Blacks; 17 m deep; 11 Nov. 2015; Torsani leg.; PdO5.

\section{Description}

No available photos of the live sponge. The dried sample is a thin dirty-white lamina $(20 \times 30 \times 5 \mathrm{~mm})$, smooth and fragile.

Skeleton. In the fragment, it was impossible to distinguish ectosome from choanosome. The skeleton looks quite confused, with scattered spicules that sometimes become organized in loose tracts of tylotes.

SpICULES. Smooth styles (Fig. 23A), bent in the first third of the axis and with blunt tips, 255-(281.5, $7.5)-285 \mu \mathrm{m} \times 3.75-(4.5,0.4)-5 \mu \mathrm{m}$; slightly curved tylotes (Fig. $23 \mathrm{~B}$ ), with slightly accentuated and 



D

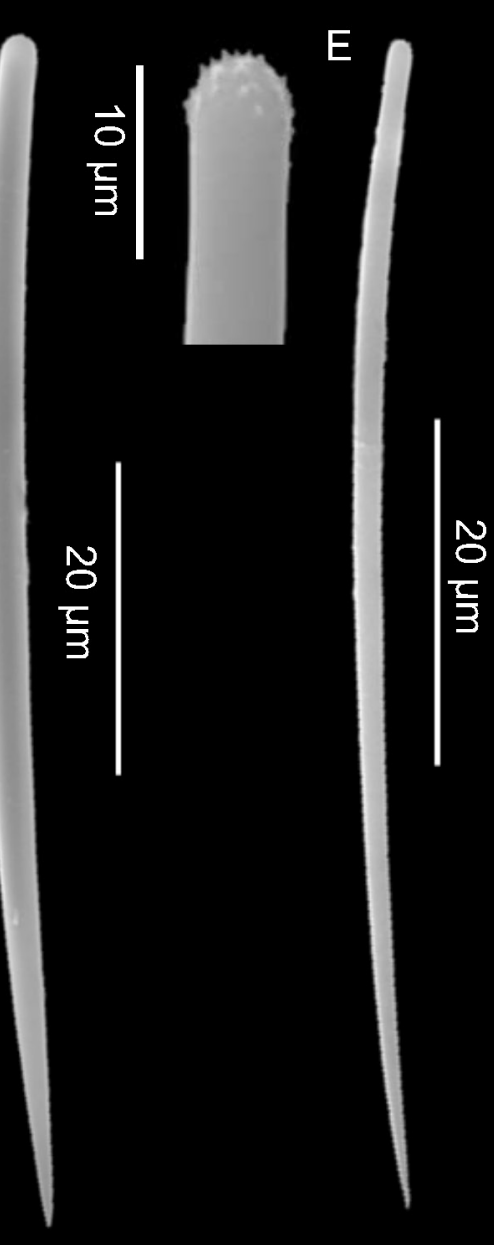

한

$20 \mu \mathrm{m}$

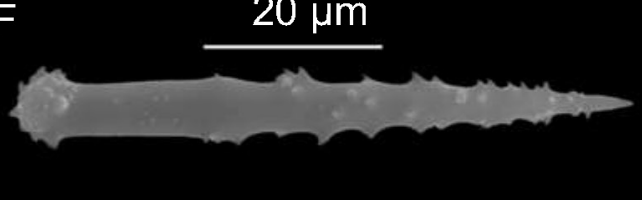

\section{$20 \mu \mathrm{m}$}

G
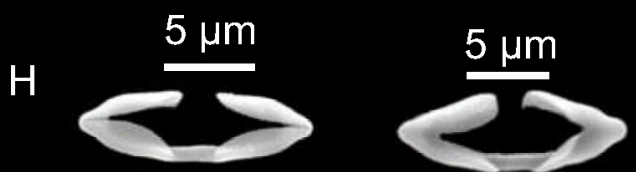

옹

Fig. 22. Clathria (Thalysias) vulpina (Lamarck, 1814). A. Specimen IMG0826 in situ. B. Ectosomal skeleton (SEM). C. Choanosomal skeleton (SEM). D. Slightly curved style and magnification of its smooth head. E. Longer style and magnification of its microspined head. F. Acanthostyle and magnification of its microspined head. G. Very thin toxa. H. Palmate isochelas. 
smooth tips, $245-(267.5,25.1)-335 \mu \mathrm{m} \times 2.5-(3,0.8)-5 \mu \mathrm{m}$; onychaetes (Fig. $23 \mathrm{C})$ with acerate tips and usually with a swelling close to one tip, 77.5-(125)-142.5 $\mu \mathrm{m}$.

\section{Remarks}

The specimen belongs to the genus Tedania Gray, 1867 based on the presence of two kinds of megascleres, one monoactinial and one diactinial, and onychaetes; the assignment to the subgenus is tricky: species belonging to the subgenus Tedania Gray, 1867 have, generally, spined tylotes, but, e.g., Tedania (Tedania) toxicalis De Laubenfels, 1930 has smooth tylotes (see also Desqueyroux \& Van Soest 1996: 54); Tedaniopsis Dendy, 1924 has longer choanosomal megascleres (> $350 \mu \mathrm{m})$ and Trachytedania Ridley, 1881 has mucronate or oxeote tornotes as ectosomal megascleres. As a consequence and also considering the reduced size of the specimen, preventing any additional investigation, we prefer not to attribute any subgenus or species to this sponge and describe it as Tedania sp.

Order Suberitida Chombard \& Boury-Esnault, 1999

Family Halicondriidae Gray, 1867

Genus Ciocalypta Bowerbank, 1873

Ciocalypta heterostyla Hentschel, 1912

Fig. 24

Ciocalypta heterostyla Hentschel, 1912: 424, pl. 14, fig. 3, pl. 21, fig. 58.

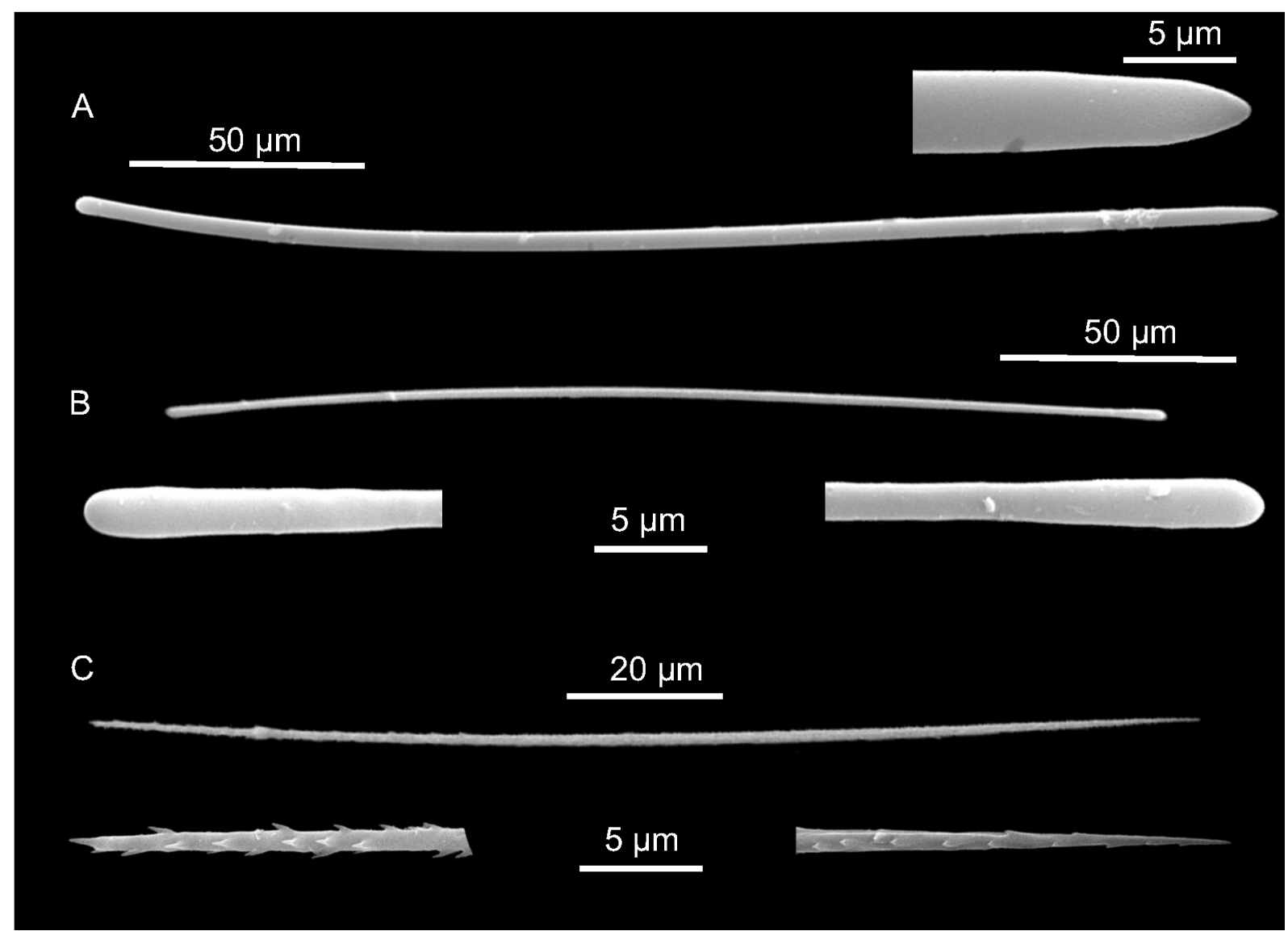

Fig. 23. Tedania sp., PdO5. A. Smooth style and magnification of the tip. B. Slightly curved tylote and magnification of the smooth tips. C. Onychaete and magnification of the tips. 


\section{Material examined}

PONTA DO OURO -1 fragment with some fistules and the basal portion, about $2 \times 1 \times 1 \mathrm{~cm}$;

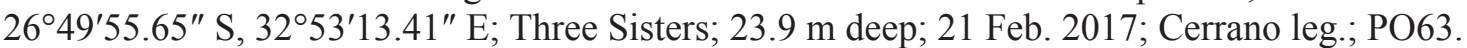

\section{Description}

The sponge is burrowed under the sediment and only its erect fistules are visible (Fig. 24A). These are whitish, transparent, showing the yellow, internal axis. The alcohol preserved sample is a thin massive base bearing fistules; the color is dirty white. The consistence is really soft and extremely compressible.

SKELETON. The skeleton of the basal part consists of multispicular tracts in confusion and grains of sediment (Fig. 24B). The skeleton of fistules (Fig. 24C) has a central axis of densely packed spicules, about $100 \mu \mathrm{m}$ in section, close to the base, and gradually thinner towards the apex of the fistula. From the axis, multispicular fibers, $20-25 \mu \mathrm{m}$ in section, develop, opening in fans close to the surface (Fig. 24C).

Spicules. The styles are in a wide range of shapes (straight, slightly curved, sinuous) and size, 285$(351.5,63.7)-495 \mu \mathrm{m} \times 5-(8.3,1.5)-10 \mu \mathrm{m}$ (Fig. 24 D-E).

\section{Remarks}

The presence on the surface of numerous finger-shaped and transparent fistulae with a central axis and the general structure of the skeleton are typical features of the genus Ciocalypta Bowerbank, 1862. To date, there are 26 species of Ciocalypta described (Van Soest et al. 2019). The specimen shares with Ciocalypta heterostyla Hentschel, 1912 the spicule size and shape, the skeleton organization and the
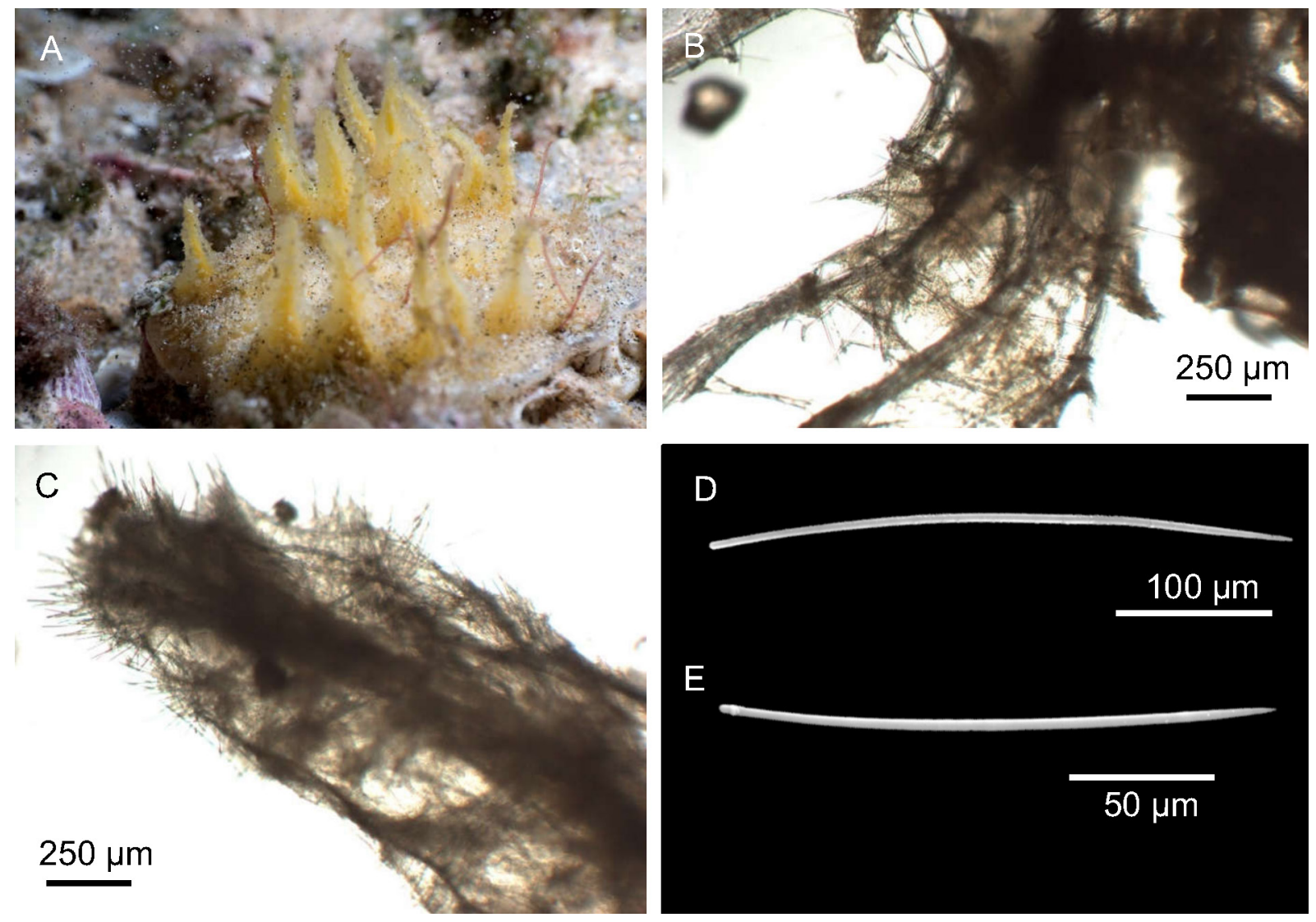

Fig. 24. Ciocalypta heterostyla Hentschel, 1912. A. Fistules erect, coming out the sediment (PO63). B. Skeleton of the basal part. C. Skeleton of fistules. D-E. Styles. 
general morphology. This species is known from Indonesia and Arafura Sea (Van Soest et al. 2019) and, therefore, this is the first record for the Indian Ocean.

Ciocalypta tyleri Bowerbank, 1873

Fig. 25

Ciocalypta tyleri Bowerbank, 1873: 21, pl. 4.

\section{Material examined}

PONTA DO OURO -1 dried sponge portion, with fistules, about $3 \times 3 \times 2 \mathrm{~cm} ; 26^{\circ} 49^{\prime} 29.579^{\prime \prime} \mathrm{S}$, 3253'51.035" E; Blacks; 18 m deep; 13 Nov. 2015; Cerrano leg.; PdO16.

\section{Description}

The sponge is massive, partially burrowing, with light yellow fistules (Fig. 25A) rising above the sediment. The dried sample is whitish, the body is rich in sediment, while the fistules are erect and fragile, with a rough surface.

SKELETON. In the body, it is formed by a confused reticulation, with loose tracts of oxeas (Fig. 25B). The fistules have a central axis of loose-packed oxeas from where tracts of spicules radiate towards the surface.

Spicules. One size, $295-(351,32.6)-400 \mu \mathrm{m} \times 5.1-(7.8,1.3)-9.5 \mu \mathrm{m}$, of curved oxeas, sometimes bent in the middle (Fig. 25C).
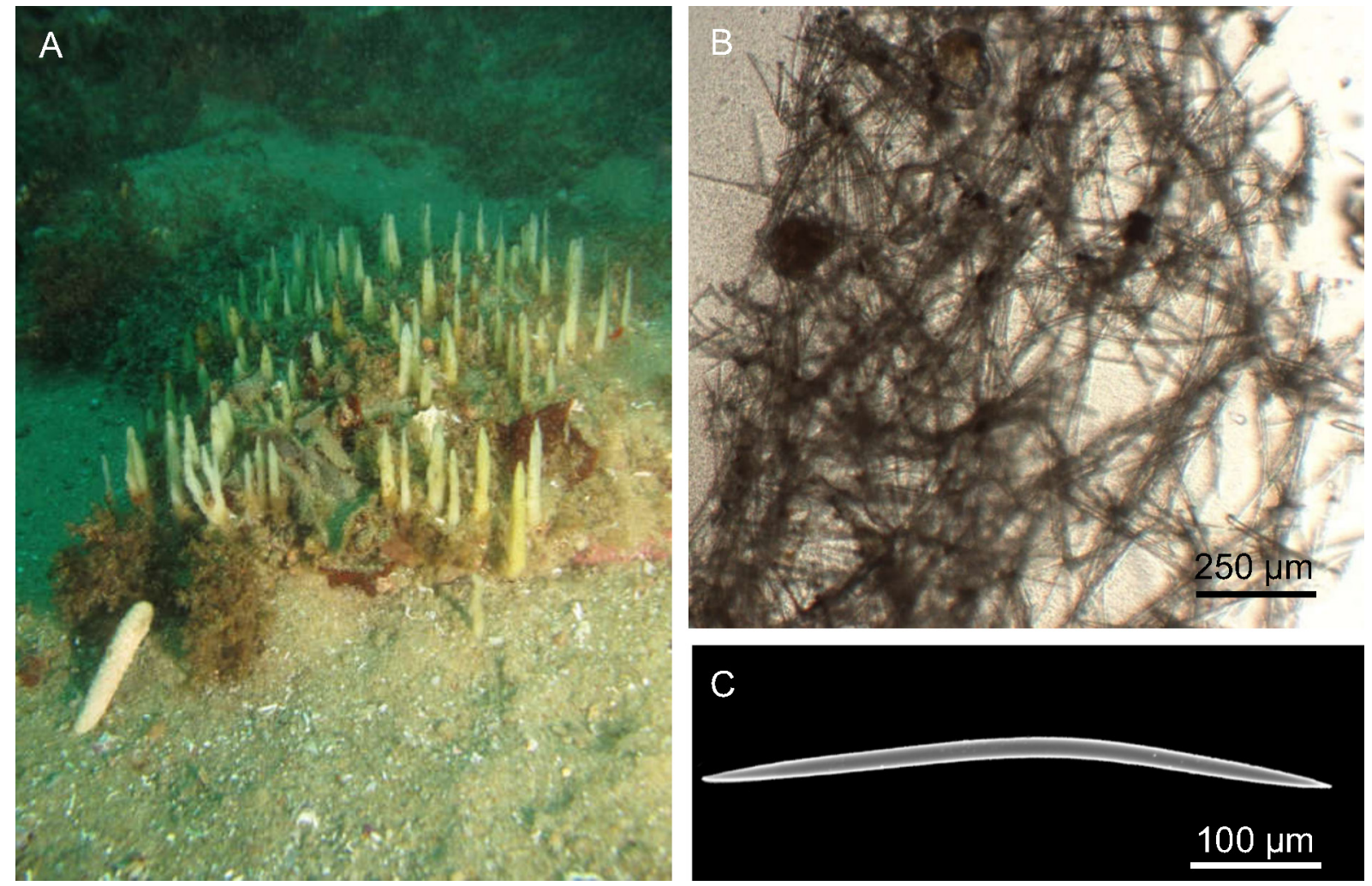

Fig. 25. Ciocalypta tyleri Bowerbank, 1873. A. Fistules erect coming out the sediment (PdO16). B. Skeleton of the basal part. C. Curved oxea. 


\section{Remarks}

The presence of numerous finger-shaped and transparent fistulae with a central axis and the general structure of the skeleton characterize the genus Ciocalypta Bowerbank, 1862. To date, there are 26 species of Ciocalypta described (Van Soest et al. 2019). The examined sample fits the original description of Ciocalypta tyleri Bowerbank, 1873 from Port Elizabeth, South Africa, in the general structure and the spicule sizes.

Family Suberitidae Schmidt, 1870

Genus Terpios Duchassing \& Michelotti, 1864

Terpios granulosus Bergquist, 1967

Fig. 26

Terpios granulosa Bergquist, 1967: 168, fig. 5.

\section{Material examined}

PONTA DO OURO - 1 sample growing on a Carijoa colony about $6 \mathrm{~cm}$ long; 26 $46^{\prime} 55.65^{\prime \prime} \mathrm{S}$, 3254'13.41" E; Three Sisters; 25.7 m deep; 8 Apr. 2017; Cerrano leg.; PO96.
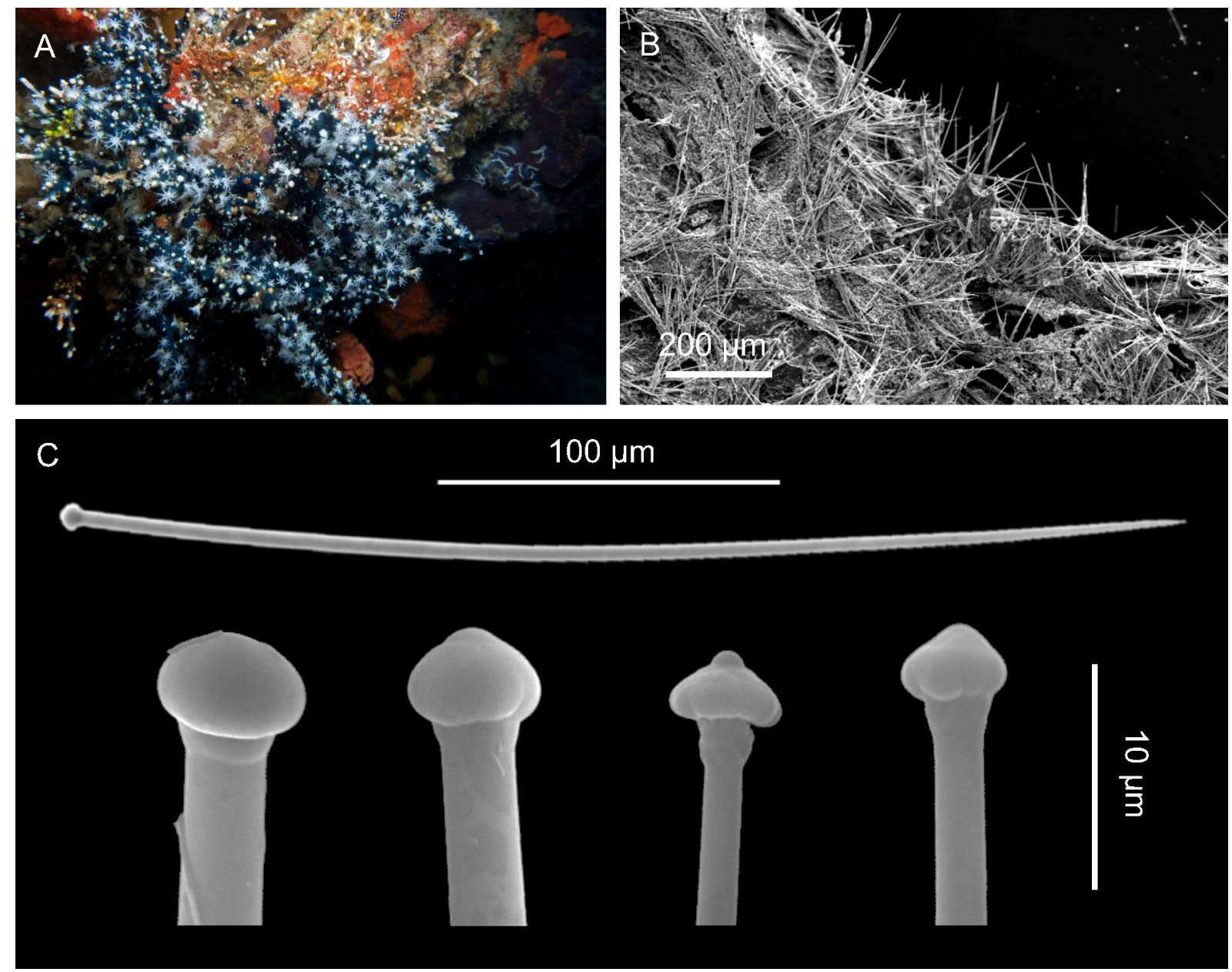

Fig. 26. Terpios granulosus Bergquist, 1967. A. Sponge (PO96) encrusting the octocoral Carijoa sp. B. Tylostyles organized in brushes (SEM). C. Tylostyle and magnification of heads, different in shape. 


\section{Description}

Thin encrusting sponge, dark blue colored; it covers colonies of the octocoral Carijoa sp. (Class Anthozoa, Phylum Cnidaria) (Fig. 26A). Whitish in ethanol, bluish in formalin. The surface is microhispid.

SKELETON. It is formed by brushes of spicules which, projecting also over the surface, cause the microhispid surface (Fig. 26B).

Spicules. Tylostyles with heads variable in shape, from mushroom-shape to plurilobate (Fig. 26C). The size is $77.5-(255,81.7)-330 \mu \mathrm{m} \times 1.25-(4.1,0.9)-5 \mu \mathrm{m}$.

\section{Remarks}

The peculiar shape of the heads, the general morphology and the skeletal structure are typical characters of species in the genus Terpios Duchassaing \& Michelotti, 1864. The specimen fits the description of Terpios granulosus (Bergquist, 1967) from Hawaii later also recorded by Vacelet \& Vasseur (1971) and Barnes \& Bell (2002) from Kenya and Madagascar.

Order Tethyida Morrow \& Cárdenas, 2015

Family Hemiasterellidae Lendenfeld, 1889

Genus Hemiasterella Carter, 1879

Hemiasterella complicata Topsent, 1919

Fig. 27

Hemiasterella complicata Topsent, 1919: 7, figs 2-5.

\section{Material examined}

PONTA DO OURO $\bullet 1$ single, dried fragment of about $4 \times 3 \mathrm{~cm} \times 8 \mathrm{~mm}$, several dried portions, 1 alcohol preserved; 264' $39.864^{\prime \prime}$ S, 3255'25.284" E; Cloud break; 34 m deep; 18 May 2015; Torsani leg.; IMG0516 • 1 fragment, alcohol preserved, of about $11 \times 5 \times 4 \mathrm{~mm} ; 26^{\circ} 50^{\prime} 36.881^{\prime \prime} \mathrm{S}, 32^{\circ} 54^{\prime} 54.478^{\prime \prime} \mathrm{E}$; Atlantis; 40.7 m deep; 6 Feb. 2017; Cerrano leg.; PO20 • 1 fragment, alcohol preserved; 26 $46^{\prime} 38.829^{\prime \prime}$ S, 3254'17.387" E; Waynes; 40.6 m deep; 17 Feb. 2017; Cerrano leg.; PO53.

\section{Description}

The sponge is lamellate, foliose; color is dark red to violet (Fig. 27A-B). On the surface, two specimens present algal turf. The samples preserved in alcohol changed color to beige; the dried samples are whitish, light brown; in the dried state, spicule tracts create an irregular pattern and thick lines on the surface. The samples have a micro-bristly surface and an elastic consistence.

SKELETON. The ectosome is constituted of a layer of densely packed euasters (Fig. 27C). the choanosome with plumo-reticulate tracts is formed by megascleres (Fig. 27D), without a well-marked differentiation between axial and extra-axial regions.

SPICULES. The megascleres are constituted by strongyloxeas and oxeas (Fig. 27E), with a wide range of intermediate forms, $590-(842.5,100.8)-980 \mu \mathrm{m} \times 10-(17.25,4.3)-25.5 \mu \mathrm{m}$; strongylasters with at least five rays (Fig. 27F) with microspined rays 7.5-(12.4, 3.6)-20 $\mu \mathrm{m}$, and smooth oxyasters 5-(8.9, 3.8) $-25 \mu \mathrm{m}$ (Fig. 27G). 

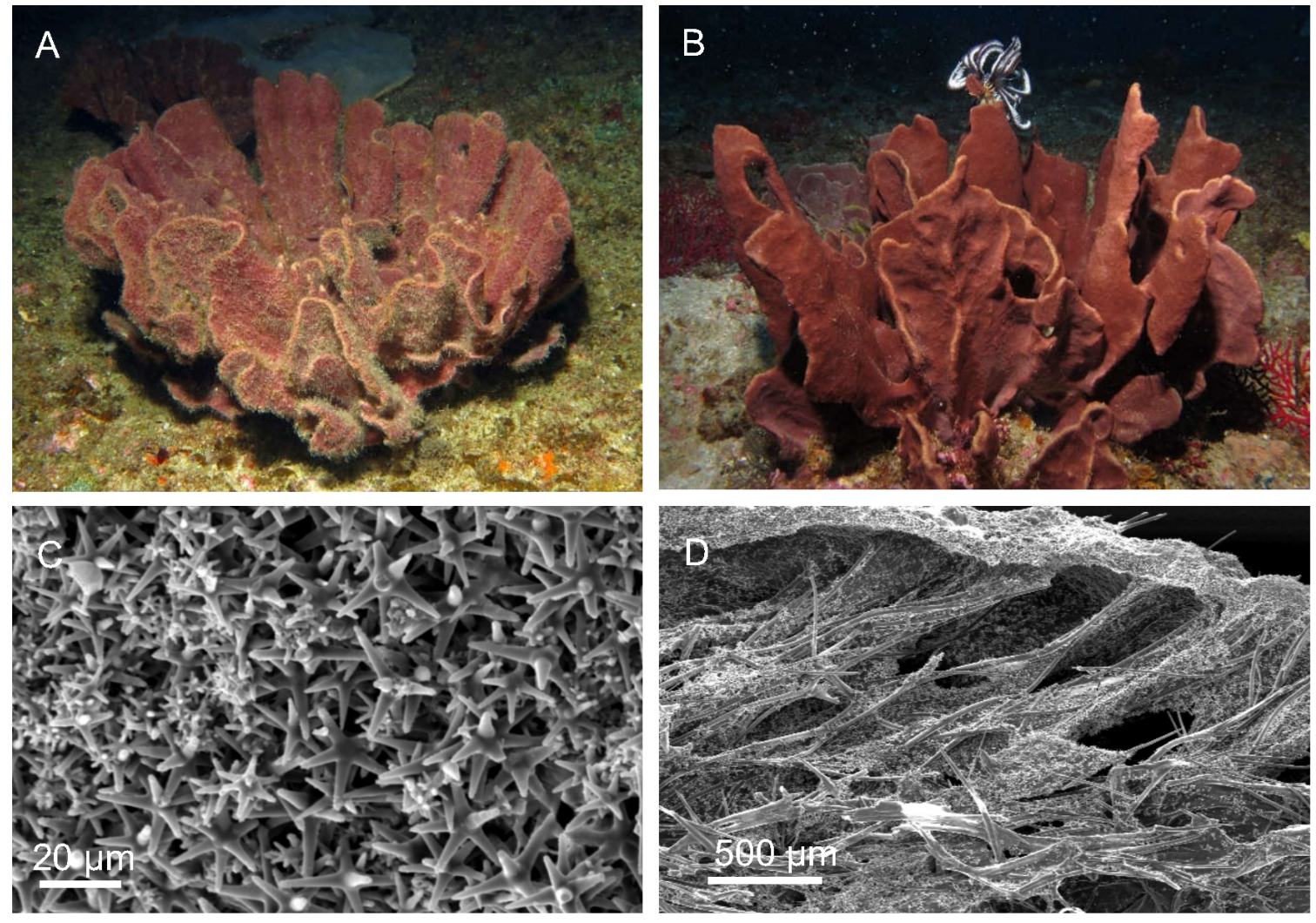

E
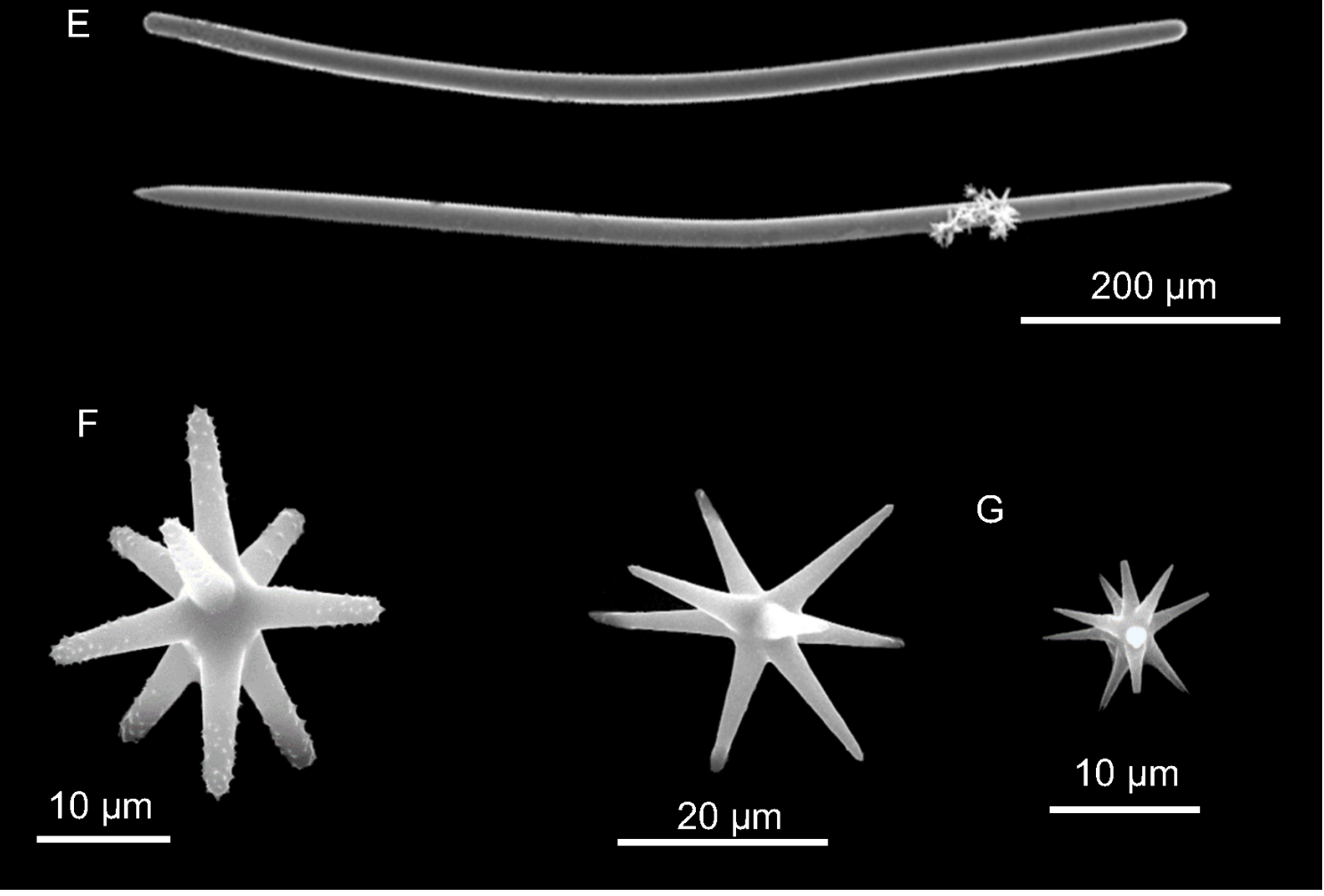

Fig. 27. Hemiasterella complicata Topsent, 1919. A. The specimen PO20 in situ. B. The specimen IMG 516. C. Ectosome constituted by densely packed euasters (SEM). D. Choanosomal skeleton (SEM). E. Strongyloxea and oxea. F. Strongylaster. G. Smooth oxyasters. 


\section{Remarks}

The examined material fits with the species Hemiasterella complicata Topsent, 1919. This is a species with a strict distribution, confined to East Africa and Madagascar (Burton 1959; Vacelet et al. 1976; Pulitzer-Finali 1993). This species is also similar to Hemiasterella vasiformis (Kirkpatrick, 1903) (Topsent 1919), recently recorded by Samaai et al. (2019) in South Africa; as a consequence, a revision of the genus Hemiasterella and a genetic analysis would be necessary in order to clarify the possible synonymy.

\section{Discussion}

The majority of species in the taxon Porifera still waits to be described, but the rate of discovery is rapidly increasing (Appeltans et al. 2012). The poor knowledge of the sponge diversity, as well as of all other marine organisms, imperils the possibility to adequately manage and preserve biodiversity, also considering the recognized role sponges play as an optimal habitat for many associated taxa (Cerrano et al. 2006; Wulff 2012), offering food and shelter during critical phases of the life cycle of several species. A baseline knowledge should be the first step for monitoring biodiversity and preventing its decline or modification. On that note, this paper represents an important contribution to the knowledge of the sponge fauna of Mozambique; other dated papers are related to close areas such as Madagascar (Lévi 1956, 1964; Thomas 1979; Vacelet \& Vasseur 1965, 1971; Vacelet et al. 1976) and East Africa (Pulitzer-Finali 1993), while a single study on the sponge diversity was conducted in North and South Mozambique by Barnes \& Bell (2002). With respect to the latter paper, out of 68 species recorded from North and 37 from South Mozambique (80 species considering the two stations), only one, Spheciospongia vagabunda (Ridley, 1884), has been recorded in Ponta do Ouro. The area of sampling has unique environmental features and belongs to the Western Indo-Pacific Province (Spalding et al. 2007), it is characterized by a high diversity and level of endemism (e.g., about $14 \%$ of fish, Briggs \& Bowen 2012); our results reflect this diversity as, out of a total of 26 species of sponges described in Ponta do Ouro, four are new to science.

Ponta do Ouro is actually a transitional zone, located between the tropical Delagoa and the temperate Natal ecoregions. This particular geographical location is reflected in the high level of diversity, in the typical Indo-Pacific tropical species and in records formally belonging to the temperate Province (i.e., Agulhas), as we have detected. The coral reef present in the studied area has been characterized through orthomosaics techniques (Palma et al. 2017) and shows a general, low level of complexity, mainly in relation to the high energy of ocean waves that affects the size and shapes of coral colonies (Palma et al. 2019). The sponge assemblages can host huge specimens such as Cliona grandis Samaai et al., 2019, showing patterns of growth clearly related to the main direction of water movement.

In the present study, eight species (Pseudoceratina purpurea, Oceanapia ramsayi, Myrmekioderma granulatum, Theonella conica, Spheciospongia vagabunda, Chondropsis lamella, Clathria (Thalysias) vulpina and Terpios granulosus are widespread in the Indo-Pacific, as well as four other diffused species (Chondrosia corticata; Callyspongia (Cladochalina) aerizusa; Clathria (Thalysias) hirsuta, 1993 and Ciocalypta heterostyla that are, however, new records for the Indian Ocean. Ciocalypta tyleri (described for South Africa, Port Elizabeth) and four species recently described for South-East Africa (Theonella timmi, Cliona grandis, Spheciospongia ndabazithe, Iotrochota cf. sinki) confirm the value of the transitional zone of the studied area.

\section{Acknowledgments}

This research has been partially funded by the EU's H2020 research and innovation programme under the Marie Sklodowska-Curie grant agreement no 643712 ("Green Bubbles"). The authors wish to thank Dr Marco Bertolino, University of Genova, Italy, for the loan of Pulitzer's personal collection as well as Jenny Strömvoll and Rupert Cornelius (Back to Basics Adventures) for logistic support and enthusiasm. 


\section{References}

Appeltans W. et al. 2012. The magnitude of global marine species diversity. Current Biology 22: 21892202. https://doi.org/10.1016/j.cub.2012.09.036

Barnes D.K.A. \& Bell J.J. 2002. Coastal sponge communities of the West Indian Ocean: morphological, richness and diversity. African Journal of Ecology 40: 350-359.

https://doi.org/10.1046/j.1365-2028.2002.00388.x

Benayahu Y. \& Shlagman M.H.S. 2003. Corals of the South-West Indian Ocean: VI. The Alcyonacea (Octocorallia) of Mozambique, with a discussion on soft coral distribution on south equatorial East African reefs. Zoologische Verhandelingen 345: 49-57.

Bensemhoun J., Bombarda I., Aknin M., Faure R., Vacelet J. \& Gaydou E.M. 2008. Marine bifunctional sphingolipids from the sponge Oceanapia ramsayi. Molecules 13 (4): 772-778.

https://doi.org/10.3390/molecules13040772

Bergquist P.R. 1965. The Sponges of Micronesia, Part I. The Palau Archipelago. Pacific Science 19 (2): 123-204.

Bergquist P.R. 1967. Additions to the sponge fauna of the Hawaiian Islands. Micronesica 3 (2): 159-174.

Bowerbank J.S. 1873. Contributions to a General History of the Spongiadae. Part IV. Proceedings of the Zoological Society of London 1873: 3-25.

Briggs J.C. \& Bowen B.W. 2012. A realignment of marine biogeographic provinces with particular reference to fish distributions. Journal of Biogeography 39: 12-30.

https://doi.org/10.1111/j.1365-2699.2011.02613.x

Burton M. 1959. Sponges. In: Scientific Reports. John Murray Expedition 1933-34. 10 (5): 151-281. Trustees of the British Museum (Natural History), London.

Available from https://www.biodiversitylibrary.org/page/49512735 [accessed 9 Jul. 2020].

Carter H.J. 1880. Report on specimens dredged up from the Gulf of Manaar and presented to the Liverpool Free Museum by Capt. W.H. Cawne Warren. Annals and Magazine of Natural History (5) 6 (31): 35-61.

Cerrano C., Calcinai B., Pinca S. \& Bavestrello G. 2006. Reef sponges as hosts of biodiversity: cases from North Sulawesi. In: Suzuki Y., Nakamori T., Hidaka M., Kayanne H., Casareto B.E., Nadao K., Yamano H. \& Tsuchiya M. (eds) $X^{\text {th }}$ Coral Reef Symposium: 208-213. Okinawa.

Cook S. de C. \& Bergquist P.R. 2002. Family Spongiidae Gray, 1867. In: Hooper J.N.A. \& Van Soest R.W.M. (eds) Systema Porifera. A Guide to the Classification of Sponges 1: 1051-1060. Kluwer Academic/Plenum Publishers, New York.

Daly C.A.K., Fraser G. \& Snowball J.D. 2013. Willingness to pay for marine-based tourism in the Ponta do Ouro Partial Marine Reserve, Mozambique. African Journal of Marine Science 37: 33-40. https://doi.org/10.2989/1814232X.2015.1012556

Dendy A. 1905. Report on the sponges collected by Professor Herdman, at Ceylon, in 1902. In: Herdman W.A. (ed) Report to the Government of Ceylon on the Pearl Oyster Fisheries of the Gulf of Manaar 3: 57-246.

Desqueyroux-Faúndez R. 1984. Description de la faune des Haplosclerida (Porifera) de la Nouvelle-Calédonie. I. Niphatidae-Callyspongiidae. Revue suisse de Zoologie 91 (3): 765-827. https://doi.org/10.5962/bhl.part.81580

Desqueyroux-Faúndez R. \& Valentine C. 2002a. Family Callyspongiidae de Laubenfels, 1936. In: Hooper J.N.A. \& Van Soest R.W.M. (eds) Systema Porifera. A Guide to the Classification of Sponges 1: 835-851. Kluwer Academic / Plenum Publishers, New York. 
Desqueyroux-Faúndez R. \& Valentine C. 2002b. Family Niphatidae Van Soest, 1980. In: Hooper J.N.A. \& Van Soest R.W.M. (eds) Systema Porifera. A Guide to the Classification of Sponges 1: 874890. Kluwer Academic/Plenum Publishers, New York.

Desqueyroux-Faúndez R. \& Van Soest R.W.M. 1996. A review of Iophonidae, Myxillidae and Tedaniidae occurring in the South East Pacific (Porifera: Poecilosclerida). Revue suisse de Zoologie 103 (1): 3-79. https://doi.org/10.5962/bhl.part.79938

Esper E.J.C. 1829. Die Pflanzenthiere in Abbildungen nach der Natur mit Farben erleuchtet, nebst Beschreibungen. Dritter Theil. Raspe, Nürnberg.

Guerreiro J., Chircop A., Dzidzornu D., Grilo C., Ribeiro R., Van Der Elst R. \& Viras A. 2011. The role of international environmental instruments in enhancing transboundary marine protected areas: An approach in East Africa. Marine Policy 35: 95-104. https://doi.org/10.1016/j.marpol.2010.06.013

Hallmann E.F. 1914. A revision of the monaxonid species described as new in Lendenfeld's Catalogue of the Sponges in the Australian Museum. Part I. Proceedings of the Linnean Society of New South Wales 39: 263-315. https://doi.org/10.5962/bhl.part.2281

Hallmann E.F. 1914. A revision of the monaxonid species described as new in Lendenfeld's Catalogue of the Sponges in the Australian Museum. Part II. Proceedings of the Linnean Society of New South Wales 39: 327-376. https://doi.org/10.5962/bhl.part.2283

Hallmann E.F. 1914. A revision of the monaxonid species described as new in Lendenfeld's Catalogue of the Sponges in the Australian Museum. Part III. Proceedings of the Linnean Society of New South Wales 39: 398-446.

Available from https://www.biodiversitylibrary.org/page/6382433 [accessed 9 Jul. 2020].

Hentschel E. 1912. Kiesel- und Hornschwämme der Aru- und Kei-Inseln. Abhandlungen herausgegeben von der Senckenbergischen naturforschenden Gesellschaft 34 (3): 293-448.

Hooper J.N.A. 2000. Sponguide. Guide to Sponge Collection and Identification. Available from https://www.qm.qld.gov.au/Find+out+about/Animals + of + Queensland/Sea + Life/Sponges/Online + resources [accessed 28 Jul. 2020].

Hooper J.N.A. 2002. Family Desmoxyidae Hallmann, 1916. In: Hooper J.N.A. \& Van Soest R.W.M. (eds) Systema Porifera. A Guide to the Classification of Sponges. Volume 1: 755-772. Kluwer Academic/Plenum Publishers, New York/Boston/Dordrecht/London/Moscow.

Hooper J.N.A. \& Lévi C. 1993. Poecilosclerida (Porifera: Demospongiae) from the New Caledonia Lagoon. Invertebrate Taxonomy 7 (5): 1221-1302.

Hooper J.N.A. \& Van Soest R.W.M. 2002. Systema Porifera: A Guide to the Classification of Sponges. Kluwer Academic/ Plenum Publishers, New York.

Ilan M., Gugel J. \& Van Soest R.W.M. 2004. Taxonomy, reproduction and ecology of new and known Red Sea sponges. Sarsia 89: 388-410. https://doi.org/10.1080/00364820410002659

Keller C. 1889. Die Spongienfauna des rothen Meeres (I. Hälfte). Zeitschrift für wissenschaftliche Zoologie 48: 311-405.

Kieschnick O. 1896. Silicispongiae von Ternate nach den Sammlungen von Herrn Prof. Dr. W. Kükenthal. Zoologischer Anzeiger 19: 526-534.

Lamarck de J.-B. 1814. Sur les polypiers empâtés. Annales du Museum national d'histoire naturelle 20: 294-312; 370-386; 432-458.

Lazoski C., Solé-Cava A., Boury-Esnault N., Klautau M. \& Russo C. 2001. Cryptic speciation in a high gene flow scenario in the oviparous marine sponge Chondrosia reniformis. Marine Biology 139 (3): 421-429. 
Lendenfeld von R. 1888. Descriptive Catalogue of the Sponges in the Australian Museum: 188. Taylor \& Francis, Sidney, London.

Lendenfeld von R. 1889. A Monograph of the Horny Sponges. Trübner and Co., London.

Lévi C. 1956. Spongiaires des côtes de Madagascar. Mémoires de I'Institut scientifique de Madagascar (A) 10: 1-23.

Lévi C. 1958. Résultats scientifiques des campagnes de la 'Calypso'. Campagne 1951-1952 en Mer Rouge (suite). 11. Spongiaires de Mer Rouge recueillis par la 'Calypso' (1951-1952). Annales de l'Institut océanographique 34 (3): 3-46.

Lévi C. 1964. Spongiaires du canal de Mozambique. Bulletin du Museum national d'histoire naturelle (2) 36 (3): 384-395.

Morrow C. \& Cárdenas P. 2015. Proposal for a revised classification of the Demospongiae (Porifera). Frontiers in Zoology 12: 7. https://doi.org/10.1186/s12983-015-0099-8

Obura D. 2012. The diversity and biogeography of Western Indian Ocean reef-building corals. PLoS ONE 7 (9): e45013. https://doi.org/10.1371/journal.pone.0045013

Olson D. 2010. A Decade of Conservation by the Critical Ecosystem Partnership Fund 2001-2010: An Independent Evaluation of CEPF's Global Impact. Conservation Earth for the Critical Ecosystem Partnership Fund, Arlington, Virginia.

Palma M., Rivas Casado M., Pantaleo U. \& Cerrano C. 2017. High resolution orthomosaics of African coral reefs: A tool for wide-scale benthic monitoring. Remote Sensing 9: 705.

https://doi.org/10.3390/rs9070705

Palma M., Magliozzi C., Rivas Casado M., Pantaleo U., Fernandes J., Coro G., Cerrano C. \& Leinster P. 2019. Quantifying coral reef composition of recreational diving sites: a structure from motion approach at seascape scale. Remote Sensing 1 (24): 3027. https://doi.org/10.3390/rs11243027

Pereira M.A.M. 2000. Levantamento Bibliográfico da Investigação nos Recifes de Coral em Moçambique. Xai-Xai, CDS - MICOA.

Pereira M.A.M., Litulo C., Santos R., Leal M., Fernandes R.S., Tibrica Y. \& Marques da Silva I. 2014. Mozambique Marine Ecosystem Review. Final report submitted to Fondation Ensamble (December), 139. Maputo, Biodinâmica/CTV. https://doi.org/10.13140/2.1.2092.5766

Ponta do Ouro Partial Marine Reserve (PPMR). 2009. Management Plan. November 2009. Maputo Special Reserve Marine Management Component.

Pulitzer-Finali G. 1993. A collection of marine sponges from East Africa. Annali del Museo civico di Storia Naturale Giacomo Doria 89: 247-350.

Ridley S.O. 1884. Spongiida. Report on the Zoological Collections made in the Indo-Pacific Ocean during the Voyage of H.M.S. 'Alert', 1881-2: 36-482. British Museum of Natural History.

Rützler K. 1978. Sponges in coral reefs. In: Stoddard D.R. \& Johannes R.E. (eds) Coral reefs: Research Methods. Monographs on Oceanographic Methodology 5: 299-313. UNESCO, Paris.

Samaai T., Pillay R. \& Janson L. 2019. Shallow-water Demospongiae (Porifera) from Sodwana Bay, iSimangaliso Wetland Park, South Africa. Zootaxa 4587 (1): 1-85.

https://doi.org/10.11646/zootaxa.4587.1.1

Santos Neto C., Nascimento E., Cavalcanti T. \& Pinheiro U. 2018. Taxonomy of Oceanapia Norman, 1869 (Demospongiae: Haplosclerida: Phloeodictyidae) from the Brazilian coast. Zootaxa 4455 (2): 363. https://doi.org/10.11646/zootaxa.4455.2.6 
Schleyer M.H., Heikoop J.M. \& Risk M.J. 2006. A benthic survey of Aliwal Shoal and assessment of the effects of a wood pulp effluent on the reef. Marine Pollution Bulletin 52: 503-514.

https://doi.org/10.1016/j.marpolbul.2005.09.038

Spalding M.D., Fox H.E., Allen G.R., Davidson N., Ferdaña Z.A., Finlayson M. \& Robertson J. 2007. Marine ecoregions of the world: a bioregionalization of coastal and shelf areas. BioScience 57 (7): 573-583. https://doi.org/10.1641/B570707

Thiele J. 1900. Kieselschwämme von Ternate. I. Abhandlungen herausgegeben von der Senckenbergischen naturforschenden Gesellschaft 25: 19-80.

Thomas P.A. 1979. Studies on sponges of the Mozambique Channel. I. Sponges of Inhaca Island. II. Sponges of Mambone and Paradise Islands. Annales du Musee royal de l'Afrique centrale 8: 1-73.

Topsent E. 1919. Notes sur les genres Semisuberites et Hemiasterella. Bulletin de l'Institut océanographique, Monaco 359: 1-11.

Vacelet J. \& Vasseur P. 1965. Spongiaires des grottes et surplombs des récifs de Tulear (Madagascar). Recueil des Travaux de la Station marine d'Endoume 2-4: 71-123.

Vacelet J. \& Vasseur P. 1971. Éponges des récifs coralliens de Tuléar (Madagascar). Tethys, Supplement 1: 51-126.

Vacelet J., Vasseur P. \& Levi C. 1976. Spongiaires de la pente externe des récifs coralliens de Tulear (Sud-Ouest de Madagascar). Mémoires du Museum national d'histoire naturelle (A, Zoologie) 49: 1-116.

Van Soest R.W.M. 2002. Family Chondropsidae Carter, 1886. In: Hooper J.N.A. \& Van Soest R.W.M. (eds) Systema Porifera. A Guide to the Classification of Sponges. Volume 1: 521-527. Kluwer Academic/ Plenum Publishers, New York.

Van Soest R.W.M., Boury-Esnault N., Hooper J.N.A., Rützler K., de Voogd N.J., Alvarez B., Hajdu E., Pisera A.B., Manconi R., Schönberg C., Klautau M., Kelly M., Vacelet J., Dohrmann M., Díaz M.C., Cárdenas P., Carballo J.L., Ríos P., Downey R. \& Morrow C.C. 2019. World Porifera Database. https://doi.org/10.14284/359

Van Soest R.W.M., Hooper J.N.A. \& Butler P.J. 2020. Every sponge its own name: removing Porifera homonyms. Zootaxa 4745 (1): 1-93.

Wulff J.L. 2012. Ecological interactions and the distribution, abundance, and diversity of sponges. In: Becerro M.A., Uriz M.J., Maldonado M. \& Turon X. (eds) Advances in Marine Biology. Vol. 61: Advances in Sponge Science: Phylogeny, Systematics, Ecology: 273-344.

https://doi.org/10.1016/B978-0-12-387787-1.00003-9

Manuscript received: 13 January 2020

Manuscript accepted: 10 June 2020

Published on: 7 August 2020

Topic editor: Rudy Jocqué

Desk editor: Kristiaan Hoedemakers

Printed versions of all papers are also deposited in the libraries of the institutes that are members of the EJT consortium: Muséum national d'histoire naturelle, Paris, France; Meise Botanic Garden, Belgium; Royal Museum for Central Africa, Tervuren, Belgium; Royal Belgian Institute of Natural Sciences, Brussels, Belgium; Natural History Museum of Denmark, Copenhagen, Denmark; Naturalis Biodiversity Center, Leiden, the Netherlands; Museo Nacional de Ciencias Naturales-CSIC, Madrid, Spain; Real Jardín Botánico de Madrid CSIC, Spain; Zoological Research Museum Alexander Koenig, Bonn, Germany; National Museum, Prague, Czech Republic. 
Appendix (continued on next two pages).

List of the identified species, with collection code as well as data about sampling and conservation status.

\begin{tabular}{|c|c|c|c|c|c|c|}
\hline Species & Code & $\begin{array}{c}\text { Date of } \\
\text { sampling }\end{array}$ & Site & Coordinates & Depth (m) & Conservation \\
\hline Hyattella pedunculata & IMG0514 & 18 May 15 & Cloud break & $\begin{array}{l}26^{\circ} 46^{\prime} 39.864^{\prime \prime} \mathrm{S} \\
32^{\circ} 55^{\prime} 25.247^{\prime \prime} \mathrm{E}\end{array}$ & 34 & dried \\
\hline Hemiasterella complicata & IMG0516 & 18 May 15 & Cloud break & $\begin{array}{l}26^{\circ} 46^{\prime} 39.864^{\prime \prime} \mathrm{S} \\
32^{\circ} 55^{\prime} 25.284^{\prime \prime} \mathrm{E}\end{array}$ & 34 & dried \\
\hline Clathria (Thalysias) vulpina & IMG0826 & 22 May 15 & Cloud break & $\begin{array}{l}26^{\circ} 46^{\prime} 39.864^{\prime \prime} \mathrm{S} \\
32^{\circ} 55^{\prime} 25.319^{\prime \prime} \mathrm{E}\end{array}$ & 36 & dried \\
\hline $\begin{array}{l}\text { Callyspongia (Callyspongia) } \\
\text { pulitzeri }\end{array}$ & IMG0827 & 22 May 15 & Cloud break & $\begin{array}{l}26^{\circ} 46^{\prime} 39.864^{\prime \prime} \mathrm{S} \\
32^{\circ} 55^{\prime} 25.355^{\prime \prime} \mathrm{E}\end{array}$ & 36 & dried \\
\hline Cliona grandis & IMG0830 & 22 May 15 & Cloud break & $\begin{array}{l}26^{\circ} 46^{\prime} 39.864^{\prime \prime} \mathrm{S} \\
32^{\circ} 55^{\prime} 25.392^{\prime \prime} \mathrm{E}\end{array}$ & 36 & dried \\
\hline Cliona grandis & IMG0913 & 24 May 15 & Blacks & $\begin{array}{l}26^{\circ} 49^{\prime} 29.579^{\prime \prime} \mathrm{S} \\
32^{\circ} 53^{\prime} 50.819^{\prime \prime} \mathrm{E}\end{array}$ & 18 & dried \\
\hline Cliona grandis & Pd02 & 11 Nov. 15 & Blacks & $\begin{array}{l}26^{\circ} 49^{\prime} 29.579^{\prime \prime} \mathrm{S} \\
32^{\circ} 53^{\prime} 50.819^{\prime \prime} \mathrm{E}\end{array}$ & 17 & dried \\
\hline Tedania sp. & $\mathrm{PdO} 5$ & 11 Nov. 15 & Blacks & $\begin{array}{l}26^{\circ} 49^{\prime} 29.579^{\prime \prime} \mathrm{S} \\
32^{\circ} 53^{\prime} 50.891^{\prime \prime} \mathrm{E}\end{array}$ & 17 & dried \\
\hline Spheciospongia vagabunda & $\mathrm{PdO} 14$ & 13 Nov. 15 & Blacks & $\begin{array}{l}26^{\circ} 49^{\prime} 29.579^{\prime \prime} \mathrm{S} \\
32^{\circ} 53^{\prime} 50.891^{\prime \prime} \mathrm{E}\end{array}$ & 18 & dried \\
\hline Ciocalypta tyleri & $\mathrm{PdO} 16$ & 13 Nov. 15 & Blacks & $\begin{array}{l}26^{\circ} 49^{\prime} 29.579^{\prime \prime} \mathrm{S} \\
32^{\circ} 53^{\prime} 51.035^{\prime \prime} \mathrm{E}\end{array}$ & 18 & dried \\
\hline Theonella timmi & $\mathrm{PdO} 17$ & 13 Nov. 15 & Blacks & $\begin{array}{l}26^{\circ} 49^{\prime} 29.579^{\prime \prime} \mathrm{S} \\
32^{\circ} 53^{\prime} 51.072^{\prime \prime} \mathrm{E}\end{array}$ & 18 & dried \\
\hline $\begin{array}{l}\text { Callyspongia (Cladochalina) } \\
\text { aerizusa }\end{array}$ & PdO18a & 14 Nov. 15 & Doodles & $\begin{array}{l}26^{\circ} 49^{\prime} 50.408^{\prime \prime} \mathrm{S} \\
32^{\circ} 53^{\prime} 45.97^{\prime \prime} \mathrm{E}\end{array}$ & 18 & alcohol \\
\hline $\begin{array}{l}\text { Amphimedon palmata } \\
\text { sp. nov. }\end{array}$ & $\mathrm{PdO} 18 \mathrm{~b}$ & 14 Nov. 15 & Doodles & $\begin{array}{l}26^{\circ} 49^{\prime} 50.408^{\prime \prime} \mathrm{S} \\
32^{\circ} 53^{\prime} 45.974^{\prime \prime} \mathrm{E}\end{array}$ & 18 & alcohol \\
\hline Chondropsis lamella & $\mathrm{PdO} 18 \mathrm{c}$ & 14 Nov. 15 & Doodles & $\begin{array}{l}26^{\circ} 49^{\prime} 50.408^{\prime \prime} \mathrm{S} \\
32^{\circ} 53^{\prime} 45.977^{\prime \prime} \mathrm{E}\end{array}$ & 18 & alcohol \\
\hline Cliona grandis & PdO19 & 15 Nov. 15 & Texas & $\begin{array}{l}26^{\circ} 45^{\prime} 41.04^{\prime \prime} \mathrm{S} \\
32^{\circ} 54^{\prime} 7.138^{\prime \prime} \mathrm{E}\end{array}$ & 11 & dried \\
\hline Cliona grandis & $\mathrm{PdO} 22$ & 15 Nov. 15 & Texas & $\begin{array}{l}26^{\circ} 45^{\prime} 41.04^{\prime \prime} \mathrm{S} \\
32^{\circ} 54^{\prime} 7.141^{\prime \prime} \mathrm{E}\end{array}$ & 11 & dried \\
\hline Theonella timmi & $\mathrm{PdO} 23$ & 15 Nov. 15 & Texas & $\begin{array}{l}26^{\circ} 45^{\prime} 41.04^{\prime \prime} \mathrm{S} \\
32^{\circ} 54^{\prime} 7.144^{\prime \prime} \mathrm{E}\end{array}$ & 11 & dried \\
\hline Theonella timmi & $\mathrm{PdO} 26$ & 18 Nov. 15 & Doodles & $\begin{array}{l}26^{\circ} 49^{\prime} 50.408^{\prime \prime} \mathrm{S} \\
32^{\circ} 53^{\prime} 45.974^{\prime \prime} \mathrm{E}\end{array}$ & 18 & dried \\
\hline Oceanapia ramsayi & $\mathrm{PdO} 27$ & 20 Nov. 15 & Kev's & $\begin{array}{l}26^{\circ} 49^{\prime} 17.512^{\prime \prime} \mathrm{S} \\
32^{\circ} 53^{\prime} 42.5^{\prime \prime} \mathrm{E}\end{array}$ & 17 & dried \\
\hline
\end{tabular}


Appendix (continued).

\begin{tabular}{|c|c|c|c|c|c|c|}
\hline Species & Code & $\begin{array}{c}\text { Date of } \\
\text { sampling }\end{array}$ & Site & Coordinates & Depth (m) & Conservation \\
\hline Oceanapia ramsayi & $\mathrm{PdO} 28$ & 20 Nov. 15 & Kev's & $\begin{array}{l}26^{\circ} 49^{\prime} 17.512^{\prime \prime} \mathrm{S} \\
32^{\circ} 53^{\prime} 42.503^{\prime \prime} \mathrm{E}\end{array}$ & 17 & dried \\
\hline Theonella conica & PO02 & 3 Feb. 17 & Kev's & $\begin{array}{l}26^{\circ} 49^{\prime} 17.512^{\prime \prime} \mathrm{S} \\
32^{\circ} 53^{\prime} 42.507^{\prime \prime} \mathrm{E}\end{array}$ & 23.4 & dried \\
\hline Clathria (Thalysias) vulpina & PO03 & 3 Feb. 17 & Kev's & $\begin{array}{l}26^{\circ} 49^{\prime} 17.512^{\prime \prime} \mathrm{S} \\
32^{\circ} 53^{\prime} 42.511^{\prime \prime} \mathrm{E}\end{array}$ & 23.4 & dried \\
\hline Pseudoceratina purpurea & PO04 & 3 Feb. 17 & Kev's & $\begin{array}{l}26^{\circ} 49^{\prime} 17.512^{\prime \prime} \mathrm{S} \\
32^{\circ} 53^{\prime} 42.514^{\prime \prime} \mathrm{E}\end{array}$ & 23.4 & alcohol \\
\hline $\begin{array}{l}\text { Callyspongia (Euplacella) } \\
\text { abnormis }\end{array}$ & PO05 & 3 Feb. 17 & Kev's & $\begin{array}{l}26^{\circ} 49^{\prime} 17.512^{\prime \prime} \mathrm{S} \\
32^{\circ} 53^{\prime} 42.518^{\prime \prime} \mathrm{E}\end{array}$ & 23.4 & alcohol \\
\hline Chondrosia corticata & PO07 & 3 Feb. 17 & Kev's & $\begin{array}{l}26^{\circ} 49^{\prime} 17.512^{\prime \prime} \mathrm{S} \\
32^{\circ} 53^{\prime} 42.521^{\prime \prime} \mathrm{E}\end{array}$ & 23.4 & alcohol \\
\hline Clathria (Thalysias) hirsuta & PO10 & 4 Feb. 17 & Blacks & $\begin{array}{l}26^{\circ} 49^{\prime} 29.579^{\prime \prime} \mathrm{S} \\
32^{\circ} 53^{\prime} 51.072^{\prime \prime} \mathrm{E}\end{array}$ & 19.2 & dried \\
\hline Theonella timmi & PO18 & 6 Feb. 17 & Atlantis & $\begin{array}{l}26^{\circ} 50^{\prime} 36.881^{\prime \prime} \mathrm{S} \\
32^{\circ} 54^{\prime} 54.471^{\prime \prime} \mathrm{E}\end{array}$ & 40.7 & alcohol \\
\hline Theonella timmi & PO19 & 6 Feb. 17 & Atlantis & $\begin{array}{l}26^{\circ} 50^{\prime} 36.881^{\prime \prime} \mathrm{S} \\
32^{\circ} 54^{\prime} 54.475^{\prime \prime} \mathrm{E}\end{array}$ & 40.7 & alcohol \\
\hline Hemiasterella complicata & PO20 & 6 Feb. 17 & Atlantis & $\begin{array}{l}26^{\circ} 50^{\prime} 36.881^{\prime \prime} \mathrm{S} \\
32^{\circ} 54^{\prime} 54.478^{\prime \prime} \mathrm{E}\end{array}$ & 40.7 & alcohol \\
\hline $\begin{array}{l}\text { Phoriospongia } \\
\text { mozambiquensis sp. nov. }\end{array}$ & PO21 & 7 Feb. 17 & Doodles & $\begin{array}{l}26^{\circ} 49^{\prime} 50.408^{\prime \prime} \mathrm{S} \\
32^{\circ} 53^{\prime} 45.97^{\prime \prime} \mathrm{E}\end{array}$ & 17 & alcohol \\
\hline Cliona grandis & $\mathrm{PO} 22$ & 7 Feb. 17 & Doodles & $\begin{array}{l}26^{\circ} 49^{\prime} 50.408^{\prime \prime} \mathrm{S} \\
32^{\circ} 53^{\prime} 45.974^{\prime \prime} \mathrm{E}\end{array}$ & 17 & alcohol \\
\hline Cliona grandis & $\mathrm{PO} 23$ & 7 Feb. 17 & Doodles & $\begin{array}{l}26^{\circ} 49^{\prime} 50.408^{\prime \prime} \mathrm{S} \\
32^{\circ} 53^{\prime} 45.977^{\prime \prime} \mathrm{E}\end{array}$ & 17 & alcohol \\
\hline Cliona grandis & PO27 & 9 Feb. 17 & Close & $\begin{array}{l}26^{\circ} 49^{\prime} 50.408^{\prime \prime} \mathrm{S} \\
32^{\circ} 53^{\prime} 57.659^{\prime \prime} \mathrm{E}\end{array}$ & 18.6 & alcohol \\
\hline Theonella conica & PO29 & 9 Feb. 17 & Close & $\begin{array}{c}26^{\circ} 47^{\prime} 34.8^{\prime \prime} \mathrm{S} \\
32^{\circ} 53^{\prime} 57.662^{\prime \prime} \mathrm{E}\end{array}$ & 18.6 & alcohol \\
\hline $\begin{array}{l}\text { Callyspongia (Euplacella) } \\
\text { abnormis }\end{array}$ & PO30 & 9 Feb. 17 & Close & $\begin{array}{c}26^{\circ} 47^{\prime} 34.8^{\prime \prime} \mathrm{S} \\
32^{\circ} 53^{\prime} 57.665^{\prime \prime} \mathrm{E}\end{array}$ & 18.6 & alcohol \\
\hline Chondropsis lamella & PO32 & 9 Feb. 17 & Close & $\begin{array}{c}26^{\circ} 47^{\prime} 34.8^{\prime \prime} \mathrm{S} \\
32^{\circ} 53^{\prime} 57.668^{\prime \prime} \mathrm{E}\end{array}$ & 18.6 & alcohol \\
\hline Chondropsis lamella & PO33 & 9 Feb. 17 & Close & $\begin{array}{c}26^{\circ} 47^{\prime} 34.8^{\prime \prime} \mathrm{S} \\
32^{\circ} 53^{\prime} 57.671^{\prime \prime} \mathrm{E}\end{array}$ & 18.6 & alcohol \\
\hline Theonella timmi & PO34 & 11 Feb. 17 & Kev's & $\begin{array}{l}26^{\circ} 49^{\prime} 17.512^{\prime \prime} \mathrm{S} \\
32^{\circ} 53^{\prime} 42.5^{\prime \prime} \mathrm{E}\end{array}$ & 22.4 & alcohol \\
\hline
\end{tabular}


Appendix (continued).

\begin{tabular}{|c|c|c|c|c|c|c|}
\hline Species & Code & $\begin{array}{c}\text { Date of } \\
\text { sampling }\end{array}$ & Site & Coordinates & Depth (m) & Conservation \\
\hline Theonella timmi & PO35 & 11 Feb. 17 & Kev's & $\begin{array}{l}26^{\circ} 49^{\prime} 17.512^{\prime \prime} \mathrm{S} \\
32^{\circ} 53^{\prime} 42.503^{\prime \prime} \mathrm{E}\end{array}$ & 22.4 & alcohol \\
\hline Theonella timmi & PO36 & 11 Feb. 17 & Kev's & $\begin{array}{l}26^{\circ} 49^{\prime} 17.512^{\prime \prime} \mathrm{S} \\
32^{\circ} 53^{\prime} 42.507^{\prime \prime} \mathrm{E}\end{array}$ & 22.4 & alcohol \\
\hline $\begin{array}{l}\text { Hyattella pedunculata } \\
\text { sp. nov. }\end{array}$ & PO51 & 17 Feb. 17 & Waynes & $\begin{array}{l}26^{\circ} 46^{\prime} 38.829^{\prime \prime} \mathrm{S} \\
32^{\circ} 54^{\prime} 17.381^{\prime \prime} \mathrm{E}\end{array}$ & 40.6 & alcohol \\
\hline Spheciospongia ndabazithe & PO52 & 17 Feb. 17 & Waynes & $\begin{array}{l}26^{\circ} 46^{\prime} 38.829^{\prime \prime} \mathrm{S} \\
32^{\circ} 54^{\prime} 17.384^{\prime \prime} \mathrm{E}\end{array}$ & 40.6 & alcohol \\
\hline Hemiasterella complicata & PO53 & 17 Feb. 17 & Waynes & $\begin{array}{l}26^{\circ} 46^{\prime} 38.829^{\prime \prime} \mathrm{S} \\
32^{\circ} 54^{\prime} 17.387^{\prime \prime} \mathrm{E}\end{array}$ & 40.6 & alcohol \\
\hline Ciocalypta heterostyla & PO63 & 21 Feb. 17 & Three sisters & $\begin{array}{l}26^{\circ} 49^{\prime} 55.65^{\prime \prime} \mathrm{S} \\
32^{\circ} 53^{\prime} 13.41^{\prime \prime} \mathrm{E}\end{array}$ & 23.9 & alcohol \\
\hline Cliona grandis & PO64 & 21 Feb. 17 & Three sisters & $\begin{array}{l}26^{\circ} 49^{\prime} 55.65^{\prime \prime} \mathrm{S} \\
32^{\circ} 53^{\prime} 13.413^{\prime \prime} \mathrm{E}\end{array}$ & 23.9 & alcohol \\
\hline $\begin{array}{l}\text { Amphimedon } \\
\text { brevispiculifera }\end{array}$ & PO65 & 21 Feb. 17 & Three sisters & $\begin{array}{l}26^{\circ} 49^{\prime} 55.65^{\prime \prime} \mathrm{S} \\
32^{\circ} 53^{\prime} 13.417^{\prime \prime} \mathrm{E}\end{array}$ & 23.9 & alcohol \\
\hline Hyattella sulfurea sp. nov. & PO71 & 4 Mar. 17 & Atlantis & $\begin{array}{l}26^{\circ} 50^{\prime} 36.881^{\prime \prime} \mathrm{S} \\
32^{\circ} 54^{\prime} 54.471^{\prime \prime} \mathrm{E}\end{array}$ & 47.7 & alcohol \\
\hline Clathria (Thalysias) hirsuta & PO78 & 6 Mar. 17 & Tea garden & $\begin{array}{l}26^{\circ} 49^{\prime} 16.561^{\prime \prime} \mathrm{S} \\
32^{\circ} 53^{\prime} 52.979^{\prime \prime} \mathrm{E}\end{array}$ & 19.7 & alcohol \\
\hline Chondropsis lamella & PO79 & 6 Mar. 17 & Tea garden & $\begin{array}{l}26^{\circ} 49^{\prime} 55.65^{\prime \prime} \mathrm{S} \\
32^{\circ} 53^{\prime} 52.982^{\prime \prime} \mathrm{E}\end{array}$ & 19.7 & alcohol \\
\hline $\begin{array}{l}\text { Callyspongia (Cladochalina) } \\
\text { aerizusa }\end{array}$ & PO82 & 11 Mar. 17 & Kev's & $\begin{array}{l}26^{\circ} 50^{\prime} 36.881^{\prime \prime} \mathrm{S} \\
32^{\circ} 53^{\prime} 42.5^{\prime \prime} \mathrm{E}\end{array}$ & 24.1 & alcohol \\
\hline Iotrochota cf. sinki & PO85 & 14 Mar. 17 & Three Sisters & $\begin{array}{l}26^{\circ} 46^{\prime} 55.65^{\prime \prime} \mathrm{S} \\
32^{\circ} 54^{\prime} 13.41^{\prime \prime} \mathrm{E}\end{array}$ & 24.2 & alcohol \\
\hline $\begin{array}{l}\text { Callyspongia (Cladochalina) } \\
\text { aerizusa }\end{array}$ & PO86 & 14 Mar. 17 & Three sisters & $\begin{array}{l}26^{\circ} 46^{\prime} 55.65^{\prime \prime} \mathrm{S} \\
32^{\circ} 54^{\prime} 13.413^{\prime \prime} \mathrm{E}\end{array}$ & 24.2 & alcohol \\
\hline Theonella timmi & PO88 & 17 Mar. 17 & $\begin{array}{l}\text { Green } \\
\text { bubbles }\end{array}$ & $\begin{array}{l}26^{\circ} 49^{\prime} 19.119^{\prime \prime} \mathrm{S} \\
32^{\circ} 54^{\prime} 9.82^{\prime \prime} \mathrm{E}\end{array}$ & 41.5 & alcohol \\
\hline Terpios granulosus & PO96 & 8 Apr. 17 & Three sisters & $\begin{array}{l}26^{\circ} 46^{\prime} 55.65^{\prime \prime} \mathrm{S} \\
32^{\circ} 54^{\prime} 13.41^{\prime \prime} \mathrm{E}\end{array}$ & 25.7 & alcohol \\
\hline Pseudoceratina purpurea & PO97 & 12 Apr. 17 & $\begin{array}{l}\text { Jenny's } \\
\text { Paradise }\end{array}$ & $\begin{array}{l}26^{\circ} 46^{\prime} 50.336^{\prime \prime} \mathrm{S} \\
32^{\circ} 54^{\prime} 12.329^{\prime \prime} \mathrm{E}\end{array}$ & 17.8 & alcohol \\
\hline Myrmekioderma granulatum & PO98 & 20 Apr. 17 & Doodles & $\begin{array}{l}26^{\circ} 49^{\prime} 50.408^{\prime \prime} \mathrm{S} \\
32^{\circ} 53^{\prime} 45.97^{\prime \prime} \mathrm{E}\end{array}$ & 17.6 & alcohol \\
\hline Iotrochota cf. sinki & PO100 & 22 Apr. 17 & Kev's & $\begin{array}{l}26^{\circ} 49^{\prime} 17.512^{\prime \prime} \mathrm{S} \\
32^{\circ} 53^{\prime} 42.5^{\prime \prime} \mathrm{E}\end{array}$ & 26.2 & alcohol \\
\hline
\end{tabular}

